Prepared for the U.S. Department of Energy

under Contract DE-AC05-76RL01830

\title{
Transuranic Contamination in Sediment and Groundwater at the U.S. DOE Hanford Site
}

KJ Cantrell

August 2009

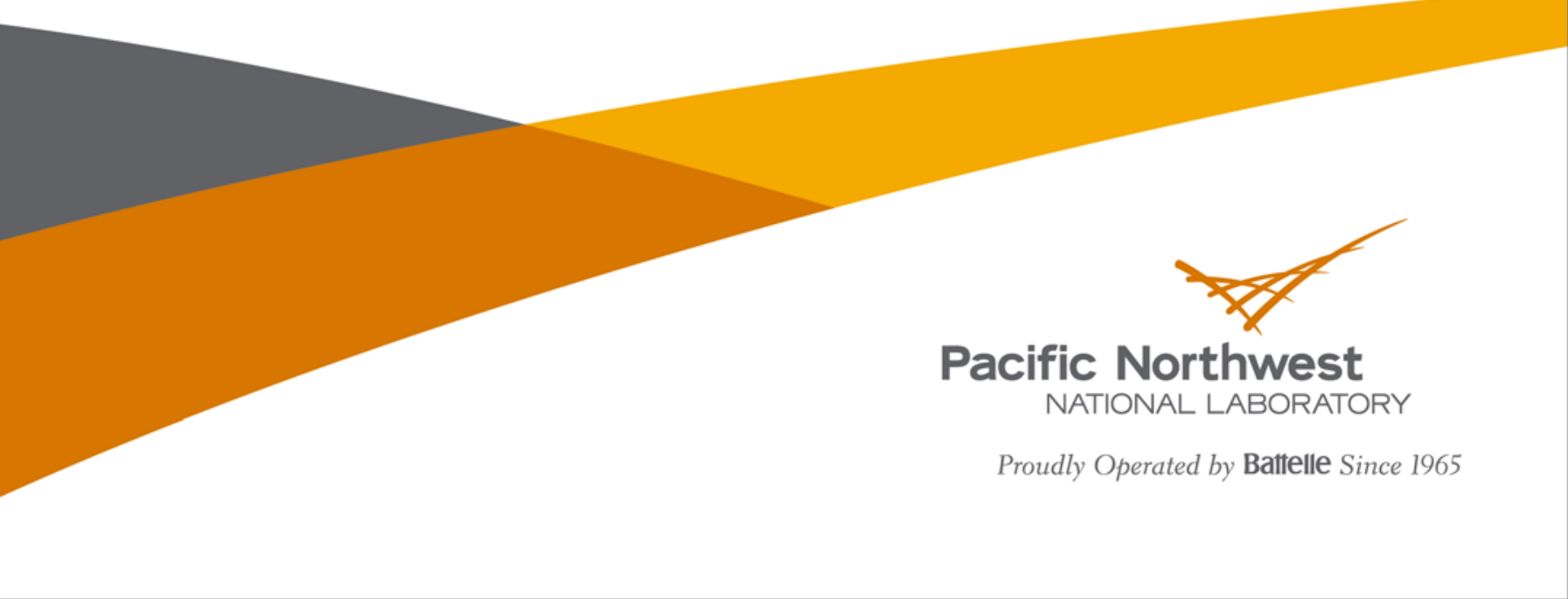




\section{Transuranic Contamination in Sediment and Groundwater at the U.S. DOE Hanford Site}

KJ Cantrell

August 2009

Prepared for the U.S. Department of Energy

under Contract DE-AC05-76RL01830

Pacific Northwest National Laboratory

Richland, Washington 99352 


\section{Summary}

This document presents a review of transuranic radionuclide contamination in sediments and groundwater at the U.S. Department of Energy (DOE) Hanford Site. The review focuses primarily on plutonium-239/240 and americium-241; however, other transuranic nuclides are discussed as well, including neptunium-237, plutonium-238, and plutonium-241. The scope of the review includes liquid process wastes intentionally disposed to constructed waste disposal facilities such as trenches, cribs, and burial grounds, as well as unplanned releases to the ground surface. The review does not include liquid wastes disposed to tanks or solid wastes disposed to burial grounds.

It is estimated that more than $11,800 \mathrm{Ci}$ of plutonium-239; $28,700 \mathrm{Ci}$ of americium-241; and $55 \mathrm{Ci}$ of neptunium-237 have been disposed as liquid waste to the near surface environment at the Hanford Site. Despite the very large quantities of transuranic contaminants disposed to the vadose zone at the site, only minuscule amounts have entered the groundwater. Currently, no wells onsite exceed the DOE-derived concentration guide for plutonium-239/240 (30 pCi/L) or any other transuranic contaminant in filtered samples. The DOE-derived concentration guide was exceeded by a small fraction in unfiltered samples from one well (299-E28-23) in recent years (35.4 and 40.4 pCi/L in fiscal year 2006). This well is located $1 \mathrm{~m}$ from the 216-B-5 Reverse Well within the B Plant zone.

The primary reason that disposal of these large quantities of transuranic radionuclides directly to the vadose zone at the Hanford Site has not resulted in widespread groundwater contamination is that under the typical oxidizing and neutral to slightly alkaline $\mathrm{pH}$ conditions of the Hanford vadose zone, transuranic radionuclides (plutonium and americium in particular) have a very low solubility and high affinity for surface adsorption to mineral surfaces common within the Hanford vadose zone. In addition, the vadose zone is typically very thick (hundreds of feet), and the net infiltration rate is very low due to the desert climate.

In some cases in which transuranic radionuclides have been co-disposed with acidic liquid waste, transport through the vadose zone for considerable distances has occurred. For example, at the 216-Z-9 Trench, plutonium-239 and americium-241 have moved to depths in excess of $36 \mathrm{~m}$ (118 ft) below ground surface. Acidic conditions and the presence of possible complexants could increase the solubility of these contaminants and reduce adsorption to mineral surfaces. Subsequent neutralization of the acidity by naturally occurring calcite in the vadose zone (particularly in the Cold Creek unit) appears to have effectively stopped further migration.

The vast majority of transuranic contaminants disposed to the vadose zone on the Hanford Site (10,200 Ci [86\%] of plutonium-239; 27,900 Ci [97\%] of americium-241; and 41.8 Ci [78\%] of neptunium-237) were disposed in sites within the Plutonium Finishing Plant closure zone. This closure zone is located within the 200 West Area. Other closure zones with notably high quantities of transuranic contaminant disposal include the T Farm zone with $408 \mathrm{Ci}$ (3.5\%) plutonium-239, the Plutonium Uranium Extraction zone with 330 Ci (2.8\%) plutonium-239, 200-W Ponds zone with 324 Ci (2.8\%) plutonium-239, B Farm zone with 183 Ci (1.6\%) plutonium-239, and the Reduction-Oxidation zone with 164 Ci (1.4\%) plutonium-239. 
Characterization studies for most of the sites reviewed in the document are generally limited. The most prevalent characterization methods used centered around geophysical logging. Characterization of a number of sites included laboratory analysis of borehole sediment samples specifically for radionuclides and other contaminants, as well as for geologic and hydrologic properties. In some instances, more detailed research-level studies were conducted.

The 216-Z-9 Trench is a case in which more detailed characterization was performed. The trenchrelated studies found that the highest concentrations of plutonium and americium below the bottom of the trench were associated with sediments of within and above silt- and clay-rich layers in the sediment profile. These results indicated that these silt- and clay-rich layers were acting as barriers to vertical migration. The trench characterization studies also found that plutonium and americium were relatively enriched within the silt and clay portion of the samples. Leaching of these sediment samples with Hanford Site groundwater indicated release of plutonium and americium from the sediments correlates most significantly with the acidity of the water and not the initial concentrations of plutonium and americium in the sediments. Only deionized water extracts that were acidic after contact with the sediments ( $\mathrm{pH} 4.3$ to 5.4) contained detectable concentrations of extractable plutonium and americium. Geochemical modeling results indicated americium in water in contact with these sediments is highly undersaturated with respect to $\mathrm{Am}(\mathrm{OH})_{3}(\mathrm{c})$ and plutonium concentrations were undersaturated with respect to $\mathrm{PuO}_{2}(\mathrm{am})$. 


\section{Acknowledgments}

The work documented in this report was supported by funding from both the U.S. Department of Energy Environmental Remediation Sciences Program (ERSP) Scientific Focus Area (SFA) and the Office of Biological and Environmental Research (BER). The author greatly appreciates the technical reviews provided by GV Last (Pacific Northwest National Laboratory [PNNL]) and Virginia Rohay (CH2M HILL Plateau Remediation Company). I am particularly grateful to AJ Currie (PNNL) for completing the editorial review and KR Neiderhiser (PNNL) for final word processing of this technical report. 


\section{Acronyms and Abbreviations}

$\begin{array}{ll}\text { bgs } & \text { below ground surface } \\ \text { CERCLA } & \text { Comprehensive Environmental Response, Compensation, and Liability Act of } \\ \text { DNAPL } & 1980 \\ \text { DOE } & \text { dense nonaqueous phase liquid } \\ \text { FY } & \text { U.S. Department of Energy } \\ \text { HDW } & \text { fiscal year } \\ \text { HEIS } & \text { Hanford Defined Waste (model) } \\ \text { KE } & \text { Hanford Environmental Information System } \\ \text { KW } & \text { K East (basin) } \\ \text { NRDWL } & \text { K West (basin) } \\ \text { PFP } & \text { nonradioactive dangerous waste landfill } \\ \text { PNNL } & \text { Plutonium Finishing Plant } \\ \text { PUREX } & \text { Pacific Northwest National Laboratory } \\ \text { RECUPLEX } & \text { Plutonium Uranium Extraction (Plant or process) } \\ \text { REDOX } & \text { Recovery of Uranium and Plutonium by Extraction (Plant or process) } \\ \text { SIM } & \text { Reduction-Oxidation (Plant or process) } \\ \text { SNF } & \text { Soil Inventory Model } \\ \text { TBP } & \text { spent nuclear fuel } \\ \text { UNH } & \text { tributyl phosphate } \\ \text { UPR } & \text { uranyl nitrate hexhydrate } \\ \text { WIDS } & \text { unplanned release } \\ & \text { Waste Information Data System } \\ & \end{array}$




\section{Units of Measure}

$\begin{array}{ll}\mathrm{Ci} & \text { curie } \\ \mathrm{ft} & \text { foot } \\ \mathrm{ft}^{3} & \text { cubic feet } \\ \mathrm{g} & \text { gram } \\ \text { gal } & \text { gallon } \\ \mathrm{L} & \text { liter } \\ \mu & \left.\text { micro (prefix, } 10^{-6}\right) \\ \mu \mathrm{Ci} & \text { microcurie }\left(10^{-6} \mathrm{Ci}\right) \\ \mathrm{m} & \text { meter } \\ \mathrm{ML} & \text { megaliter }\left(10^{6} \mathrm{~L}\right) \\ \mathrm{nCi} & \text { nanocurie }\left(10^{-9} \mathrm{Ci}\right) \\ \mathrm{pCi} & \text { picocurie }\left(10^{-12} \mathrm{Ci}\right)\end{array}$




\section{Contents}

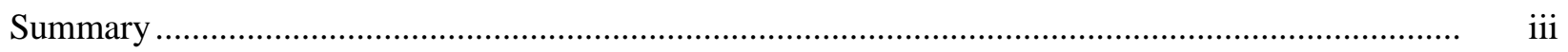

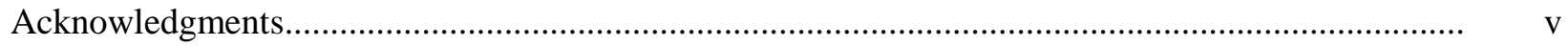

Acronyms and Abbreviations ...................................................................................................... vii

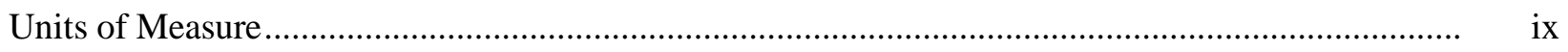

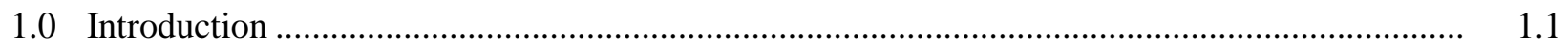

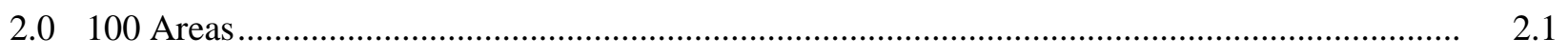

2.1 100-K Area Fuel Storage Basins.................................................................................. 2.2

2.1.1 KE Basin Leaks and Plutonium Contamination................................................ 2.2

2.1.2 Chemistry of Plutonium in Groundwater at the 100-K Area ............................... 2.3

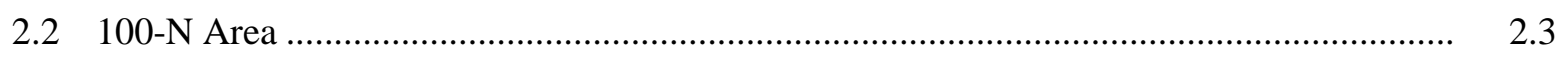

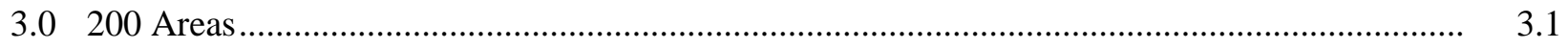

$3.1200-E$ Ponds Zone.................................................................................................. 3.5

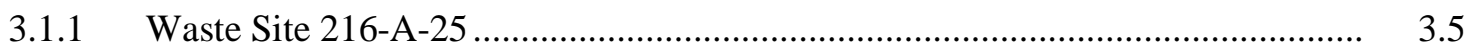

3.1.2 Waste Site 216-B-3 ...................................................................................... 3.6

3.2 200-W Ponds Zone ................................................................................................... 3.7

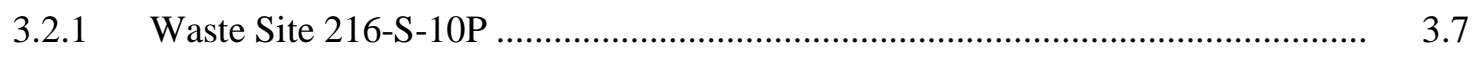

3.2.2 Waste Site 216-U-10 ...................................................................................... 3.7

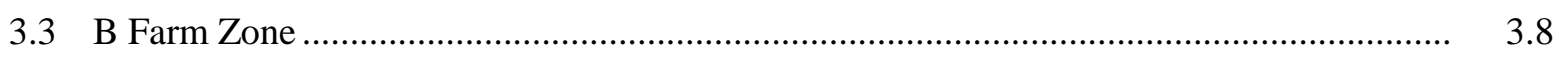

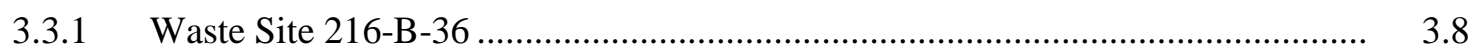

3.3.2 Waste Site 216-B-37 ................................................................................... 3.8

3.3.3 Waste Site 216-B-42 ….......................................................................... 3.8

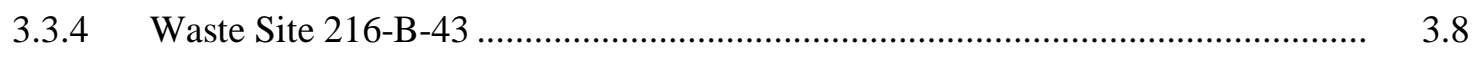

3.3.5 Waste Site 216-B-44 …............................................................................... 3.10

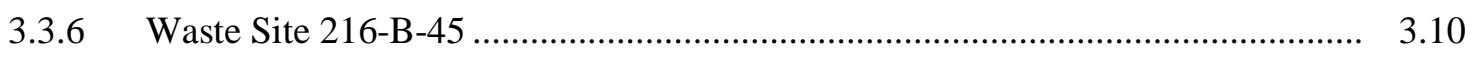

3.3.7 Waste Site 216-B-46 ................................................................................ 3.10

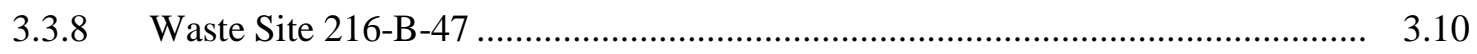

3.3.9 Waste Site 216-B-48 ............................................................................... 3.10

3.3.10 Waste Site 216-B-49 ............................................................................ 3.10

3.3.11 Waste Site 216-B-7A\&B........................................................................... 3.11

3.3.12 Waste Site 216-B-8 .................................................................................. 3.11

3.3.13 Waste Site 241-BX-101 .............................................................................. 3.11

3.3.14 Waste Site 241-BX-102 ................................................................................... 3.12

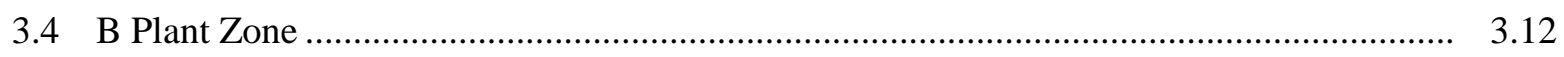

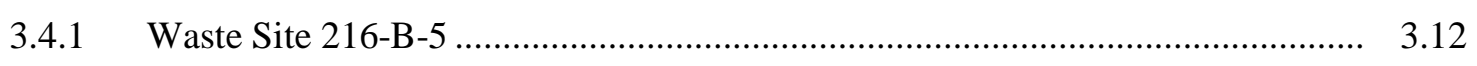

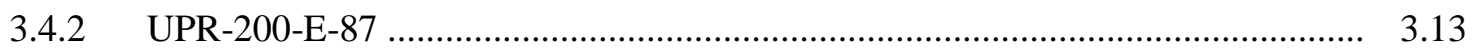




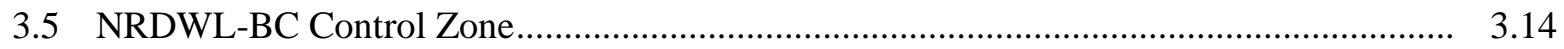

3.5.1 Waste Site 216-B-53A …............................................................................... 3.14

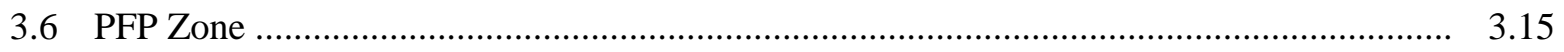

3.6.1 Waste Site 216-Z-1\&2 ....................................................................... 3.15

3.6.2 Waste Site 216-Z-10 .............................................................................. 3.16

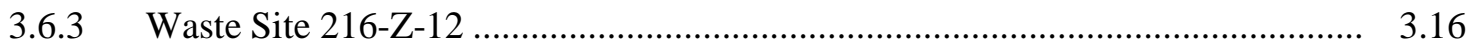

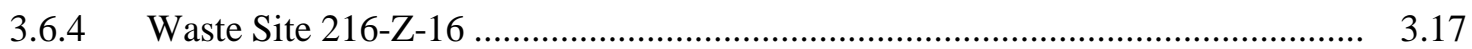

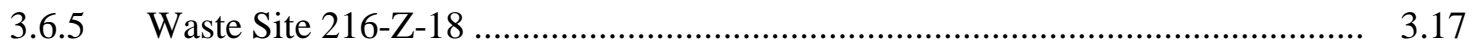

3.6.6 Waste Site 216-Z-1A.............................................................................. 3.17

3.6.7 Waste Site 216-Z-20 _................................................................................. 3.18

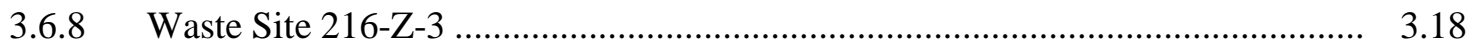

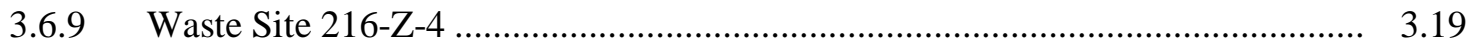

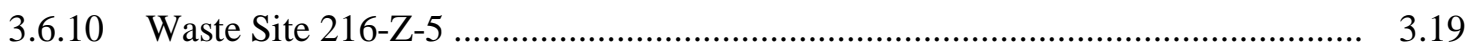

3.6.11 Waste Site 216-Z-6 ...................................................................................... 3.19

3.6.12 Waste Site 216-Z-7 ..................................................................................... 3.19

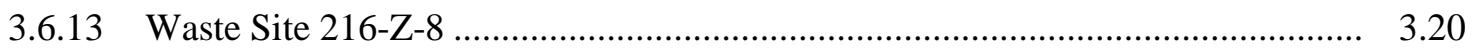

3.6.14 Waste Site 216-Z-9 ................................................................................. 3.20

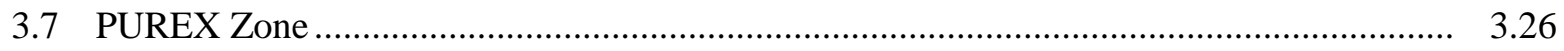

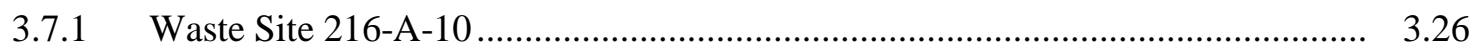

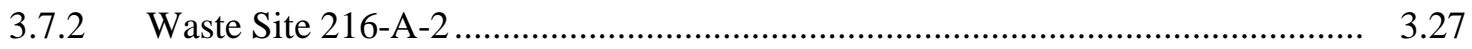

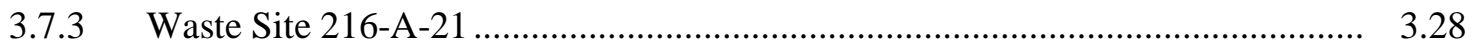

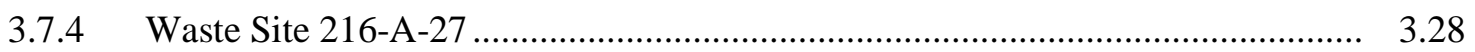

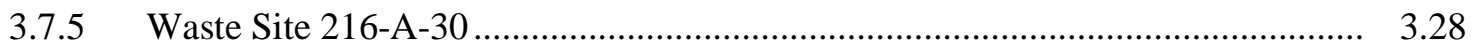

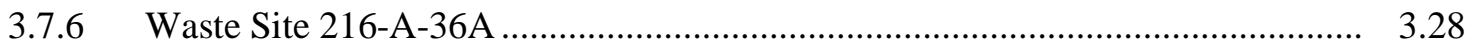

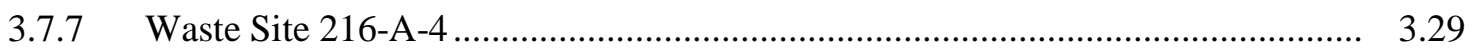

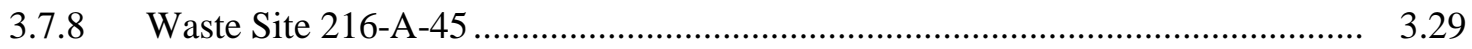

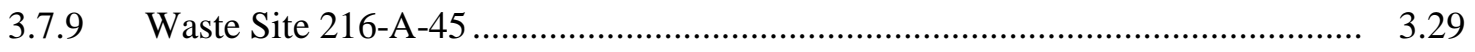

3.7.10 Waste Site 216-A-5 ................................................................................... 3.29

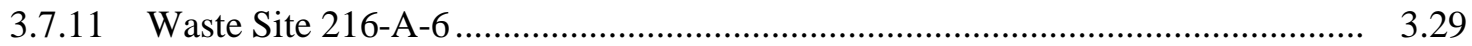

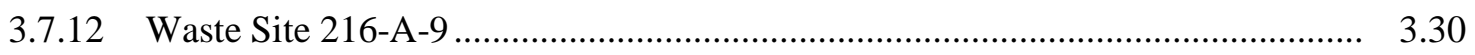

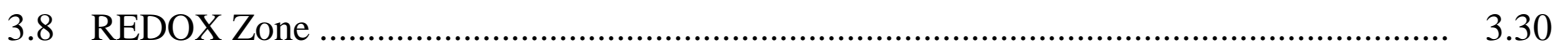

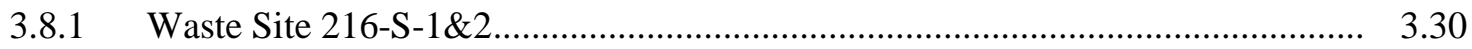

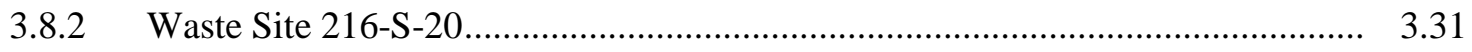

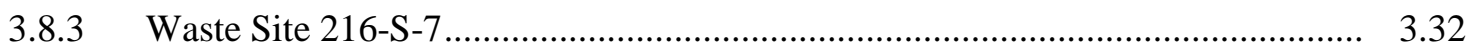

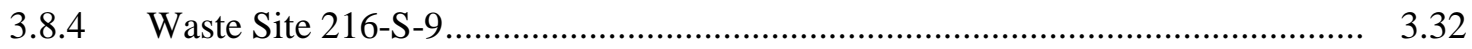

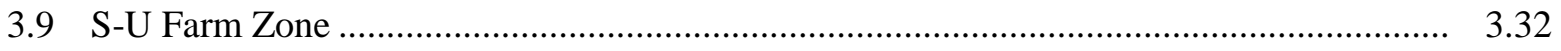

3.9.1 Waste Site 241-SX-115 .............................................................................. 3.32 


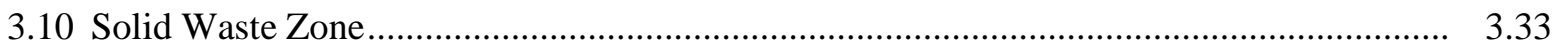

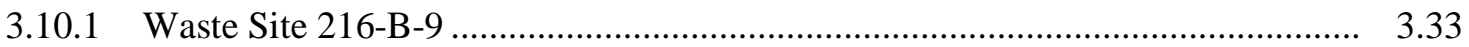

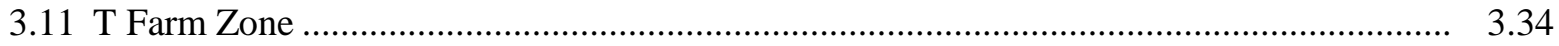

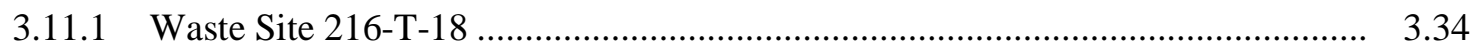

3.11.2 Waste Site 216-T-19 ............................................................................... 3.34

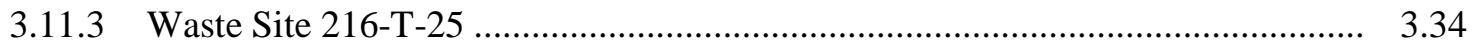

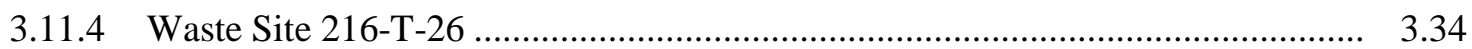

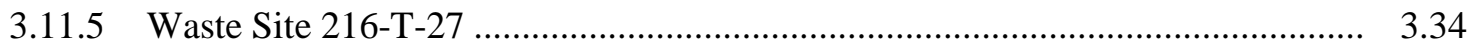

3.11.6 Waste Site 216-T-28 _................................................................................ 3.36

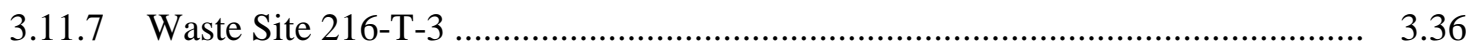

3.11.8 Waste Site 216-T-32 .......................................................................... 3.36

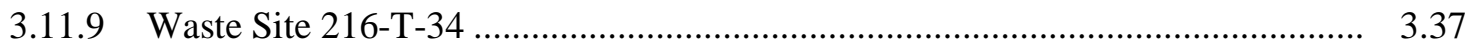

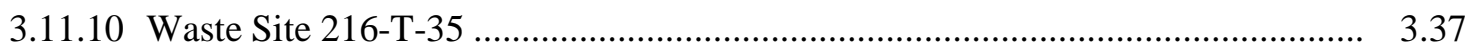

3.11.11 Waste Site 216-T-36 ................................................................................... 3.37

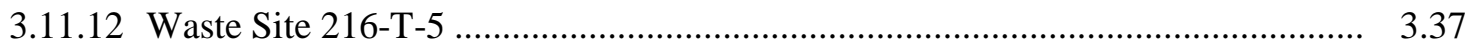

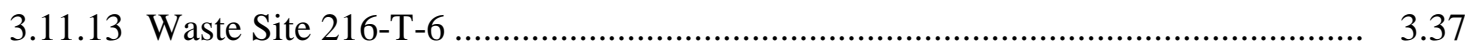

3.11.14 Waste Site 216-T-7 .............................................................................. 3.37

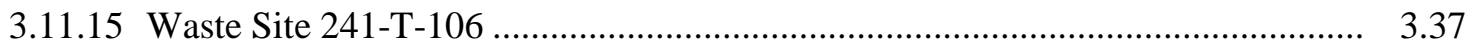

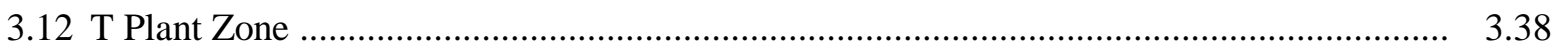

3.12.1 Waste Site 216-T-33 ............................................................................ 3.38

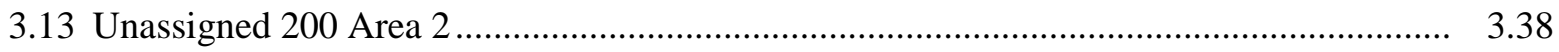

3.13.1 Waste Site UPR-200-W-102 ….................................................................... 3.38

3.13.2 Waste Site UPR-200-W-103 ........................................................................ 3.39

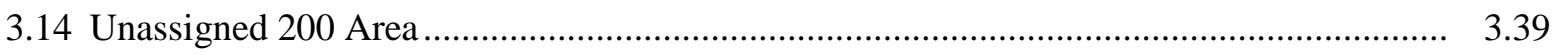

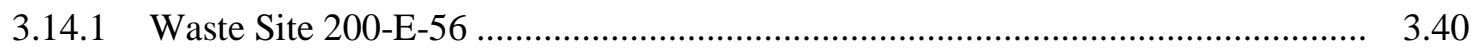

3.14.2 Waste Site 200-E-57 ............................................................................ 3.40

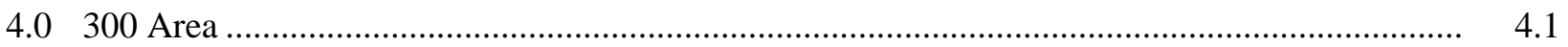

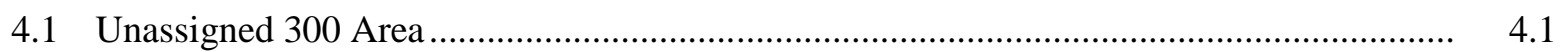

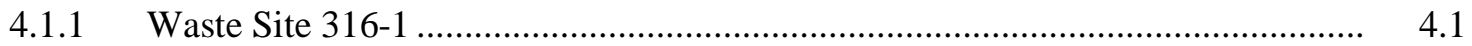

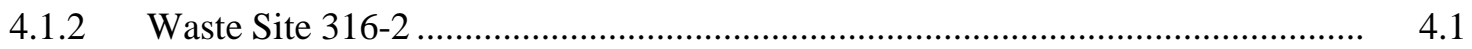

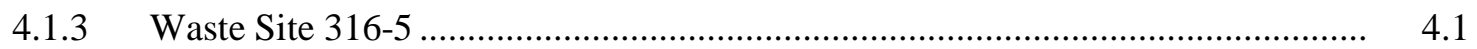

5.0 Summary and Conclusions ................................................................................................

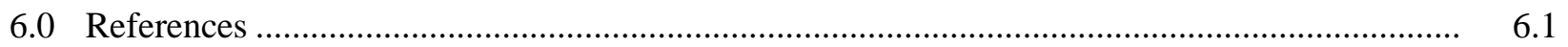




\section{Figures}

1.1 Hanford Site Geography and Major Operational Areas....................................................... 1.2

3.1 Closure Zones Associated with the 200 East and West Areas and Vicinity .............................. 3.2

3.2 Plutonium, Americium, and TBP Concentrations as a Function of Depth Measured in Soil Samples from Well 299-W15-46.

3.3 Plutonium, Americium, and $\mathrm{pH}$ as a Function of Depth Measured in Soil Samples from Well 299-W15-46

3.4 Nitrate Concentrations as a Function of Depth Measured in Soil Samples from Wells 299-W15-46 and 299-W15-48.

3.5 Plutonium, Americium, and TBP Concentrations as a Function of Depth Measured in Soil Samples from Well 299-W15-48.

\section{Tables}

2.1 Characterization Results for 100-N Area Liquid Waste Disposal Facilities............................ 2.1

3.1 Distribution of Plutonium-239 by Category and Percentage of Total Inventory ...................... 3.3

3.2 Distribution of Americium-241 by Category and Percentage of Total Inventory ..................... 3.4

3.3 Distribution of Neptunium-237 by Category and Percentage of Total Inventory..................... 3.5

3.4 200-E Ponds Zone Waste Sites and Associated Quantities of Plutonium, Americium, and Neptunium Nuclides Disposed, Decayed to January 1, 2001 .......................................... 3.6

3.5 200-W Ponds Zone Waste Sites and Associated Quantities of Plutonium, Americium, and Neptunium Nuclides Disposed, Decayed to January 1, 2001

3.6 B Farm Zone Waste Sites and Associated Quantities of Plutonium, Americium, and Neptunium Nuclides Disposed, Decayed to January 1, 2001

3.7 B Plant Zone Waste Sites and Associated Quantities of Plutonium, Americium, and Neptunium Nuclides Disposed, Decayed to January 1, 2001

3.8 NRDWL-BC Control Zone Waste Sites and Associated Quantities of Plutonium, Americium, and Neptunium Nuclides Disposed, Decayed to January 1, 2001

3.9 PFP Waste Sites and Associated Quantities of Plutonium, Americium, and Neptunium Nuclides Disposed, Decayed to January 1, 2001

3.10 Maximum Concentration and Depth Interval for Plutonium-239/240, Americium-241, Neptunium-237, TBP; and Lowest pH Value and Depth Interval, Well 299-W15-46

3.11 Maximum Concentration and Depth Interval for Plutonium-239/240, Americium-241, Neptunium-237, and TBP, Well 299-W15-48

3.12 PUREX Zone Waste Sites and Associated Quantities of Plutonium, Americium, and Neptunium Nuclides Disposed, Decayed to January 1, 2001

3.13 REDOX Zone Waste Sites and Associated Quantities of Plutonium, Americium, and Neptunium Nuclides Disposed, Decayed to January 1, 2001

3.14 S-U Farm Zone Waste Sites and Associated Quantities of Plutonium, Americium, and Neptunium Nuclides Disposed, Decayed to January 1, 2001 
3.15 Liquid Waste Sites within the Solid Waste Zone and Associated Quantities of Plutonium, Americium, and Neptunium Nuclides Disposed, Decayed to

January 1, 2001

3.16 T Farm Zone Waste Sites and Associated Quantities of Plutonium, Americium, and Neptunium Nuclides Disposed, Decayed to January 1, 2001

3.17 T Plant Zone Waste Sites and Associated Quantities of Plutonium, Americium, and Neptunium Nuclides Disposed, Decayed to January 1, 2001

3.18 Unassigned 200 Area 2 Waste Sites and Associated Quantities of Plutonium, Americium, and Neptunium Nuclides Disposed, Decayed to January 1, 2001

3.19 Unassigned 200 Area Waste Sites and Associated Quantities of Plutonium, Americium, and Neptunium Nuclides Disposed, Decayed to January 1, 2001

4.1 Unassigned 300 Area Waste Sites and Associated Quantities of Plutonium, Americium, and Neptunium Nuclides Disposed, Decayed to January 1, 2001 


\subsection{Introduction}

This review was undertaken by Pacific Northwest National Laboratory (PNNL) to evaluate and document the extent of transuranic (primarily plutonium and americium) contamination at the U.S. Department of Energy (DOE) Hanford Site, near Richland, Washington. The results of this review can be used to provide a basis for prioritizing waste sites contaminated with transuranic radionuclides for remedial investigation. The primary focus is on liquid waste disposal sites and unplanned releases (UPRs) in which liquid wastes containing plutonium and americium were released directly to the soil.

Figure 1.1 illustrates the Hanford Site geography and major operational areas. For consideration of final remedial actions, the site is divided into the Columbia River Corridor and the Central Plateau (Kincaid et al. 2004). The river corridor includes waste sites and facilities in each of the 100 Areas as well as the 300, and 400 Areas. The Central Plateau describes the region associated with operations and waste sites of the 200 Areas. DOE is developing a strategy for closure of the river corridor and Central Plateau. At the time of closure, waste management activities will shrink to a core zone within the Central Plateau. The core zone will contain the majority of Hanford's permanently disposed waste. Currently, DOE is proposing to shrink the portion of the Hanford Site that will require long-term active management to as little as 10 square miles within the Central Plateau Area (Cary 2009).

The following sections provide specific details regarding what is known regarding transuranic radionuclide contamination at specific waste sites at Hanford. The major sections are 100 Areas, 200 Areas, and 300 Areas. The 200 Areas section is organized according to closure zone. Only sites that contain $1 \mathrm{Ci}$ or more of plutonium-239/240 or americium-241 are discussed in detail. 


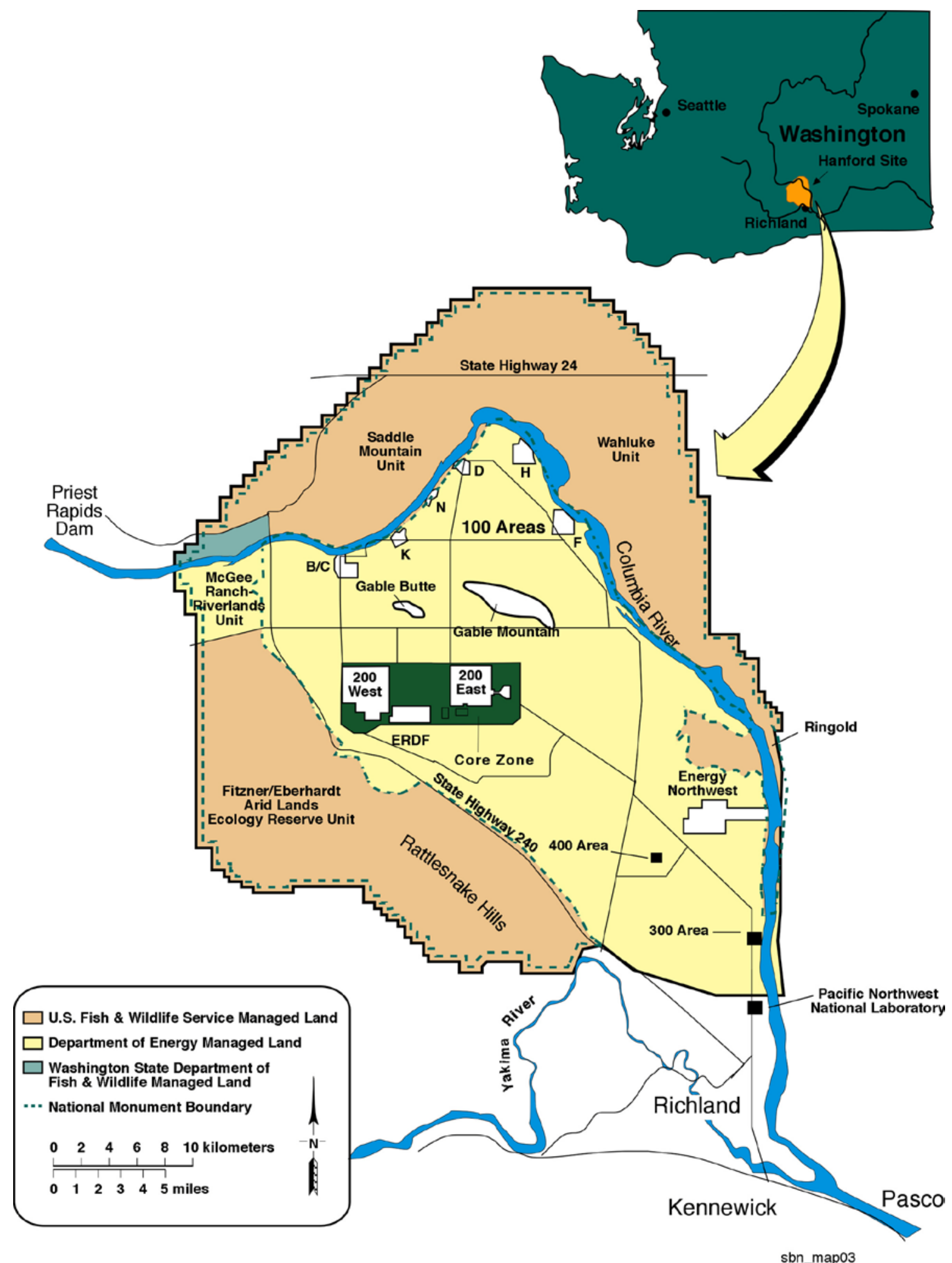

Figure 1.1. Hanford Site Geography and Major Operational Areas 


\subsection{Areas}

Cumulative radionuclide inventories of 100 Area cribs and trenches (decayed to December 31, 1998) are presented in Diediker (1999). Only three sites have plutonium-239/240 or americium-241 inventories above $1 \mathrm{Ci}$. These sites are 116-K-2 (100-K Trench) with $4.99 \mathrm{Ci}$ plutonium-239/240, 116-N-1 (1301-N Crib and Trench) with 23.0 Ci plutonium-239/240, and 116-N-3 (1325 Crib and Trench) with 2.8 Ci plutonium-239/240.

Some limited characterization work for the 116-K-2 (100-K Trench) is available. Between 1975 and 1976, United Nuclear Industries, Inc. conducted a radiological characterization program of waste sites in the 100 Areas that were retired at that time (Dorian and Richards 1978). Using results from the borehole samples collected along the 116-K-2 site (100-K Trench), an average concentration of plutonium for the potentially contaminated soil column was estimated to be $8.5 \mathrm{pCi} / \mathrm{g}$ plutonium-239/240. The highest concentration measured in any of the soil samples was $130 \mathrm{pCi} / \mathrm{g}$ plutonium-239/240. This sample was

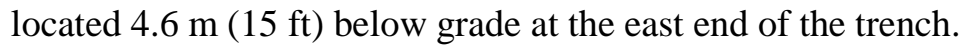

Characterization of 100-N Area liquid waste disposal facilities-116-N-1 (1301-N Crib and Trench) and 116-N-3 (1325-N Crib and Trench) — has been conducted as part of planned remedial actions (Ludowise 1999). Surface sediment samples were collected from the 116-N-1 Trench (1301-N Trench) and the 116-N-3 Crib (1325-N Crib). In addition, test pits were dug in the 116-N-1 Trench (1301-N Trench) to a depth of $1.51 \mathrm{~m}$ (5.0 ft), and the 116-N-3 Trench (1325-N Trench) to a depth of $1.37 \mathrm{~m}$ $(4.5 \mathrm{ft})$. The range of plutonium and americium concentrations determined in these samples is summarized in Table 2.1. The greatest concentration of plutonium and americium are found in the surface sediment samples. The highest plutonium and americium concentrations found in the surface sediment samples were very similar for both the 1301-N Trench and the 1325-N Crib, with concentrations of plutonium-239/240 reaching as high as 52,000 pCi/g, plutonium-238 reaching 10,500 pCi/g, and americium-241 attaining 44,700 pCi/g. The plutonium and americium concentrations found in the test pits were much lower than those found in the surface sediments. The highest values determined in the pit samples were approximately a factor of 100 lower than the high values determined in the surface samples for all three transuranic elements analyzed. In addition, the range in plutonium and americium concentrations found in the 1325-N Trench pit are considerably less than those determined in the 1301-N Trench pit. This is consistent with the much lower quantities of transuranic elements estimated to have been disposed in the 1325-N Crib and Trench relative to the 1301-N Crib and Trench, as indicated earlier in this section.

Table 2.1. Characterization Results for 100-N Area Liquid Waste Disposal Facilities

\begin{tabular}{lccc}
\hline \multicolumn{1}{c}{ Sample Type } & Pu-239/240 (pCi/g) & Pu-238 (pCi/g) & Am-241 (pCi/g) \\
\hline 1301-N Trench surface & $15,800-52,200$ & $2,980-10,500$ & $16,000-44,700$ \\
1325-N Crib surface & $5,850-52,100$ & $1,330-9,620$ & $4,150-41,100$ \\
1301-N Trench pit & $101-682 B^{(a)}$ & $13.6-97.8$ & $81.1-496$ \\
1325-N Trench pit & $26.9 B-408 B$ & $3.72 B-58.6$ & $13.4-226$ \\
\hline
\end{tabular}

(a) $\mathrm{B}$ indicates results are between required detection limit and blank contamination concentration. 


\section{$2.1 \quad 100-K$ Area Fuel Storage Basins}

Nuclear fuel storage basins_-K East (KE) and K West (KW) basins-associated with the 105-KE and 105-KW reactor buildings were used to store irradiated nuclear fuel elements from past operations (Johnson et al. 1995). Each basin held approximately 4.9 million L (1.3 million gal) of water. The water provided a radiation shield and thermal sink for heat generated by the stored fuel. The KW basin contained 964 metric tons of spent nuclear fuel (SNF) in sealed canisters; the KE basin contained 1,152 metric tons of SNF under water in open canisters (Ambalam and Watson 2004). The cladding on some of the nuclear fuel elements stored in the KE basin was damaged and stored in open canisters. This allowed contact between the irradiated fuel elements and basin water. It is estimated that $48 \mathrm{~m}^{3}$ $\left(1,700 \mathrm{ft}^{3}\right)$ of sludge containing radionuclides and sediments have accumulated in the KE basin (Ambalam and Watson 2004). Leakage of radiologically contaminated water from the KE basin occurred during the late 1970s that resulted in a tritium plume that migrated to the Columbia River. Due to the potential for release of hazardous substances from the $\mathrm{K}$ basins, cleanup of the $\mathrm{K}$ basins as a Comprehensive Environmental Response, Compensation, and Liability Act of 1980 (CERCLA) site is being conducted. As of 2006 (Chronister and Knollmeyer 2006), the spent fuel has been removed from the KE basin to stable, dry, safe storage. As of spring 2008 (Gerber 2008), the remaining sludge in the KE basin was removed, placed in containers, and transferred to the KW basin. Physical decontamination and decommissioning of the KE East basin began in October 2007. Complete removal of the basin superstructure is expected to be completed in 2009.

\subsubsection{KE Basin Leaks and Plutonium Contamination}

A significant leak occurred from the KE basin in early 1976 and continued until it was isolated near the end of 1979 (Johnson et al. 1995). The leak was attributed to a construction joint between the main basin and the fuel discharge chute. The leak rate was estimated to be 1,893 L/h (500 gal/h). Water balance calculations for KE basin conducted during February 1993 indicated another increase in KE basin water loss rate. This, along with the fact that elevated tritium concentrations continued to be found in monitoring wells immediately downgradient of the reactor building, indicated that continued leakage from the basin was occurring. Mitigating actions were taken to isolate the joint between the loading chute and the basin. These actions were completed in March 1995.

Beginning in January 1994, plutonium-239/240 concentrations in the storage basin water were measured monthly (R. M. Jochen, Materials and Energy Corporation, unpublished data). The range of values for 248 results for KE basin water samples collected from January 1994 through July 2005 was $410 \mathrm{pCi} / \mathrm{L}$ to $1.6 \times 10^{5} \mathrm{pCi} / \mathrm{L}$ with an average and standard deviation of $1.43 \times 10^{4} \pm 1.36 \times 10^{4} \mathrm{pCi} / \mathrm{L}$. Using the average concentration of plutonium in the KE basin water, and the average leak rate of 1,893 L/h from early 1976 to the end of 1979 and a leak rate of $38 \mathrm{~L} / \mathrm{h}$ from 1980 to 1995 (Johnson et al. 1995), it is estimated that approximately $0.9 \mathrm{Ci}$ of plutonium-239/240 leaked from the KE basin into the sediments beneath the basin between 1976 through 1979.

Groundwater monitoring in wells located downgradient from the basins indicate that no detectable plutonium is being transported through the aquifer in groundwater. 


\subsubsection{Chemistry of Plutonium in Groundwater at the 100-K Area}

A study of the chemistry of plutonium in groundwater has been conducted at the 100-K Area (Buesseler et al. 2003; Dai et al. 2005). The concentration, size distribution, reduction-oxidation (redox) state, and isotopic composition of plutonium in groundwater from the 100-K Area were examined. Results indicate that total plutonium concentrations were extremely low, ranging from $10^{-4}$ to $10^{-6} \mathrm{pCi} / \mathrm{kg}$. The DOE-derived concentration guide for plutonium is $30 \mathrm{pCi} / \mathrm{L}$. Size fractionation data from two wells suggested that $7 \%$ to $29 \%$ of the plutonium is associated with colloids (operationally defined as particles between $1 \mathrm{kDa}$ and $0.2 \mu \mathrm{m}$ in size. Plutonium in the colloidal fraction was exclusively in the more reduced $\mathrm{Pu}(\mathrm{III} / \mathrm{IV}$ ) form, consistent with the higher affinity of plutonium in the lower oxidation states for particle surfaces. Analysis of the isotopic composition of plutonium in the groundwater suggested the presence of at least two local sources of groundwater plutonium. These were local Hanford reactor operations at the 100-K Area and SNF from the N Reactor, which was stored in the K basins.

Comparison of results from one well (199-K-27) to a more downstream well (199-K-32A) indicated that the total plutonium concentration decreased by over an order of magnitude and that the colloidal fraction of plutonium decreased from $13 \%$ to $29 \%$ in Well $199-\mathrm{K}-27$ to $7 \%$ to $10 \%$ in Well $199-\mathrm{K}-32 \mathrm{~A}$. From these results, it was concluded that colloid facilitated transport of plutonium in groundwater is not a significant process under typical conditions at the Hanford Site.

\section{$2.2 \quad 100-\mathrm{N}$ Area}

In addition to the studies of plutonium in groundwater at the $100-\mathrm{K}$ Area, work was conducted at the 100-N Area (Buesseler et al. 2003). The highest concentration of plutonium-239 was found at Well 199$\mathrm{N}-47$, on the order of 106 atoms $/ \mathrm{kg}$, equivalent to $0.00005 \mathrm{pCi} / \mathrm{kg}$. Because the plutonium concentrations were so low, additional studies of size distribution, redox state, and isotopic composition were not conducted for the $100-\mathrm{N}$ samples as was done for the $100-\mathrm{K}$ samples.

In an earlier study of transuranic species in groundwater at the 100-N Area, low concentrations of plutonium and americium also were determined (Cowen et al. 1985). In this study, measurements of plutonium and americium were measured in influent water to the 1301-N Trench, groundwater from several wells immediately downstream of the trench, and in N Springs water. The highest plutonium and americium concentrations measured in this study were in influent water to the 1301-N Trench collected from manways. The highest plutonium concentrations measured were $100 \mathrm{pCi} / \mathrm{L}$ (dissolved plutonium) and $83 \mathrm{pCi} / \mathrm{L}$ (particulate plutonium). The highest americium concentrations measured were $14.2 \mathrm{pCi} / \mathrm{L}$ (dissolved) and $56 \mathrm{pCi} / \mathrm{L}$ (particulate). The highest concentrations of plutonium and americium measured

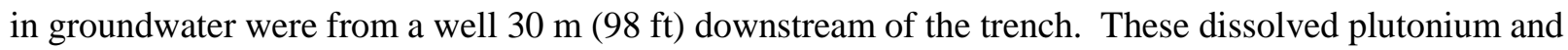
dissolved americium concentrations were $0.072 \mathrm{pCi} / \mathrm{L}$ and $0.023 \mathrm{pCi} / \mathrm{L}$, respectively. Particulate concentrations of plutonium and americium in these samples were less than $2 \%$ of the total. The highest dissolved concentrations of plutonium and americium measured in N Springs water were $0.0010 \mathrm{pCi} / \mathrm{L}$ and $0.001 \mathrm{pCi} / \mathrm{L}$, respectively. 


\subsection{Areas}

The Remediation and Closure Science Project ${ }^{1}$ develops data, methods, and tools to determine contaminant inventory; contaminant transport in the vadose zone, groundwater, and river; and to predict ecological impacts. Among the various tasks in this project was one to develop a Soil Inventory Model (SIM), a probabilistic approach to estimate the inventory of contaminants that were released to the soil during the Hanford Site production mission (Corbin et al. 2005). The scope of the SIM excludes solid wastes and is confined to liquid waste releases within the 200 Areas; a select number of sites are added from within the 300 Area. Results from the SIM were the primary data source used in this review to determine inventories of transuranic radionuclides disposed in 200 Area sites.

Reference information for the SIM waste stream labels used in this document are provided in Table 3-1 and Table A2-1 of Corbin et al. (2005). The principal source for total disposal volume, waste stream assignment, and site location information for the SIM is the Waste Information Data System (WIDS) database (DOE/RL 2002a). This information was corroborated (and modified or corrected in some cases) from several other references and source documents cited in Section A6.0 of Corbin et al. (2005), and in certain instances, engineering volume estimates and waste stream assignments are prepared for selected sites. Maxfield (1979) also provided information of a more limited nature for waste types and waste stream composition. Field and Jones (2005) was used as the source data to define and parameterize the tank leaks using the Hanford Defined Waste Model, Rev. 5 (Higley et al. 2004). Except as noted in Table 3-1 of Corbin et al. (2005), the Hanford Defined Waste (HDW) Model (Agnew et al. 1997; Higley et al. 2004) waste stream values are used (and modified when appropriate) for input composition and uncertainty information. The comprehensive set of waste streams developed or used in the evolution of the SIM is presented in Table A2-1 of Corbin et al. (2005), together with the reference source. The comprehensive derivation information and quantitative description is provided in Appendix D of Corbin et al. (2005). Results of the SIM and associated source documents used as input to the model were considered in this review to determine which 200 Area waste sites have received significant quantities of plutonium and americium. Additional information regarding individual sites was collected from other Hanford reports and journal articles. A search of the Hanford Environmental Information System (HEIS) database also was used to identify locations and concentrations of plutonium and americium contamination in groundwater and some sediments.

In the SIM, individual sites were grouped into 20 different categories (alternately called operable units or closure zones). These categories were determined by historical site use, geographic location, and facility association; although in some cases, there were no strong associations other than geographic. Figure 3.1, a map of the 200 West and 200 East Areas and vicinity, shows the locations of the closure zones within these areas that have had more than $1 \mathrm{Ci}$ of plutonium-239 disposed to them.

All quantities of radionuclides presented in this section were decay-corrected to January 1, 2001 (Corbin et al. 2005). However, it does not appear that production of daughter products was taken into account.

\footnotetext{
${ }^{1}$ The Remediation and Closure Science Project, funded at the time by Fluor Hanford, Inc., currently is funded by CH2M HILL Plateau Remediation Company for the DOE Richland Operations Office.
} 


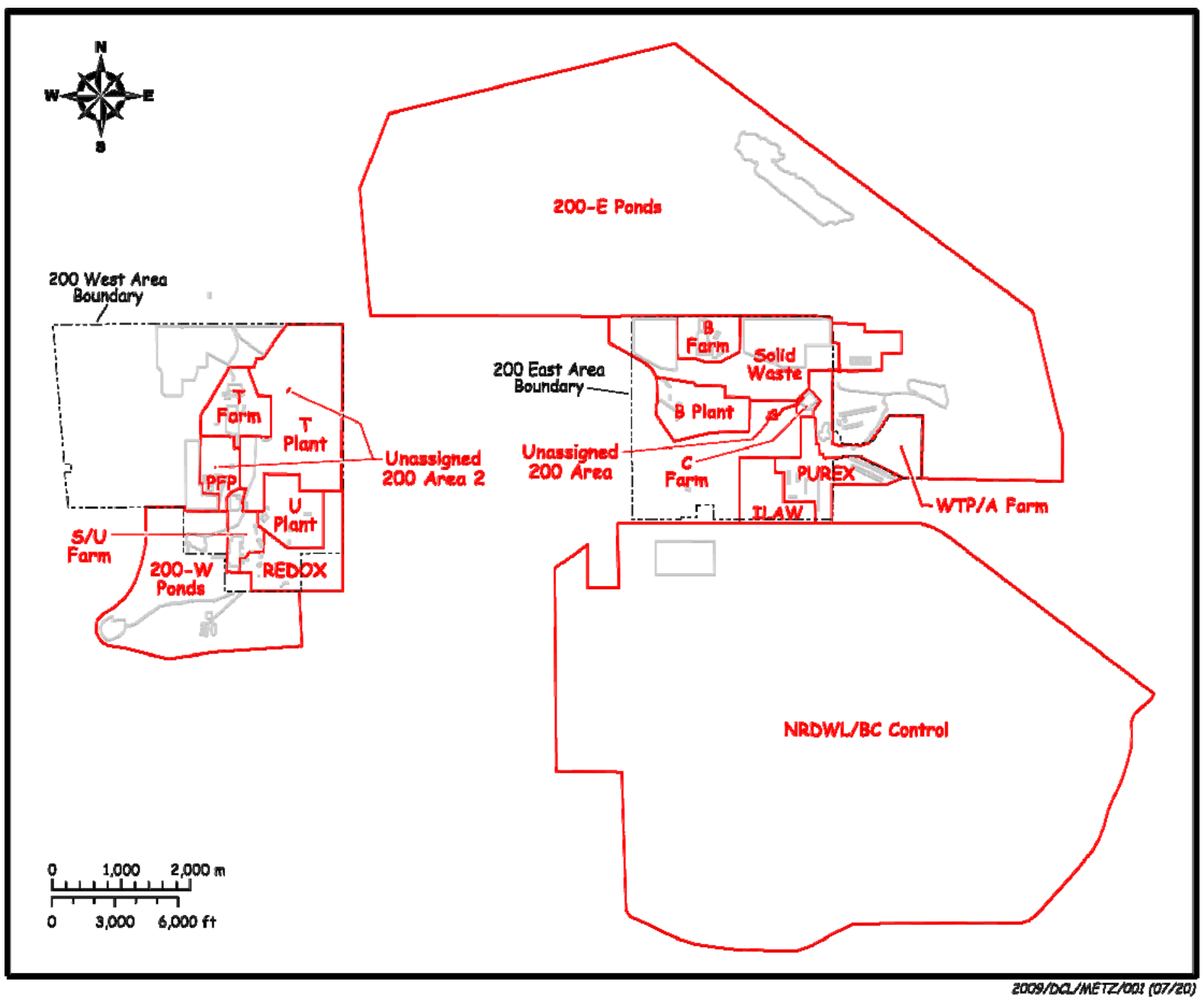

Figure 3.1. Closure Zones Associated with the 200 East and West Areas and Vicinity 
The quantities of plutonium-239 that were released to each of the 20 closure zones shown in Figure 3.1 are summarized in Table 3.1 (Corbin et al. 2005). A total 11,800 Ci were released to all the waste sites within the 200 Area closure zones. The largest quantities of plutonium-239 were released to waste sites in the Plutonium Finishing Plant (PFP) zone, with a total of 10,200 Ci (86.2\%). Other closure zones with notably high releases of plutonium are the T Farm zone with $408 \mathrm{Ci}$ (3.5\%), the Plutonium Uranium Extraction (PUREX) zone with $330 \mathrm{Ci}$ (2.8\%), 200-W Ponds zone with $324 \mathrm{Ci}$ (2.8\%), B Farm zone with $183 \mathrm{Ci}$ (1.6\%), and the REDOX zone with $164 \mathrm{Ci}(1.4 \%)$.

Table 3.1. Distribution of Plutonium-239 by Category and Percentage of Total Inventory, 200 Area Closure Zones

\begin{tabular}{lcc}
\hline \multicolumn{1}{c}{ Closure Zone } & Quantity of Pu-239 (Ci) & \% of Total Inventory \\
\hline 200-E Ponds Zone & 50 & 0.42 \\
200-W Ponds Zone & 324 & 2.75 \\
B Farm Zone & 183 & 1.56 \\
B Plant Zone & 40.3 & 0.34 \\
NRDWL-BC Control Zone & 100 & 0.85 \\
PFP Zone & 10,200 & 86.2 \\
PUREX Zone & 330 & 2.80 \\
REDOX Zone & 164 & 1.39 \\
S-U Farm Zone & 4.06 & 0.03 \\
Semiworks Zone & 0.471 & 0.00 \\
Solid Waste Zone & 8.10 & 0.07 \\
T Farm Zone & 408 & 3.46 \\
T Plant Zone & 2.06 & 0.02 \\
U Plant Zone & 0.143 & 0.00 \\
Unassigned 200 Area 1 & 0.000186 & 0.00 \\
Unassigned 200 Area 2 & 5.46 & 0.05 \\
Unassigned 200 Area & 1.13 & 0.01 \\
Unassigned 300 Area & 9.96 & 0.08 \\
WM Zone & 0.0487 & 0.00 \\
WTP-ETF-A-C Farm Zone & 0.761 & 0.01 \\
\hline Total & $\mathbf{1 1 , 8 0 0}$ & \\
\hline
\end{tabular}

Table 3.2 summarizes the quantities of americium-241 that were released to these 20 closure zones (Corbin et al. 2005). A total of 28,730 Ci were released to all the wastes sites within the 200 Area closure zones. By far, the largest quantities of americium-241 released were to waste sites in the PFP zone, with a total of $27,900 \mathrm{Ci}(97.1 \%)$. All other closure zones had releases that were less than $1.0 \%$ of the total. 
Table 3.2. Distribution of Americium-241 by Category and Percentage of Total Inventory, 200 Area Closure Zones

\begin{tabular}{lcc}
\hline \multicolumn{1}{c}{ Closure Zone } & Quantity of Am-241 (Ci) & \% of Total Inventory \\
\hline 200-E Ponds Zone & 15.7 & 0.05 \\
200-W Ponds Zone & 212 & 0.74 \\
B Farm Zone & 74.4 & 0.26 \\
B Plant Zone & 0.424 & 0.00 \\
NRDWL-BC Control Zone & 186 & 0.65 \\
PFP Zone & 27,900 & 97.1 \\
PUREX Zone & 130 & 0.45 \\
REDOX Zone & 98.5 & 0.34 \\
S-U Farm Zone & 4.92 & 0.02 \\
Semiworks Zone & 0.256 & 0.00 \\
Solid Waste Zone & 0.220 & 0.00 \\
T Farm Zone & 47.0 & 0.16 \\
T Plant Zone & 0.113 & 0.00 \\
U Plant Zone & 0.341 & 0.00 \\
Unassigned 200 Area 1 & $1.47 \mathrm{E}-06$ & 0.00 \\
Unassigned 200 Area 2 & 1.31 & 0.00 \\
Unassigned 200 Area & 53.6 & 0.19 \\
Unassigned 300 Area & 0.220 & 0.00 \\
WM Zone & 0.00083 & 0.00 \\
WTP-ETF-A-C Farm Zone & 5.10 & 0.02 \\
\hline Total & $\mathbf{2 8 , 7 3 0}$ & \\
\hline
\end{tabular}

Table 3.3 summarizes the quantities of neptunium-237 that were released to these 20 closure zones (Corbin et al. 2005). A total of $53.7 \mathrm{Ci}$ were released to all the wastes sites within the 200 Area closure zones. The largest quantities of neptunium-237 were released to waste sites in the PFP zone, with a total of $41.8 \mathrm{Ci}$ (77.9\%). Other closure zones with notably high releases of neptunium are the PUREX zone with $4.04 \mathrm{Ci}(7.5 \%)$, the nonradioactive dangerous waste landfill (NRDWL)-BC Control zone with $3.29 \mathrm{Ci}$ (6.1\%), 200-W Ponds zone with 1.26 Ci (2.4\%), B Farm zone with $1.21 \mathrm{Ci}$ (2.3\%), and the REDOX zone with $1.15 \mathrm{Ci}(2.1 \%)$.

Details of what is known regarding individual waste sites within these closure zones are discussed in the following sections. Only sites that received $1 \mathrm{Ci}$ (16 g) of plutonium-239 or $1 \mathrm{Ci}$ (0.3 g) americium-241 are discussed in this review. The level of detail presented here is generally greater for sites with higher quantities of disposed plutonium and americium but may be limited by the availability of detailed characterization information. 
Table 3.3. Distribution of Neptunium-237 by Category and Percentage of Total Inventory, 200 Area Closure Zones

\begin{tabular}{lcc}
\hline \multicolumn{1}{c}{ Closure Zone } & Quantity of Np-237 (Ci) & \% of Total Inventory \\
\hline 200-E Ponds Zone & 0.213 & 0.40 \\
200-W Ponds Zone & 1.26 & 2.35 \\
B Farm Zone & 1.21 & 2.25 \\
B Plant Zone & 0.018 & 0.03 \\
NRDWL-BC Control Zone & 3.29 & 6.13 \\
PFP Zone & 41.8 & 77.9 \\
PUREX Zone & 4.04 & 7.53 \\
REDOX Zone & 1.15 & 2.14 \\
S-U Farm Zone & 0.143 & 0.27 \\
Semiworks Zone & 0.000178 & 0.00 \\
Solid Waste Zone & 0.00284 & 0.01 \\
T Farm Zone & 0.423 & 0.79 \\
T Plant Zone & 0.0027 & 0.01 \\
U Plant Zone & 0.000822 & 0.00 \\
Unassigned 200 Area 1 & $8.27 \mathrm{E}-07$ & 0.00 \\
Unassigned 200 Area 2 & 0.0208 & 0.04 \\
Unassigned 200 Area & 0.00437 & 0.01 \\
Unassigned 300 Area & 0.0412 & 0.08 \\
WM Zone & 0.000163 & 0.00 \\
WTP-ETF-A-C Farm Zone & 0.0389 & 0.07 \\
\hline Total & 53.66 & \\
\hline
\end{tabular}

\subsection{0-E Ponds Zone}

Waste sites in the 200-E Ponds zone and associated quantities of plutonium, americium, and neptunium nuclides disposed in curies (decayed to January 1, 2001) are listed in Table 3.4. Only two sites in this closure zone received plutonium-239 or americium-241 above $1.0 \mathrm{Ci}$. These sites are the Gable Mountain Pond (Waste Site 216-A-25) and Waste Site 216-B-3.

\subsubsection{Waste Site 216-A-25}

Waste Site 216-A-25 (Gable Mountain Pond) operated from 1958 through 1985. The site received almost 294,000 ML of non-contact or lightly contaminated process waste over its operating lifetime (e.g., PUREX and B Plant process cooling water; Powerhouse water) with an excursion of high-level waste (Corbin et al. 2005). The estimated inventories of plutonium-239/240 and americium-241 are $300 \mathrm{Ci}$ and $2.84 \mathrm{Ci}$, respectively (Table 3.4). References used to determine the contributing volumes are located in Appendix A of Corbin et al. (2005). After the excursion of high-level waste (UPR-200-E-34), bentonite clay was spread over the bottom of the pond to control contamination by immobilizing the radionuclides 
Table 3.4. 200-E Ponds Zone Waste Sites and Associated Quantities of Plutonium, Americium, and Neptunium Nuclides Disposed (Ci), Decayed to January 1, 2001

\begin{tabular}{lcccccc}
\hline \multicolumn{1}{c}{ Waste Site } & Pu-238 & Pu-239 & Pu-240 & Pu-241 & Am-241 & Np-237 \\
\hline 216-A-1 & $<0.00$ & $<0.00$ & $<0.00$ & $<0.00$ & $<0.00$ & $<0.00$ \\
216-A-18 & $<0.00$ & $<0.00$ & $<0.00$ & $<0.00$ & $<0.00$ & $<0.00$ \\
$216-A-19$ & $<0.00$ & $<0.00$ & $<0.00$ & $<0.00$ & $<0.00$ & $<0.00$ \\
$216-A-20$ & $<0.00$ & $<0.00$ & $<0.00$ & $<0.00$ & $<0.00$ & $<0.00$ \\
$216-A-24$ & 0.02 & 0.35 & 0.09 & 0.82 & 0.30 & $<0.00$ \\
$216-A-25$ & 2.49 & 29.1 & 8.53 & 155 & 2.84 & 0.12 \\
$216-A-7$ & 0.03 & 0.61 & 0.15 & 1.33 & 0.18 & $<0.00$ \\
$216-A-8$ & 0.07 & 0.87 & 0.26 & 3.91 & 0.52 & $<0.00$ \\
$216-B-3$ & 1.82 & 19.1 & 5.2 & 140 & 11.9 & 0.09 \\
$216-N-1$ & $<0.00$ & $<0.00$ & $<0.00$ & $<0.00$ & $<0.00$ & $<0.00$ \\
$216-N-2$ & $<0.00$ & $<0.00$ & $<0.00$ & $<0.00$ & $<0.00$ & $<0.00$ \\
$216-N-3$ & $<0.00$ & $<0.00$ & $<0.00$ & $<0.00$ & $<0.00$ & $<0.00$ \\
$216-N-4$ & $<0.00$ & $<0.00$ & $<0.00$ & $<0.00$ & $<0.00$ & $<0.00$ \\
$216-N-5$ & $<0.00$ & $<0.00$ & $<0.00$ & $<0.00$ & $<0.00$ & $<0.00$ \\
$216-N-6$ & $<0.00$ & $<0.00$ & $<0.00$ & $<0.00$ & $<0.00$ & $<0.00$ \\
$216-N-7$ & $<0.00$ & $<0.00$ & $<0.00$ & $<0.00$ & $<0.00$ & $<0.00$ \\
\hline
\end{tabular}

in the upper sediment layers (Adam and Cearlock 1999). After it was decommissioned, the pond was backfilled with coarse- and fine-grained sediments to a level of 1 to $2.7 \mathrm{~m} \mathrm{(3} \mathrm{to} 9 \mathrm{ft}$ ) above the shoreline.

Limited characterization has been conducted at the site. Cushing and Watson (1974) analyzed radionuclides in sediment samples collected from the bottom of the pond with sediment coring tubes and Ekman dredges. The maximum concentrations measured for plutonium and americium were $1.5 \mathrm{pCi} / \mathrm{g}$ plutonium-239/240, less than $0.08 \mathrm{pCi} / \mathrm{g}$ plutonium-238, and $1.4 \mathrm{pCi} / \mathrm{g}$ americium-241. Concentrations were found to decrease with depth to $10 \mathrm{~cm}$ (3.9 in.).

\subsubsection{Waste Site 216-B-3}

This site operated from 1945 through 1996. The site received over 282,000 ML of bismuth phosphate process plant and B Plant cooling water; PUREX cooling water, chemical sewer, and stack drainage; and intermittent excursions of high-level waste (Corbin et al. 2005). The estimated inventories of plutonium-239/240 and americium-241 are 24.3 Ci and 11.9 Ci, respectively (Table 3.4). References used to determine the contributing volumes are located in Appendix A of Corbin et al. (2005). 


\subsection{0-W Ponds Zone}

Waste sites in the 200-W Ponds zone and associated quantities of plutonium, americium, and neptunium nuclides disposed (curies decayed to January 1, 2001) are listed in Table 3.5. Two sites in this closure zone (216-S-10 ${ }^{1}$ and 216-U-10) received plutonium-239 or americium-241 above $1.0 \mathrm{Ci}$.

Table 3.5. 200-W Ponds Zone Waste Sites and Associated Quantities of Plutonium, Americium, and Neptunium Nuclides Disposed (Ci), Decayed to January 1, 2001

\begin{tabular}{lcccccc}
\hline \multicolumn{1}{c}{ Waste Site } & Pu-238 & Pu-239 & Pu-240 & Pu-241 & Am-241 & Np-237 \\
\hline $216-S-10$ P $^{*}$ & 1.63 & 14.9 & 4.8 & 109 & 53.1 & 0.05 \\
$216-S-14$ & $<0.00$ & $<0.00$ & $<0.00$ & $<0.00$ & $<0.00$ & $<0.00$ \\
$216-S-16 P$ & $<0.00$ & 0.01 & $<0.00$ & $<0.00$ & $<0.00$ & $<0.00$ \\
$216-S-17$ & $<0.00$ & 0.01 & $<0.00$ & $<0.00$ & 0.01 & $<0.00$ \\
$216-S-19$ & $<0.00$ & $<0.00$ & $<0.00$ & $<0.00$ & $<0.00$ & $<0.00$ \\
$216-S-21$ & $<0.00$ & 0.06 & 0.01 & 0.09 & 0.02 & $<0.00$ \\
$216-S-25$ & 0.01 & 0.14 & 0.03 & 0.25 & $<0.00$ & $<0.00$ \\
$216-S-26$ & $<0.00$ & $<0.00$ & $<0.00$ & $<0.00$ & $<0.00$ & $<0.00$ \\
$216-S-4$ & $<0.00$ & $<0.00$ & $<0.00$ & $<0.00$ & $<0.00$ & $<0.00$ \\
$216-S-5$ & $<0.00$ & 0.01 & $<0.00$ & 0.01 & 0.01 & $<0.00$ \\
$216-S-6$ & 0.01 & 0.25 & 0.05 & 0.26 & 0.05 & $<0.00$ \\
$216-U-10$ & 26.0 & 308 & 91.9 & 1378 & 160 & 1.21 \\
$216-U-14$ & 0.01 & 0.22 & 0.05 & 0.40 & $<0.00$ & $<0.00$ \\
\hline
\end{tabular}

(a) Reports 216-S-10P, 216-S-10D, and 216-S-11 as one unit.

\subsubsection{Waste Site 216-S-10P}

This site operated from 1944 through 1952. The site received approximately 6,730 ML of REDOX chemical sewer, process cooling water, and miscellaneous drainage over its operating lifetime (Corbin et al. 2005). The estimated inventories of plutonium-239/240 and americium-241 are $19.7 \mathrm{Ci}$ and $53.1 \mathrm{Ci}$, respectively (Table 3.5). References used to determine the contributing volumes are located in Appendix A of Corbin et al. (2005).

\subsubsection{Waste Site 216-U-10}

This site received approximately 160,000 ML of PUREX, REDOX, and Z Plant process condensates; cooling water; laundry waste; powerhouse water; and chemical sewer waste (Corbin et al. 2005). The estimated inventories of plutonium-239/240 and americium-241 are $400 \mathrm{Ci}$ and $160 \mathrm{Ci}$, respectively (Table 3.5). The site operated during the period 1944-1995. The 216-U-10 (U Pond) and its associated 216-Z-19 Ditch have fission products and uranium distributed throughout most of the disposal system

\footnotetext{
${ }^{1}$ Reports 216-S-10P, 216-S-10D, and 216-S-11 as one unit.
} 
while transuranics (plutonium and americium) are localized more closely to the points of discharge (Last et al. 1994). The 216-Z-19 Ditch and its backfilled predecessors, the 216-Z-11 and 216-Z-1 ditches, received discharges containing plutonium-239/240, plutonium-238, and americium-241. More than 90\% of the plutonium inventory discharged to the U Pond disposal system was retained in these ditches. Plutonium-239 and americium-241 concentrations as high as 33,000 pCi/g and 8,200,000 pCi/g, respectively, were measured in sediment samples collected from the 216-Z-19 Ditch (in March and April 1976) (Last et al. 1994). Concentrations measured in surface samples collected from the U Pond delta in November 1978 were as high as 119,000 pCi/g (plutonium-239) and 8,300 pCi/g (americium-241) (Last et al. 1994). The highest concentrations of plutonium-239/240 and americium-241 measured in U Pond bottom sediments (in 1974) were $370 \mathrm{pCi} / \mathrm{g}$ and $320 \mathrm{pCi} / \mathrm{g}$, respectively (Last et al. 1994).

\subsection{B Farm Zone}

Waste sites in the B Farm zone and associated quantities of plutonium, americium, and neptunium nuclides disposed (curies decayed to January 1, 2001) are listed in Table 3.6. Thirteen sites in this closure zone received plutonium-239 or americium-241 above $1.0 \mathrm{Ci}$.

\subsubsection{Waste Site 216-B-36}

This site operated during 1954 , receiving $1.94 \mathrm{ML}$ of $1 \mathrm{C}$ waste $\left(\mathrm{BiPO}_{4}\right.$ first-cycle decontamination wastes and coating wastes) (Corbin et al. 2005). The estimated inventories of plutonium-239/240 and americium-241 are $0.9 \mathrm{Ci}$ and $1.01 \mathrm{Ci}$, respectively (Table 3.6). References used to determine the contributing volumes are located in Appendix A of Corbin et al. (2005).

\subsubsection{Waste Site 216-B-37}

This site operated during 1954, receiving 4.32 ML of 1C waste (Corbin et al. 2005). The estimated inventories of plutonium-239/240 and americium-241 are 2.00 Ci and 2.24 Ci, respectively (Table 3.6). References used to determine the contributing volumes are located in Appendix A of Corbin et al. (2005).

\subsubsection{Waste Site 216-B-42}

This site operated during 1954, receiving 1.5 ML of ferrocyanide waste as part of the scavenging campaign (Corbin et al. 2005). The estimated inventories of plutonium-239/240 and americium-241 are 1.32 $\mathrm{Ci}$ and $2.50 \mathrm{Ci}$, respectively (Table 3.6). References used to determine the contributing volumes are located in Appendix A of Corbin et al. (2005).

\subsubsection{Waste Site 216-B-43}

This site operated during 1954, receiving 2.12 ML of ferrocyanide waste as part of the scavenging campaign (Corbin et al. 2005). The estimated inventories of plutonium-239/240 and americium-241 are $1.87 \mathrm{Ci}$ and $3.53 \mathrm{Ci}$, respectively (Table 3.6). References used to determine the contributing volumes are located in Appendix A of Corbin et al. (2005). 
Table 3.6. B Farm Zone Waste Sites and Associated Quantities of Plutonium, Americium, and Neptunium Nuclides Disposed (Ci), Decayed to January 1, 2001

\begin{tabular}{|c|c|c|c|c|c|c|}
\hline Waste Site & $\mathrm{Pu}-238$ & Pu-239 & $\mathrm{Pu}-240$ & $\mathrm{Pu}-241$ & Am-241 & $\mathrm{Np}-237$ \\
\hline 216-B-11A\&B & $<0.00$ & 0.01 & $<0.00$ & $<0.00$ & $<0.00$ & $<0.00$ \\
\hline 216-B-35 & $<0.00$ & 0.43 & 0.06 & 0.14 & 0.55 & $<0.00$ \\
\hline 216-B-36 & 0.01 & 0.79 & 0.11 & 0.26 & 1.01 & 0.01 \\
\hline 216-B-37 & 0.02 & 1.75 & 0.25 & 0.57 & 2.24 & 0.02 \\
\hline 216-B-38 & 0.01 & 0.58 & 0.08 & 0.19 & 0.74 & 0.01 \\
\hline 216-B-39 & 0.01 & 0.62 & 0.09 & 0.20 & 0.80 & 0.01 \\
\hline 216-B-40 & 0.01 & 0.66 & 0.09 & 0.22 & 0.85 & 0.01 \\
\hline 216-B-41 & 0.01 & 0.58 & 0.08 & 0.19 & 0.75 & 0.01 \\
\hline 216-B-42 & 0.01 & 1.19 & 0.13 & 0.25 & 2.50 & 0.05 \\
\hline 216-B-43 & 0.01 & 1.69 & 0.18 & 0.35 & 3.53 & 0.06 \\
\hline 216-B-44 & 0.03 & 4.46 & 0.48 & 0.94 & 9.33 & 0.17 \\
\hline 216-B-45 & 0.03 & 4.00 & 0.43 & 0.84 & 8.19 & 0.15 \\
\hline 216-B-46 & 0.04 & 5.33 & 0.57 & 1.12 & 11.2 & 0.20 \\
\hline 216-B-47 & 0.02 & 2.93 & 0.32 & 0.62 & 6.13 & 0.11 \\
\hline 216-B-48 & 0.02 & 3.25 & 0.35 & 0.68 & 6.81 & 0.12 \\
\hline 216-B-49 & 0.04 & 5.33 & 0.57 & 1.12 & 11.2 & 0.20 \\
\hline 216-B-50 & $<0.00$ & 0.02 & $<0.00$ & 0.03 & $<0.00$ & $<0.00$ \\
\hline 216-B-51 & $<0.00$ & $<0.00$ & $<0.00$ & $<0.00$ & $<0.00$ & $<0.00$ \\
\hline 216-B-57 & $<0.00$ & 0.03 & 0.01 & 0.05 & 0.01 & $<0.00$ \\
\hline 216-B-7A\&B & 2.15 & 21.7 & 6.84 & 125 & 5.62 & 0.02 \\
\hline 216-B-8 & 0.55 & 126 & 9.74 & 12.7 & 1.12 & 0.03 \\
\hline 216-BY-201 & $<0.00$ & 0.03 & $<0.00$ & 0.01 & 0.07 & $<0.00$ \\
\hline 241-B-204 & $<0.00$ & $<0.00$ & $<0.00$ & $<0.00$ & $<0.00$ & $<0.00$ \\
\hline 241-BX-101 & $<0.00$ & 0.09 & 0.02 & 0.24 & 1.05 & $<0.00$ \\
\hline 241-B-107 & 0.01 & 0.24 & 0.05 & 0.34 & 0.26 & $<0.00$ \\
\hline 241-B-110 & $<0.00$ & 0.02 & $<0.00$ & 0.05 & 0.02 & $<0.00$ \\
\hline 241-B-201 & $<0.00$ & $<0.00$ & $<0.00$ & $<0.00$ & $<0.00$ & $<0.00$ \\
\hline 241-B-203 & $<0.00$ & $<0.00$ & $<0.00$ & $<0.00$ & $<0.00$ & $<0.00$ \\
\hline 241-BX-102 & $<0.00$ & 1.33 & 0.09 & 0.09 & 0.28 & 0.01 \\
\hline 241-BY-103 & $<0.00$ & $<0.00$ & $<0.00$ & 0.02 & 0.01 & $<0.00$ \\
\hline 241-BY-108 & $<0.00$ & 0.01 & $<0.00$ & 0.02 & 0.01 & $<0.00$ \\
\hline UPR-200-E-6 & $<0.00$ & $<0.00$ & $<0.00$ & $<0.00$ & $<0.00$ & $<0.00$ \\
\hline UPR-200-E-73 & $<0.00$ & $<0.00$ & $<0.00$ & $<0.00$ & $<0.00$ & $<0.00$ \\
\hline UPR-200-E-74 & $<0.00$ & $<0.00$ & $<0.00$ & $<0.00$ & $<0.00$ & $<0.00$ \\
\hline UPR-200-E-75 & $<0.00$ & $<0.00$ & $<0.00$ & $<0.00$ & $<0.00$ & $<0.00$ \\
\hline UPR-200-E-79 & $<0.00$ & 0.02 & $<0.00$ & $<0.00$ & 0.01 & $<0.00$ \\
\hline UPR-200-E-9 & $<0.00$ & 0.12 & 0.01 & 0.03 & 0.07 & $<0.00$ \\
\hline 241-B-112 & $<0.00$ & 0.04 & 0.01 & 0.07 & 0.05 & $<0.00$ \\
\hline 241-BX-108 & $<0.00$ & 0.05 & 0.01 & 0.09 & 0.06 & $<0.00$ \\
\hline 241-BY-107 & $<0.00$ & 0.02 & 0.01 & 0.05 & 0.03 & $<0.00$ \\
\hline
\end{tabular}




\subsubsection{Waste Site 216-B-44}

This site operated during 1954 and 1955, receiving 5.6 ML of ferrocyanide waste as part of the scavenging campaign (Corbin et al. 2005). The estimated inventories of plutonium-239/240 and americium-241 are $4.94 \mathrm{Ci}$ and $9.33 \mathrm{Ci}$, respectively (Table 3.6). References used to determine the contributing volumes are located in Appendix A of Corbin et al. (2005).

\subsubsection{Waste Site 216-B-45}

This site operated during 1955, receiving 4.91 ML of ferrocyanide waste as part of the scavenging campaign (Corbin et al. 2005). The estimated inventories of plutonium-239/240 and americium-241 are 4.43 Ci and 8.19 Ci, respectively (Table 3.6). References used to determine the contributing volumes are located in Appendix A of Corbin et al. (2005).

\subsubsection{Waste Site 216-B-46}

This site operated during 1955, receiving 6.7 ML of ferrocyanide waste as part of the scavenging campaign (Corbin et al. 2005). The estimated inventories of plutonium-239/240 and americium-241 are $5.90 \mathrm{Ci}$ and $11.2 \mathrm{Ci}$, respectively (Table 3.6). References used to determine the contributing volumes are located in Appendix A of Corbin et al. (2005).

\subsubsection{Waste Site 216-B-47}

This site operated during 1955, receiving 3.68 ML of ferrocyanide waste as part of the scavenging campaign (Corbin et al. 2005). The estimated inventories of plutonium-239/240 and americium-241 are $3.25 \mathrm{Ci}$ and $6.13 \mathrm{Ci}$, respectively (Table 3.6). References used to determine the contributing volumes are located in Appendix A of Corbin et al. (2005).

\subsubsection{Waste Site 216-B-48}

This site operated during 1955, receiving 4.09 ML of ferrocyanide waste as part of the scavenging campaign (Corbin et al. 2005). The estimated inventories of plutonium-239/240 and americium-241 are 3.60 $\mathrm{Ci}$ and $6.81 \mathrm{Ci}$, respectively (Table 3.6). References used to determine the contributing volumes are located in Appendix A of Corbin et al. (2005).

\subsubsection{Waste Site 216-B-49}

This site operated during 1955, receiving 6.7 ML of ferrocyanide waste as part of the scavenging campaign (Corbin et al. 2005). The estimated inventories of plutonium-239/240 and americium-241 are $5.90 \mathrm{Ci}$ and $11.2 \mathrm{Ci}$, respectively (Table 3.6). References used to determine the contributing volumes are located in Appendix A of Corbin et al. (2005). 


\subsubsection{Waste Site 216-B-7A\&B}

This site operated during 1946-1954 and 1966-1967. The site received 44.6 ML of a variety of wastes over its operating history (Corbin et al. 2005). The estimated inventories of plutonium-239/240 and americium-241 are $28.5 \mathrm{Ci}$ and $5.62 \mathrm{Ci}$, respectively (Table 3.6). References used to determine the contributing volumes are located in Appendix A of Corbin et al. (2005).

Characterization of the 216-B-7A Crib reported to date include geophysical logging of six boreholes/ wells (C3103, 299-E33-18, 299-E33-58, 299-E33-59, 299-E33-60, and 299-E33-75) (DOE/RL 2007b). Sediment samples also were collected from borehole C3103 for laboratory analysis. Results from the sediment sample analyses from borehole C3103 indicated that a maximum in plutonium-239/240 concen-

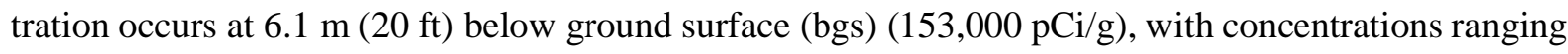
from 153,000 to 1,360 pCi/g in the depth interval of 5.5 and $11.4 \mathrm{~m}$ (18 and $37.5 \mathrm{ft}$ ) bgs (DOE/RL 2003). Plutonium-238 was measured at $140 \mathrm{pCi} / \mathrm{g}$ in the depth interval of 5.5 and $11.4 \mathrm{~m}$ (18 and $37.5 \mathrm{ft}) \mathrm{bgs}$. Americium-241 concentrations ranged from 5,690 to $21.8 \mathrm{pCi} / \mathrm{g}$ in the depth interval of 5.5 to $11.4 \mathrm{~m}$ (18 to $37.5 \mathrm{ft}$ ) bgs.

Lindenmeier et al. (2002) summarize geologic, geochemical, and selected physical characterization data collected on vadose zone sediment recovered from borehole C3103 (216-B-7A Crib), a few sediment samples from C3104 (216-B-38 Trench), and supplemental data provided from borehole C3104 reported by Bechtel Hanford, Inc. in Todd and Trice (2002). Detectable plutonium was found in borehole C3104 sediment samples in the depth interval of 4.42 to $9.60 \mathrm{~m}(14.5$ to $31.5 \mathrm{ft})$ bgs. The highest concentration was measured in a sample collected from the depth interval of 5.49 to $6.25 \mathrm{~m}$ (18 to $20.5 \mathrm{ft}$ ) bgs at 159 pCi/g (plutonium 239/240).

\subsubsection{Waste Site 216-B-8}

This site operated during 1948-1953. The site received approximately 35.3 ML of 224 (lanthanum fluoride process 224 Building waste) and 5-6 waste (a miscellaneous waste stream) (Corbin et al. 2005). The estimated inventories of plutonium-239/240 and americium-241 are $136 \mathrm{Ci}$ and $1.12 \mathrm{Ci}$, respectively (Table 3.6). References used to determine the contributing volumes are located in Appendix A of Corbin et al. (2005).

With the exception of spectral gamma logging (DOE/GJO 2002), the 216-B-8 Crib has not been characterized (DOE/RL 2003; DOE/RL 2007b). Spectral gamma logging performed in boreholes in the vicinity of the 216-B-8 Crib indicated that cesium-137 was the predominant radioactive contaminant, and plutonium and americium radionuclides were not detected (DOE/GJO 2002). The 216-B-7A Crib has been selected as a representative waste site for the 216-B-8 Crib (DOE/RL 2003; DOE/RL 2007b). The 216-B-7B Crib is included with the 216-B-7A Crib because the sites are duplicates, located next to each other, and accepted the same waste stream; however, only the 216-B-7A Crib has been characterized.

\subsubsection{Waste Site 241-BX-101}

The 241-BX-101 tank leak event occurred in 1972. A total volume of 15,140 L (4,000 gal) of Sr-Cs Rec Org Wst aqu (P2)_BL waste (Corbin et al. 2005). The estimated inventories of plutonium-239/240 and americium-241 are $0.11 \mathrm{Ci}$ and $1.05 \mathrm{Ci}$, respectively (Table 3.6). 


\subsubsection{Waste Site 241-BX-102}

The 241-BX-102 tank leak event occurred in 1951. This overfill loss consisted of a total volume of 346,706 L (91,600 gal). The waste composition includes $\mathrm{MW} 1$ [ $\mathrm{BiPO}_{4}$ metal waste (1944-1949)] solids that were added to the MW1 (BT1) waste stream to reach estimated uranium values matching the historical descriptions of event (Corbin et al. 2005). The estimated inventories of plutonium-239/240 and americium-241 are $1.42 \mathrm{Ci}$ and $0.28 \mathrm{Ci}$, respectively (Table 3.6).

\subsection{B Plant Zone}

Waste sites in the B Plant zone and associated quantities (curies) of plutonium, americium, and neptunium nuclides disposed (decayed to January 1, 2001) are listed in Table 3.7. Two sites in this closure zone received plutonium-239 or americium-241 above 1.0 Ci (216-B-5 and UPR-200-E-87).

Table 3.7. B Plant Zone Waste Sites and Associated Quantities of Plutonium, Americium, and Neptunium Nuclides Disposed (Ci), Decayed to January 1, 2001

\begin{tabular}{lrrrrrr}
\hline \multicolumn{1}{c}{ Waste Site } & Pu-238 & Pu-239 & Pu-240 & Pu-241 & Am-241 & Np-237 \\
\hline 216-B-10A & $<0.00$ & $<0.00$ & $<0.00$ & $<0.00$ & $<0.00$ & $<0.00$ \\
216-B-10B & $<0.00$ & $<0.00$ & $<0.00$ & $<0.00$ & $<0.00$ & $<0.00$ \\
216-B-12 & $<0.00$ & 0.19 & 0.02 & 0.05 & 0.05 & $<0.00$ \\
216-B-13 & $<0.00$ & $<0.00$ & $<0.00$ & $<0.00$ & $<0.00$ & $<0.00$ \\
216-B-4 & $<0.00$ & $<0.00$ & $<0.00$ & $<0.00$ & $<0.00$ & $<0.00$ \\
216-B-5 & 0.13 & 37.2 & 2.51 & 2.41 & 0.12 & 0.01 \\
216-B-55 & $<0.00$ & $<0.00$ & $<0.00$ & $<0.00$ & $<0.00$ & $<0.00$ \\
216-B-59 & $<0.00$ & $<0.00$ & $<0.00$ & $<0.00$ & $<0.00$ & $<0.00$ \\
216-B-6 & $<0.00$ & $<0.00$ & $<0.00$ & $<0.00$ & $<0.00$ & $<0.00$ \\
216-B-60 & 0.01 & 0.06 & 0.02 & 0.42 & $<0.00$ & $<0.00$ \\
216-B-62 & 0.01 & 0.17 & 0.04 & 0.23 & 0.22 & 0.01 \\
UPR-200-E-1 & $<0.00$ & 0.11 & 0.01 & 0.01 & $<0.00$ & $<0.00$ \\
UPR-200-E-3 & $<0.00$ & $<0.00$ & $<0.00$ & $<0.00$ & $<0.00$ & $<0.00$ \\
UPR-200-E-7 & $<0.00$ & $<0.00$ & $<0.00$ & $<0.00$ & $<0.00$ & $<0.00$ \\
UPR-200-E-77 & $<0.00$ & $<0.00$ & $<0.00$ & $<0.00$ & $<0.00$ & $<0.00$ \\
UPR-200-E-80 & $<0.00$ & $<0.00$ & $<0.00$ & $<0.00$ & $<0.00$ & $<0.00$ \\
UPR-200-E-84 & $<0.00$ & $<0.00$ & $<0.00$ & $<0.00$ & $<0.00$ & $<0.00$ \\
UPR-200-E-85 & $<0.00$ & 0.01 & $<0.00$ & 0.02 & $<0.00$ & $<0.00$ \\
UPR-200-E-87 & 0.01 & 2.58 & 0.17 & 0.17 & $<0.00$ & $<0.00$ \\
\hline
\end{tabular}

\subsubsection{Waste Site 216-B-5}

This site received a total of $32 \mathrm{ML}$ of 224 and 5-6 waste from the bismuth phosphate process during 1945-1947 (Corbin et al. 2005). The estimated inventories of plutonium-239/240 and americium-241 are $39.7 \mathrm{Ci}$ and $0.12 \mathrm{Ci}$, respectively (Table 3.7). Waste Site 216-B-5 is a reverse well designed and 
constructed to dispose of intermediate-level liquid wastes from the bismuth phosphate separation process originating from B Plant, deep in the vadose zone or directly into the groundwater.

To determine the extent of contamination associated with this site, a characterization study was conducted by Smith (1980). As part of this study, three wells were drilled and another was extended in the vicinity of the 216-B-5 Reverse Well. Analytical results from borehole sediments collected during drilling of these wells indicated that plutonium-239/240 concentrations greater than 10,000 pCi/g were limited to within $6 \mathrm{~m}$ (20 ft) of the reverse well. Concentrations of plutonium-239/240 greater than $100,000 \mathrm{pCi} / \mathrm{g}$ were limited to a narrow (1-m [3.3-ft]) layer located at the depth of the 1948 water table. The sample with the highest reported plutonium-239/240 concentration $(75,000 \mathrm{pCi} / \mathrm{g})$ was from Well 299-E28-23 (located $1 \mathrm{~m}$ [3.3 ft]) from the reverse well) at a depth of $88.1 \mathrm{~m}$ (289 ft). The highest americium-241 concentration reported (2,540 pCi/g) was also from this well at a depth of $89.5 \mathrm{~m}(294 \mathrm{ft})$.

As part of the 216-B-5 Reverse Well Characterization Study (Smith 1980), plutonium analyses were conducted on sludge in the 241-B-361 Settling Tank. These results indicated that approximately half of the $4.3 \mathrm{~kg}$ of plutonium released to the system was retained in the 241-B-361 Settling Tank, and the remainder was discharged into the 216-B-5 Reverse Well.

In addition to the direct radiochemical analysis of the sediment samples collected for the Smith study (1980), borehole logging with scintillation and spectral gamma spectroscopy for a number of boreholes located within the 200-TW-1 and 200-TW-2 Operable Units has also been conducted. These analyses are not sufficiently sensitive to estimate in situ plutonium and americium concentrations due to the high concentrations of cesium-137 and other radioactive contaminants that are also generally associated with plutonium and americium contaminated sediments.

In 1976, plutonium was measured in groundwater from three wells located near the 216-B-5 Reverse Well using a large-volume sampling technique (Weimer 1978). The wells sampled were 299-E28-1, 299-E28-5, and 299-E28-7 located approximately 180 m (590ft), $290 \mathrm{~m}$ (951ft), and $20 \mathrm{~m}$ (66 ft), respectively, from the 216-B-5 Reverse Well. The sample collected from Well 299-E28-7 contained the highest concentration of plutonium-239/240 (0.16 pCi/L). Wells 299-E28-1 and 299-E28-5 had considerably lower concentrations at $0.0005 \mathrm{pCi} / \mathrm{L}$ and $0.0008 \mathrm{pCi} / \mathrm{L}$.

Plutonium-239/240 has been detected in past years in samples collected from several wells near the 216-B-5 Injection Well (DOE/RL 2008). The highest reported plutonium concentration in fiscal year (FY) 2006 was from Well 299-E28-23 that had reported filtered values of 12.0 and $12.7 \mathrm{pCi} / \mathrm{L}$ and unfiltered values of 35.4 and $40.4 \mathrm{pCi} / \mathrm{L}$. The lower concentrations in the filtered samples suggest that some of the plutonium is associated with filterable particulates. Plutonium concentrations in Well 299-E-28-23 have not exhibited a clear change in trend in recent years. Other wells sampled near the 216-B-5 Injection Well site have also had plutonium levels below the DOE-derived concentration guide $(30 \mathrm{pCi} / \mathrm{L})$ in recent years.

\subsubsection{UPR-200-E-87}

This UPR occurred in 1949 and consisted of 2,937 L (7,660 gal) of 224 (BT1) waste (Corbin et al. 2005). The estimated inventories of plutonium-239/240 and americium-241 are $2.75 \mathrm{Ci}$ and $<0.00 \mathrm{Ci}$, respectively (Table 3.7). 


\subsection{NRDWL-BC Control Zone}

Waste sites in the NRDWL-BC control zone and associated quantities of plutonium, americium, and neptunium nuclides disposed (Ci) (decayed to January 1, 2001) are listed in Table 3.8. Twenty-three sites in this closure zone received plutonium-239 or americium-241 above $1.0 \mathrm{Ci}$. All the sites in this control zone, with the exception of 216-B-53A, received ferrocyanide waste as part of the scavenging campaign in 1956-1957 (Corbin et al. 2005).

Table 3.8. NRDWL-BC Control Zone Waste Sites and Associated Quantities of Plutonium, Americium, and Neptunium Nuclides Disposed (Ci), Decayed to January 1, 2001

\begin{tabular}{lcccccc}
\hline \multicolumn{1}{c}{ Waste Site } & Pu-238 & Pu-239 & Pu-240 & Pu-241 & Am-241 & Np-237 \\
\hline $216-B-14$ & 0.05 & 6.90 & 0.74 & 1.45 & 14.4 & 0.26 \\
$216-B-15$ & 0.04 & 5.03 & 0.54 & 1.06 & 10.5 & 0.19 \\
$216-B-16$ & 0.03 & 4.45 & 0.49 & 0.97 & 8.83 & 0.16 \\
$216-B-17$ & 0.02 & 2.71 & 0.31 & 0.63 & 4.65 & 0.08 \\
$216-B-18$ & 0.05 & 6.78 & 0.73 & 1.43 & 14.2 & 0.26 \\
$216-B-19$ & 0.04 & 5.05 & 0.56 & 1.14 & 9.25 & 0.16 \\
$216-B-20$ & 0.03 & 3.83 & 0.42 & 0.86 & 6.94 & 0.12 \\
$216-B-21$ & 0.03 & 3.72 & 0.40 & 0.79 & 7.58 & 0.14 \\
$216-B-22$ & 0.03 & 3.77 & 0.41 & 0.82 & 7.34 & 0.13 \\
$216-B-23$ & 0.03 & 3.59 & 0.39 & 0.79 & 6.99 & 0.12 \\
$216-B-24$ & 0.03 & 3.87 & 0.41 & 0.81 & 8.11 & 0.15 \\
$216-B-25$ & 0.03 & 3.91 & 0.42 & 0.82 & 8.18 & 0.15 \\
$216-B-26$ & 0.03 & 3.86 & 0.42 & 0.81 & 7.91 & 0.14 \\
$216-B-27$ & 0.03 & 3.52 & 0.38 & 0.74 & 7.36 & 0.13 \\
$216-B-28$ & 0.03 & 4.02 & 0.44 & 0.87 & 7.89 & 0.14 \\
$216-B-29$ & 0.03 & 3.84 & 0.41 & 0.81 & 8.05 & 0.15 \\
$216-B-30$ & 0.03 & 3.81 & 0.42 & 0.86 & 6.92 & 0.12 \\
$216-B-31$ & 0.03 & 3.86 & 0.43 & 0.88 & 7.03 & 0.12 \\
$216-B-32$ & 0.03 & 3.78 & 0.42 & 0.86 & 6.83 & 0.12 \\
$216-B-33$ & 0.03 & 3.77 & 0.42 & 0.87 & 6.63 & 0.12 \\
$216-B-34$ & 0.03 & 3.87 & 0.44 & 0.90 & 6.79 & 0.12 \\
$216-B-52$ & 0.05 & 6.78 & 0.76 & 1.55 & 12.1 & 0.21 \\
$216-B-53 A$ & 0.32 & 2.86 & 1.00 & 18.6 & 0.31 & $<0.00$ \\
$216-B-53 B$ & 0.09 & 0.82 & 0.29 & 5.44 & 0.01 & $<0.00$ \\
$216-B-54$ & 0.10 & 0.98 & 0.32 & 5.76 & 0.55 & $<0.00$ \\
$216-B-58$ & 0.08 & 0.72 & 0.25 & 4.49 & 0.23 & $<0.00$ \\
\hline
\end{tabular}

\subsubsection{Waste Site 216-B-53A}

This site received approximately 550,000 L (132,100 gal) of 300 Area laboratory waste mixed with wastes released from the former Plutonium Recycle Test Reactor during 1965 (Corbin et al. 2005). The 222-S Laboratory and PL1 wastes were selected as the most appropriate representation of this waste disposal. The estimated inventories of plutonium-239/240 and americium-241 are 3.86 Ci and $0.31 \mathrm{Ci}$, respectively (Table 3.8). 


\subsection{PFP Zone}

Waste sites in the PFP zone and associated quantities of plutonium, americium, and neptunium nuclides disposed (Ci) (decayed to January 1, 2001) are listed in Table 3.9. Fourteen sites in this closure zone received plutonium-239 or americium-241 above $1.0 \mathrm{Ci}$.

Table 3.9. PFP Waste Sites and Associated Quantities of Plutonium, Americium, and Neptunium Nuclides Disposed (Ci), Decayed to January 1, 2001

\begin{tabular}{lcccccc}
\hline \multicolumn{1}{c}{ Waste Site } & Pu-238 & Pu-239 & Pu-240 & Pu-241 & Am-241 & Np-237 \\
\hline $216-Z-1 \& 2$ & 9.93 & 147 & 36.7 & 521 & 188 & 0.50 \\
$216-Z-10$ & 0.05 & 14.3 & 0.97 & 0.93 & 185 & 0.02 \\
$216-Z-12$ & 172 & 2,480 & 672 & 8,910 & 8,510 & 10.8 \\
$216-Z-13$ & $<0.00$ & $<0.00$ & $<0.00$ & $<0.00$ & $<0.00$ & $<0.00$ \\
$216-Z-14$ & $<0.00$ & $<0.00$ & $<0.00$ & $<0.00$ & $<0.00$ & $<0.00$ \\
$216-Z-15$ & $<0.00$ & $<0.00$ & $<0.00$ & $<0.00$ & $<0.00$ & $<0.00$ \\
$216-Z-16$ & 0.23 & 2.75 & 0.82 & 12.4 & 2.75 & 0.01 \\
$216-Z-17$ & 0.08 & 0.99 & 0.30 & 4.48 & 0.99 & $<0.00$ \\
$216-Z-18$ & 151 & 1,770 & 532 & 8,012 & 755 & 6.86 \\
$216-Z-1 A^{\text {(a) }}$ & 272 & 3,190 & 956 & 14,400 & 3,890 & 12.3 \\
$216-Z-20$ & 0.19 & 2.24 & 0.67 & 10.1 & 0.54 & 0.01 \\
$216-Z-21$ & $<0.00$ & $<0.00$ & $<0.00$ & $<0.00$ & $<0.00$ & $<0.00$ \\
$216-Z-3$ & 1.24 & 121 & 14.1 & 39.6 & 5,230 & 0.43 \\
$216-Z-4$ & $<0.00$ & 0.66 & 0.04 & 0.04 & 7.60 & $<0.00$ \\
$216-Z-5$ & 0.10 & 29.6 & 2.00 & 1.93 & 1,180 & 0.05 \\
$216-Z-6$ & 0.01 & 1.45 & 0.10 & 0.09 & 18.7 & $<0.00$ \\
$216-Z-7$ & 4.04 & 505 & 40.0 & 172 & 7,350 & 0.78 \\
$216-Z-8$ & 0.05 & 2.78 & 0.05 & 1.84 & 0.67 & 0.02 \\
$216-Z-9$ & 30.8 & 1,880 & 302 & 1,060 & 565 & 9.89 \\
UPR-200-W-130 & $<0.00$ & $<0.00$ & $<0.00$ & $<0.00$ & $<0.00$ & $<0.00$ \\
UPR-200-W-74 & $<0.00$ & $<0.00$ & $<0.00$ & $<0.00$ & $<0.00$ & $<0.00$ \\
\hline
\end{tabular}

(a) This site includes legacy sites 216-Z-1AA, AB, and AC.

\subsubsection{Waste Site 216-Z-1\&2}

The 216-Z-1 and 216-Z-2 Cribs are wooden timber structures that were used for disposal of Z Plant liquid waste (DOE/RL 2007a). The 216-Z-2 Crib overflowed into the 216-Z-1 Crib, which overflowed into the 216-Z-1A Tile Field. The site received approximately $34 \mathrm{ML}$ of plutonium recovery, americium recovery, and Z Complex laboratory waste during its operating lifetime (Corbin et al. 2005). The estimated inventories of plutonium-239/240 and americium-241 are $184 \mathrm{Ci}$ and $188 \mathrm{Ci}$, respectively (Table 3.9). The site operated 1949-1952 and 1966-1969. From 1949 to 1952, the cribs received basic (pH 8 to 10) process and laboratory waste from the 234-5Z Building via the 241-Z-361 Settling Tank. The cribs received acidic ( $\mathrm{pH} 1$ to 2.5), high-salt aqueous, and organic wastes directly from the 236-Z and 242-Z Buildings during two brief periods of a few weeks in 1966 and 1967, while the 216-Z-1A Tile Field discharge point was being moved further south along the main distribution pipe. The cribs received uranium wastes directly from the 236-Z Building from 1968 to 1969. 
Site-specific sampling data for the 216-Z-1 and 216-Z-2 Cribs are limited (DOE/RL 2007a). A borehole north of the 216-Z-2 Crib (299-W18-172) was logged using geophysical techniques in 2006. No manmade radionuclides were detected. In addition, no radionuclide contamination was detected during drilling of a new well (299-W18-253) west of the cribs in 2006. In 1986, drop cords, visual inspection, and foil activation methods were used to evaluate alpha contamination in 11 wells at the 216-Z-1 and 216-Z-2 Cribs and the 216-Z-1A Tile Field (CNN 65632-86-095 1986). Wells 299-W18-60, 299-W18-61, and 299-W18-65 near the 216-Z-1 and 216-Z-2 Cribs were found to contain plutonium and americium concentrations estimated to be as high as $900 \mathrm{nCi} / \mathrm{g}$. The contamination was believed to have resulted from contaminated sediments entering and accumulating in the wells.

\subsubsection{Waste Site 216-Z-10}

The 216-Z-10 Injection/Reverse Well (Well 299-W15-51) is a liquid waste disposal site that was used during 1945 to dispose of process and laboratory waste from the 231-Z Building via the 231-W-151 Sump (DOE/RL 2007a). The site received $1 \mathrm{ML}$ of plutonium recovery waste and Z Complex laboratory (Corbin et al. 2005). The estimated inventories of plutonium-239/240 and americium-241 are $15.3 \mathrm{Ci}$ and $185 \mathrm{Ci}$, respectively (Table 3.9). The waste was released to the sediment through perforations in the well casing in the depth interval of 33 to $46 \mathrm{~m}$ (108 to $150 \mathrm{ft}$ ) bgs.

Site characterization data include geophysical logging and analytical soil samples taken every $1.5 \mathrm{~m}$ (5 ft) from three characterization wells surrounding the 216-Z-10 Injection/Reverse Well in an approximate 4.6-m (15-ft) radius and extending about $7.6 \mathrm{~m}$ (25 ft) deeper than the 216-Z-10 well. Soil samples did not find plutonium contamination above a detection limit of approximately $0.15 \mathrm{pCi} / \mathrm{g}$ (Wolff 1952), indicating that contamination had spread laterally less than $4.6 \mathrm{~m}$ (15 ft) (Brown and Ruppert 1948).

\subsubsection{Waste Site 216-Z-12}

The 216-Z-12 Crib is a subsurface liquid waste site that was used from 1959 to 1973 to dispose of PFP liquid process waste and analytical and development laboratory waste from the 234-5Z Building via the 241-Z-361 Settling Tank (DOE/RL 2007a). The site received about 272 ML of plutonium purification, 232-Z Incinerator, and Z Complex laboratory waste (Corbin et al. 2005). The waste was low-salt neutral to basic ( $\mathrm{pH} 8$ to 10) when discharged. The estimated inventories of plutonium-239/240 and americium-241 are 3,152 Ci and 8,510 Ci, respectively (Table 3.9).

Early characterization activities have been summarized by Kasper (1982). Wells were drilled in and around the crib using specialized techniques for obtaining highly contaminated sediment samples. The highest plutonium concentrations were found in sediments immediately beneath the bottom of the crib at concentrations of 1 to $5 \mu \mathrm{Ci} / \mathrm{g}$. Plutonium concentrations decrease rapidly with distance from the bottom of the crib. Plutonium concentrations decreased to less than $1,000 \mathrm{pCi} / \mathrm{g}$ at $3 \mathrm{~m} \mathrm{(10} \mathrm{ft)} \mathrm{below} \mathrm{the} \mathrm{bottom}$

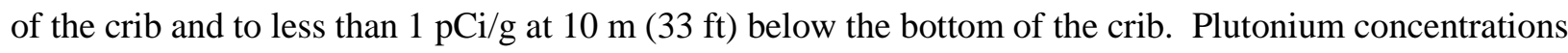
increased to a few tens of picocuries per gram at a depth of 30 to $36 \mathrm{~m}$ (98 to $118 \mathrm{ft}$ ) below the bottom of the crib. The increase in plutonium concentrations is associated with a silt unit at that depth. No measurable plutonium was found in groundwater beneath the 216-Z-12 Crib. 


\subsubsection{Waste Site 216-Z-16}

There are no records for estimates of annual or total volume available for this site. Estimates of the annual and total discharge volumes were made assuming an average of $2 \mathrm{~L}$ ( 0.53 gal) loss/minute throughout the operating history of the site. This assumption results in approximately $1 \mathrm{ML}$ of discharge per year or approximately $48 \mathrm{ML}$ of Z Complex stack drainage during its operating lifetime. The estimated inventories of plutonium-239/240 and americium-241 are $3.57 \mathrm{Ci}$ and $2.75 \mathrm{Ci}$, respectively (Table 3.9). The site operated from 1949 through 1997.

\subsubsection{Waste Site 216-Z-18}

The 216-Z-18 Crib was used as a replacement for the 216-Z-1A Tile Field to receive high-salt, acidic (pH 1 to 2.5) aqueous, and organic liquid wastes from PFP (DOE/RL 2007a). The waste streams included plutonium recovery waste from the 236-Z Building and americium recovery waste from the 242-Z Building. Carbon tetrachloride was received in the aqueous phase liquid and mixed with other organics as a dense, nonaqueous phase liquid (DNAPL). The site operated from 1969 through 1973 and received a total of $4 \mathrm{ML}$ of waste during that time (Corbin et al. 2005). The estimated inventories of plutonium-239/240 and americium-241 are 2,300 Ci and $755 \mathrm{Ci}$, respectively (Table 3.9).

Characterization activities of the 216-Z-18 Crib have been conducted since the 1960s (DOE/RL 2007a). Scintillation logging of site monitoring wells was conducted in 1968, 1973, and 1976. Wells 299-W18-9 and 299-W18-10 were the only wells with contamination above background levels. Contamination was found in the depth interval of 8 to $17 \mathrm{~m}$ (26 to $56 \mathrm{ft}$ ) bgs (Fecht et al. 1977). Characterization was also conducted in 1992 and 1993 in support of soil-vapor extraction activities. Spectral gamma logging and neutron moisture logging were conducted in 2006 in Wells 299-W18-9, 299-W18-12, and 299-W18-95. Plutonium and americium-241 were found in Well 299-W18-9 at depths of 7.6 to $18 \mathrm{~m}$

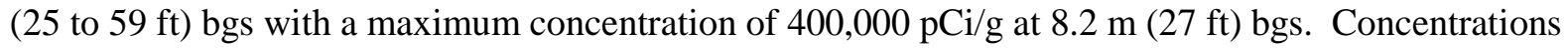

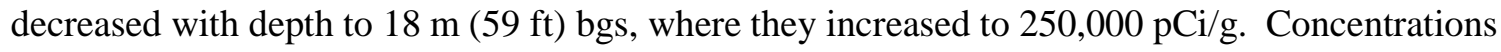
decreased to the tool detection limits below about $21 \mathrm{~m}$ (69 ft) bgs. Analytical soil data obtained from Wells 299-W18-96, 299-W18-247, and 299-W18-249 in 1992 and 1993 did not identify significant organic chemical contamination (e.g., carbon tetrachloride was $<2 \mathrm{ppm}$ ). Nitrate was found in Well 299-W18-96 at 4,400 mg/kg at $25.6 \mathrm{~m} \mathrm{(84} \mathrm{ft)} \mathrm{bgs} \mathrm{decreasing} \mathrm{to}<10 \mathrm{mg} / \mathrm{kg}$ at $38.1 \mathrm{~m}$ (125 ft) bgs. No significant concentrations of carbon tetrachloride or other volatile organic compounds were identified during soil-vapor sampling conducted for remedial investigation or soil-vapor extraction operations in 2005 or 2006.

\subsubsection{Waste Site 216-Z-1A}

The 216-Z-1A Tile Field was a liquid waste site that was used to dispose of aqueous and organic liquid waste generated at PFP (DOE/RL 2007a). The waste streams included overflow from the 216-Z-1, 216-Z-2, and 216-Z-3 Cribs, which received process and laboratory waste from 1949 to 1959 and 236-Z plutonium recovery waste and 242-Z americium recovery waste discharged directly to the tile field from 1964 to 1969. The wastes discharged between 1949 and 1959 consisted of 1.0 ML of slightly basic, aqueous waste. The wastes discharged between 1964 and 1969 consisted of 5.2 ML of high-salt, acidic liquid waste containing significant inventories of plutonium, and carbon tetrachloride. The estimated 
inventories of plutonium-239/240 and americium-241 are 4,150 Ci and 3,890 Ci, respectively (Table 3.9). Carbon tetrachloride was received as an aqueous phase liquid and as DNAPL mixed with other organics.

The site was deactivated in 1969 as a result of plugged facility discharge piping to the tile field when plutonium recovery waste was diverted to the 216-Z-18 Crib. Soil-vapor extraction has been ongoing at the site since 1992 to remove carbon tetrachloride from the vadose zone. This site also includes inventories from separately reported sites (216-Z-1AA, 216-Z-1AB, and 216-Z-1AC) consolidated with the 216-Z-1A Tile Field (Corbin et al. 2005).

Characterization activities have been ongoing at the 216-Z-1A Tile Field since early operations. The distribution of plutonium and americium was characterized at 16 wells at this site in the 1970s (Price et al. 1979). In addition, many of the wells in and around the tile field have been geophysically logged (Fecht et al. 1977; Fluor Hanford, Inc. 2008). Plutonium and americium were detected to depths of up to $37 \mathrm{~m}$ (121 ft), indicating that plutonium and americium transport was enhanced as a result of the disposal of co-contaminants that included carbon tetrachloride, tributyl phosphate (TBP), degradation products of TBP, and acidic liquid wastes.

Additional characterization was conducted in 1991-1993 to support soil-vapor extraction activities. As part of the remedial investigation, information gathered from additional characterization boreholes was used to evaluate the distribution of carbon tetrachloride and other organic contaminants.

\subsubsection{Waste Site 216-Z-20}

This site received approximately 4,200 ML of Z Complex chemical sewer waste, Z Complex cooling water, and plutonium recovery waste. The majority of the waste disposed is considered to be chemical sewer and cooling water. The estimated inventories of plutonium-239/240 and americium-241 are 2.91 Ci and 0.54 Ci, respectively (Table 3.9). This site operated during 1982-1995.

\subsubsection{Waste Site 216-Z-3}

The 216-Z-3 Crib is a liquid waste disposal site that was used from 1952 to 1959 as a replacement for the 216-Z-1 and 216-Z-2 Cribs for disposal of Z Plant neutral-basic liquid process and laboratory waste received via the 241-Z-361 Settling Tank (DOE/RL 2007a). Overflow from the crib went to the 216-Z-1A Tile Field. The site was deactivated by closing off the valve from the pipeline to the crib and plugging the overflow line to the 216-Z-1A Tile Field. This site received approximately $180 \mathrm{ML}$ of waste during operation (Corbin et al. 2005). The estimated inventories of plutonium-239/240 and americium-241 are $135 \mathrm{Ci}$ and 5,230 Ci, respectively (Table 3.9).

Characterization activities include geophysical logging of two boreholes drilled through the crib (DOE/RL 2007a). Results of the logging indicated that plutonium contamination exceeded 1,000,000 pCi/g plutonium from about 5.5 to $9 \mathrm{~m}$ (18 to $30 \mathrm{ft}$ ) bgs. Plutonium concentrations decreased rapidly below $9 \mathrm{~m}$. 


\subsubsection{Waste Site 216-Z-4}

This site received 11,000 L (2,602 gal) of Z Complex laboratory waste and 234 5Z waste during 1945 (Corbin et al. 2005). The estimated inventories of plutonium-239/240 and americium-241 are $0.70 \mathrm{Ci}$ and 7.60 Ci, respectively (Table 3.9).

\subsubsection{Waste Site 216-Z-5}

The 216-Z-5 Crib was a liquid waste disposal site that was used from 1945 to 1947 to dispose of 231 Building plutonium contaminated process waste from the 231-W-151 Vault (DOE/RL 2007a). The site ceased operations when sludge blocked the system, and waste was diverted to the 216-Z-7 Crib. The crib was deactivated by capping the inlet line from the vault. The site was stabilized in 1990 . The site received $31 \mathrm{ML}$ of waste during its operational period (Corbin et al. 2005). The estimated inventories of plutonium-239/240 and americium-241 are 31.6 Ci and 1,180 Ci, respectively (Table 3.9).

Eight wells were drilled around the first crib structure in 1947 to determine the plutonium distribution in soils around the 216-Z-5 Crib (Brown and Ruppert 1948). Analysis of sediment samples collected indicate that only $0.5 \mathrm{~g}$ of plutonium could be accounted for and that the remainder of the plutonium discharged to the crib likely remained directly beneath the bottom of the crib (Brown and Ruppert 1948). More recent geophysical logging of six of these wells conducted in 2005 (DOE/RL 2007a) supported the initial findings of Brown and Ruppert (1948).

\subsubsection{Waste Site 216-Z-6}

This site received 98,000 L (25,891 gal) of Z Complex laboratory waste and 234 ZZ waste during 1945 (Corbin et al. 2005). The estimated inventories of plutonium-239/240 and americium-241 are 1.55 Ci and 18.7 Ci, respectively (Table 3.9).

\subsubsection{Waste Site 216-Z-7}

This site received $80 \mathrm{ML}$ of Z Complex laboratory waste, plutonium recovery waste and decontamination waste (Corbin et al. 2005). The estimated inventories of plutonium-239/240 and americium-241 are $545 \mathrm{Ci}$ and 7,350 Ci, respectively (Table 3.9). The site operated during 1947-1957 and 1965-1966.

Early characterization to evaluate the nature and extent of contamination at the 216-Z-7 Crib includes scintillation and spectral gamma logging (DOE/RL 2002b). Spectral gamma logs, scintillation profiles, or both were collected in seven boreholes (299-W15-7, 299-W15-62, 299-W15-63, 299-W15-64, 299-W15-76, 299-W15-77, and 299-W15-78). Only borehole 299-W15-7 is located within the waste site boundary. Scintillation profiles from the seven boreholes were reported by Fecht et al. (1977). Data from borehole 299-W15-7 indicated that contamination occurs within the crib boundary at $7.3 \mathrm{~m}(24 \mathrm{ft})$ bgs to 
the water table, indicating that contaminated effluent has reached groundwater. Scintillation logs from adjacent boreholes suggest significant lateral spreading of contaminants, with contamination detected from 13 to $44 \mathrm{~m}$ (42 to $143 \mathrm{ft}$ ) bgs.

Boreholes 299-W15-7, 299-W15-63, 299-W15-64, 299-W15-76, and 299-W15-77 were logged with spectral gamma logging in 1995 (DOE/RL 2002b). The spectral gamma logging confirmed the vertical and lateral extent of contamination suggested by the scintillation log profiles. Only cobalt-60, cesium-137, and europium-154 were detected by spectral gamma logging.

More recent characterization of the 216-Z-7 Crib included a borehole (borehole C4183) drilled in 2004 (DOE/RL 2006). Laboratory analyses were conducted on the sediment samples collected from the borehole, and the borehole was geophysically logged in 2005. In addition, six direct-push holes were geophysically logged in 2005.

Spectral gamma logging detected cobalt-60, cesium-137, europium-154, and plutonium-239. Plutonium-239 was detected in two direct-push holes, from 4.0 to $5.8 \mathrm{~m}$ (13 to $19 \mathrm{ft}$ ) bgs, with a maximum concentration of $240,000 \mathrm{pCi} / \mathrm{g}$ at $5.0 \mathrm{~m}(16.5 \mathrm{ft})$ bgs. Laboratory analysis results of the sediment samples indicate a maximum plutonium-239/240 concentration between 5.3 and $6.1 \mathrm{~m}$ (17.5 to $20 \mathrm{ft}$ ) at $472,000 \mathrm{pCi} / \mathrm{g}$. The maximum plutonium-238 concentration was detected between 5.3 and $6.1 \mathrm{~m}$ (17.5 to $20 \mathrm{ft})$ at $5,770 \mathrm{pCi} / \mathrm{g}$. The maximum americium-241 concentration was detected between 5.3 and $6.1 \mathrm{~m}$ (17.5 to $20 \mathrm{ft}$ ) at $60,600 \mathrm{pCi} / \mathrm{g}$. For each of the three transuranic radionuclides discussed above, concentrations decrease dramatically with depth below the maximum.

\subsubsection{Waste Site 216-Z-8}

This site received 9,590 L (2,534 gal) of Z Complex stack drainage and plutonium recovery waste (Corbin et al. 2005). The majority of the waste disposed is considered to be stack drainage. The estimated inventories of plutonium-239/240 and americium-241 are $2.83 \mathrm{Ci}$ and $0.67 \mathrm{Ci}$, respectively (Table 3.9). This site operated during 1957 through 1961.

\subsubsection{Waste Site 216-Z-9}

The 216-Z-9 Trench is an enclosed, below-grade trench that was used from 1955 to 1962 for disposal of Z Plant Recovery of Uranium and Plutonium by Extraction (RECUPLEX) aqueous and organic liquid waste (DOE/RL 2007a). Over 4 ML of liquid wastes were disposed (Corbin et al. 2005). The estimated inventories of plutonium-239/240 and americium-241 are 2,180 Ci and $565 \mathrm{Ci}$, respectively (Table 3.9). Carbon tetrachloride was received in the aqueous phase liquid and mixed with other organics as a

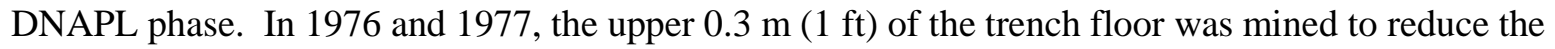
amount of plutonium in the trench. After mining, approximately 38 to $48 \mathrm{~kg}$ of plutonium are estimated to remain in soils beneath the trench. Soil-vapor extraction has been ongoing at the 216-Z-9 Trench since 1993 to remove carbon tetrachloride from the vadose zone.

Characterization of the site began in the 1950s, when wells were installed around the 216-Z-9 Trench to monitor contaminant migration. Many of the wells have been geophysically logged. Characterization was conducted in 1961, 1963, and 1973 to evaluate the plutonium and americium in the trench (Smith 1973). Characterization was conducted in 1991 to 1993 to support soil-vapor extraction activities. A 
DNAPL investigation conducted on the northeast corner of 216-Z-9 Trench in 1995 detected no DNAPL in Well 299-W15-32 (BHI 1995). Remedial investigation activities conducted at the trench included sampling from one deep well (299-W15-46), one slant well (299-W15-48), and a phased carbon

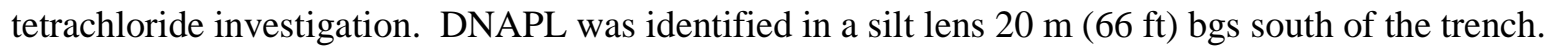

Plutonium and americium concentrations are greatest near the bottom of the trench and generally decrease with depth. However, both plutonium and americium have been detected at depths up to $36.7 \mathrm{~m}$ $(121 \mathrm{ft})$ bgs beneath the trench, indicating that plutonium and americium mobility was enhanced in the presence of the organic and acidic liquid wastes.

Low levels of plutonium and americium were detected in groundwater from Well 299-W15-8 on May 7, 1990 (8.3 pCi/L plutonium-239/240, 0.14 pCi/L americium-241), and November 13, 1991 (1.9 pCi/L plutonium-239/240, 5.9 pCi/L americium-241), before the groundwater table declined below the elevation of the bottom of the well and the well went dry.

\subsubsection{Summary of Soil Analysis Results from Wells 299-W15-46 and 299-W15-48 and Implications with Regard to Plutonium and Americium Mobility at the 216-Z-9 Trench}

Soil samples collected during the drilling of Wells 299-W15-46 and 299-W15-48 at the 216-Z-9 Trench were analyzed for a variety of contaminants. Results of the analyses are tabulated in Appendix B of the remedial investigation report (DOE/RL 2007a). The analysis of data for plutonium, americium, $\mathrm{TBP}, \mathrm{pH}$, and nitrate is discussed below.

Maximum concentration results for plutonium, americium, neptunium, and TBP and the lowest $\mathrm{pH}$ value, along with corresponding depth intervals for sediment samples collected during the drilling of Well 299-W15-46, are presented in Table 3.10. It is notable that the highest plutonium-239/240 result is coincident with both the highest TBP result and the lowest $\mathrm{pH}$ value measured. This suggests that plutonium-239/240 may have migrated through the vadose zone relatively unimpeded along with the organic and/or acidic high-salt aqueous waste streams. Neptunium-237 appears to have migrated significantly lower into the vadose zone than plutonium-239/240 or americium-241, but at much lower concentrations.

Plutonium, americium, and TBP concentration data are plotted as a function of average core depth below ground surface in Figure 3.2. The bottom of a silt layer that occurs at about $65 \mathrm{ft}$ bgs is indicated as well as the bottom of the Cold Creek unit at about $120 \mathrm{ft}$ bgs. High concentrations of plutonium, americium, and TBP occur at and above the bottom of the silt layer, indicating that plutonium migrated with co-contaminants during the operational period. It also appears that this upper silt layer has prevented significant vertical migration of TBP, plutonium, and americium below this layer (i.e., the concentration of TBP, plutonium, and americium just below the silt layer are significantly lower than concentrations observed within the silt layer). The same argument would appear to hold for americium in the Cold Creek unit. These results suggest that at this location, the upper silt layer and Cold Creek units are acting as significant barriers to further vertical migration of plutonium and americium. 
Table 3.10. Maximum Concentration and Depth Interval for Plutonium-239/240, Americium-241, Neptunium-237, TBP; and Lowest pH Value and Depth Interval, Well 299-W15-46

\begin{tabular}{lcrc}
\hline & Maximum & \multicolumn{2}{c}{ Depth Interval (ft bgs) } \\
\cline { 3 - 4 } Constituent or Parameter & Concentration & Top & Bottom \\
\hline Plutonium-239/240 & $115,000 \mathrm{pCi} / \mathrm{g}$ & 63.5 & 66 \\
Americium-241 & $324,000 \mathrm{pCi} / \mathrm{g}$ & 47.5 & 50 \\
Neptunium-237 & $28.9 \mathrm{pCi} / \mathrm{g}$ & 109.5 & 112 \\
TBP & $2,100 \mathrm{mg} / \mathrm{kg}$ & 63.5 & 66 \\
pH & 3.9 & 63.5 & 66 \\
\hline
\end{tabular}

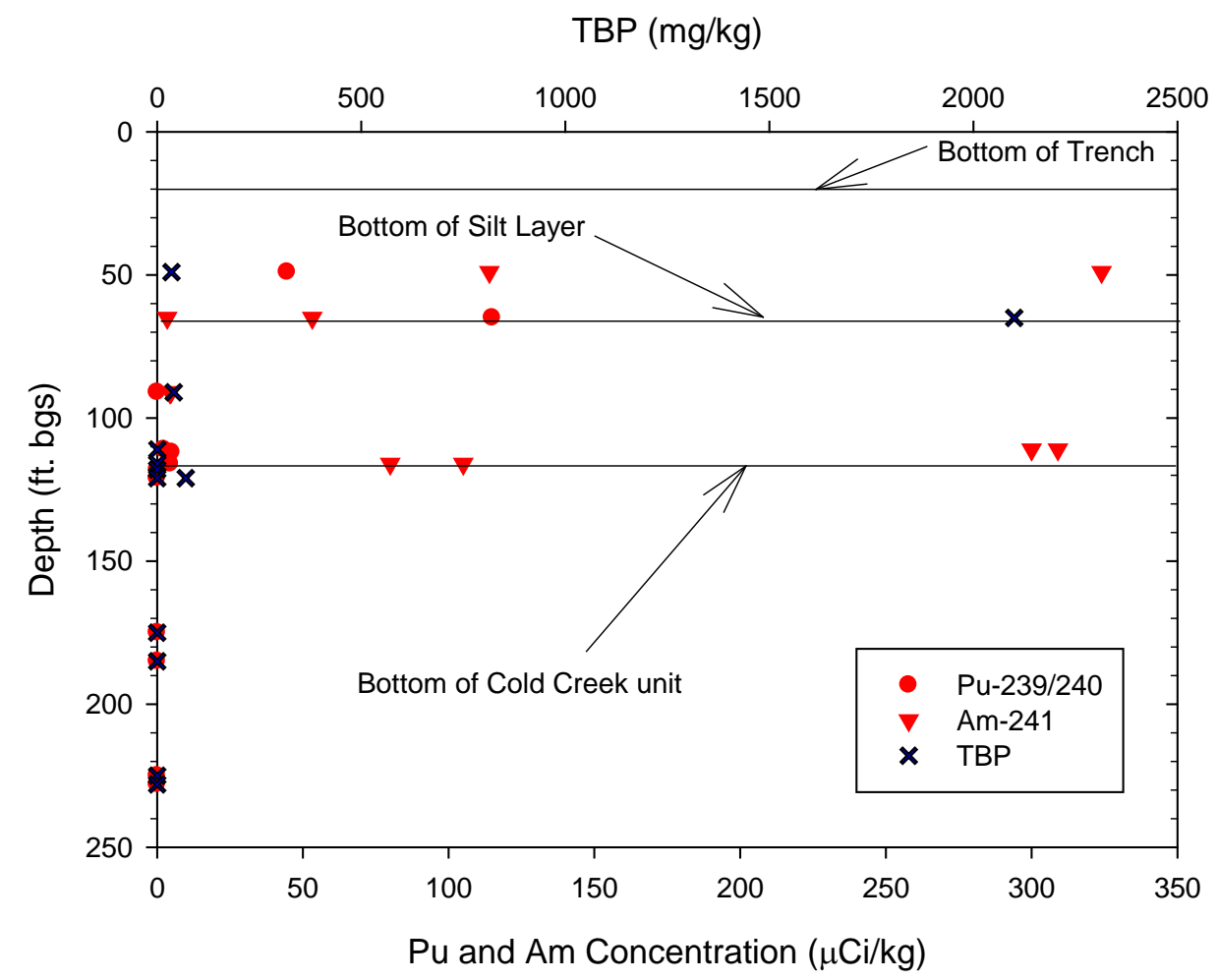

Figure 3.2. Plutonium, Americium, and TBP Concentrations as a Function of Depth Measured in Soil Samples from Well 299-W15-46

Plutonium, americium, and $\mathrm{pH}$ data as a function of average core depth below ground surface are shown in Figure 3.3. A number of low values of $\mathrm{pH}$ are indicated on this graph. A sample collected from the average core depth of $65 \mathrm{ft}$ bgs has a particularly low $\mathrm{pH}$ value of 3.9. Other low values of 6.0 and 6.6 are located at average core depths of $111 \mathrm{ft}$ bgs and $49 \mathrm{ft}$ bgs, respectively. These results suggest that significant impacts (e.g., loss of buffering capacity of the sediment) have occurred to sediment underlying the 216-Z-9 Trench as a result of acidic high-salt aqueous wastes. Impacts to the silt layer and Cold Creek unit also have occurred but apparently not sufficient to prevent attenuation of plutonium and americium to occur in these layers. High concentrations of americium occur above both the silt layer and the Cold Creek unit and at locations where values of $\mathrm{pH}$ are below neutral. 


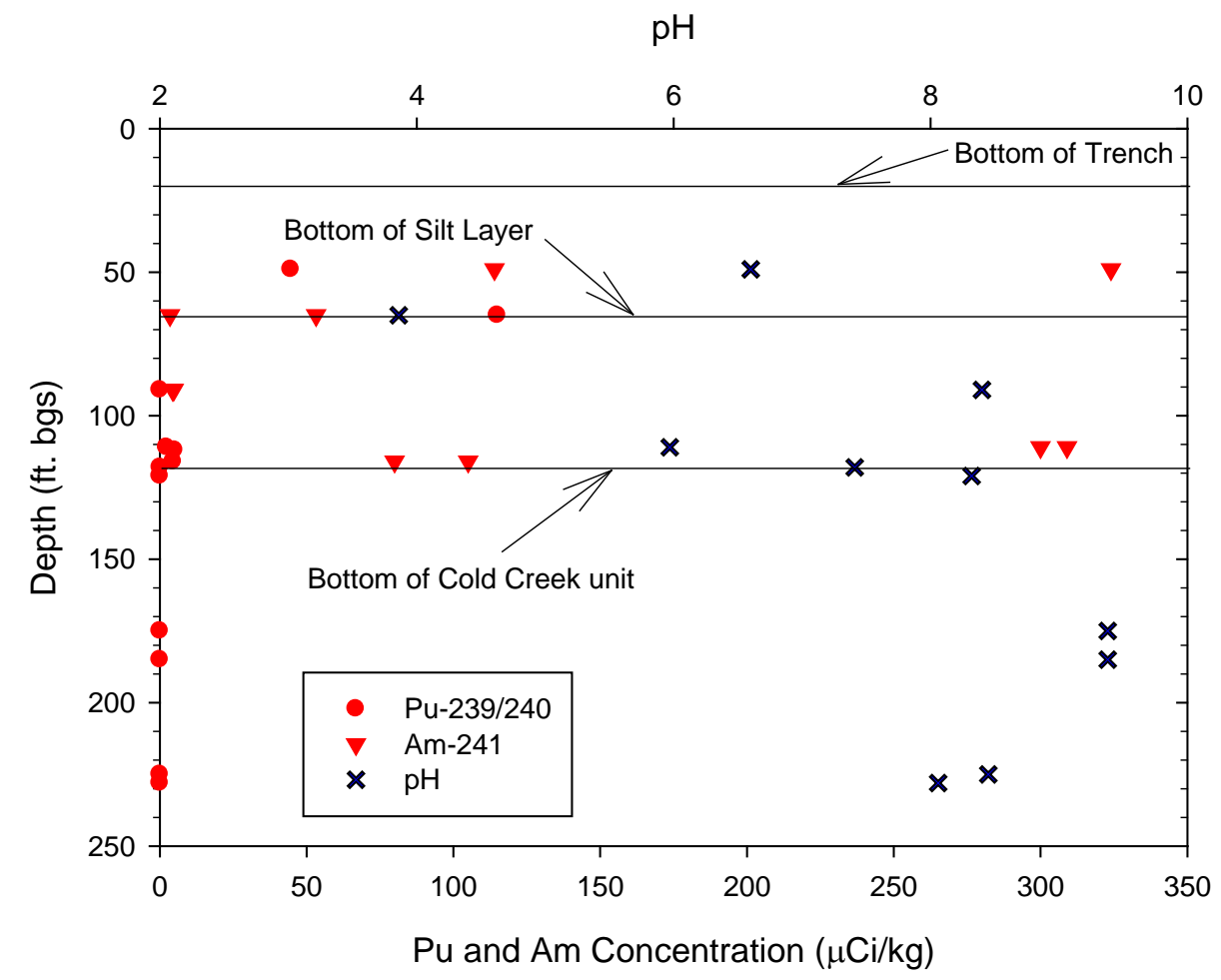

Figure 3.3. Plutonium, Americium, and $\mathrm{pH}$ as a Function of Depth Measured in Soil Samples from Well 299-W15-46

Nitrate data for Well 299-W15-46 as a function of average core depth bgs are shown in Figure 3.4. These data indicate that the acidic high-salt wastes disposed to the 216-Z-9 Trench traveled vertically down to the Cold Creek unit, where it encountered the calcium carbonate in the lower "caliche" layer. This layer appears to have been effective at buffering the acidic waste coming into contact with this layer and preventing significant further downward migration of the waste below the Cold Creek unit. It is assumed that lateral spreading of the acidic waste occurred above the silt layer and the Cold Creek unit at this location.

Maximum concentration results for plutonium, americium, neptunium, and TBP, along with the depth interval, for soil samples collected during the drilling of Well 299-W15-48 are presented in Table 3.11 No pH values are available for the Well 299-W15-48 soil samples. As was the case for Well 299-W15-46, data for Well 299-W15-48 indicate that the highest concentrations of plutonium and TBP occur at the same depth, indicating that plutonium migrated with co-contaminants during the operational period. Neptunium-237 appears to have migrated significantly lower into the vadose zone than plutonium239/240 but only slightly lower than americium-241. The highest neptunium-237 concentrations are much less than those of plutonium-239/240 and americium-241. 


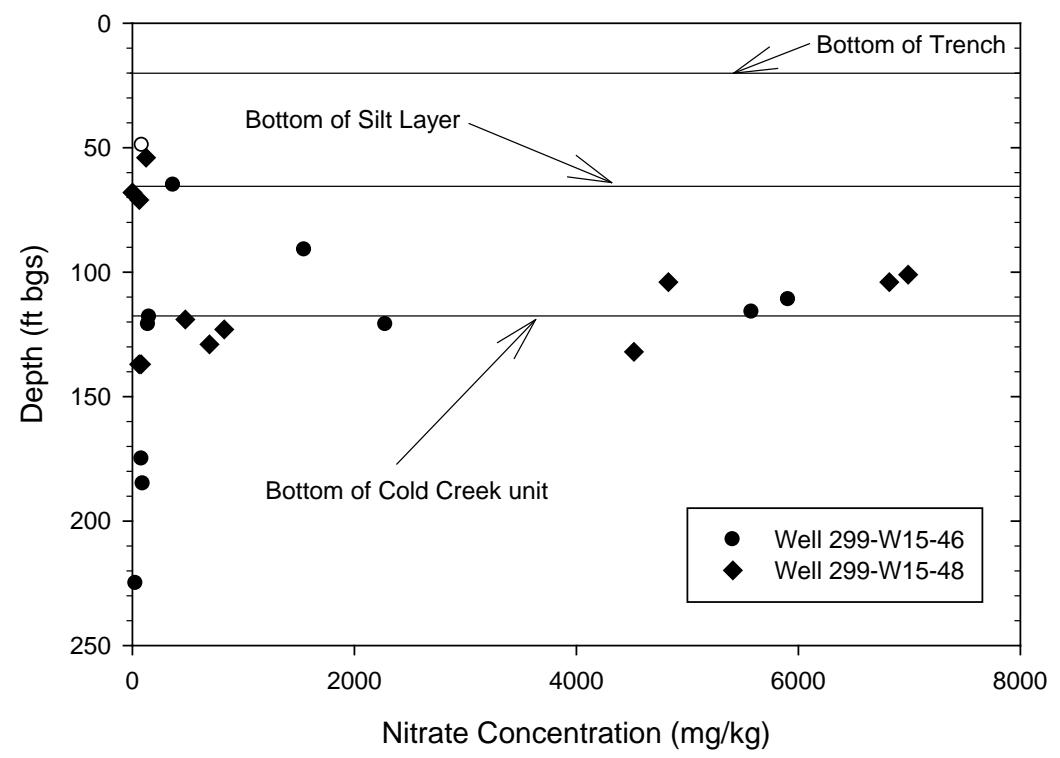

Figure 3.4. Nitrate Concentrations as a Function of Depth Measured in Soil Samples from Wells 299-W15-46 and 299-W15-48

Table 3.11. Maximum Concentration and Depth Interval for Plutonium-239/240, Americium-241, Neptunium-237, and TBP, Well 299-W15-48

\begin{tabular}{lccc}
\hline \multirow{2}{*}{$\begin{array}{c}\text { Radionuclide Contaminant } \\
\text { of Potential Concern }\end{array}$} & Maximum Concentration & Depth Interval (ft bgs) \\
\cline { 3 - 4 } & $254,000 \mathrm{pCi} / \mathrm{g}$ & 70 & Bottom \\
\hline Plutonium-239/240 & $131,000 \mathrm{pCi} / \mathrm{g}$ & 118.5 & 12 \\
Americium-241 & $10.5 \mathrm{pCi} / \mathrm{g}$ & 122.5 & 124.5 \\
Neptunium-237 & $3,000 \mathrm{mg} / \mathrm{kg}$ & 70 & 72 \\
TBP & & & \\
\hline
\end{tabular}

Plutonium, americium, and TBP concentration data for Well 299-W15-48 as a function of average core depth below ground surface are shown in Figure 3.5. These data are consistent with that of Well 299-W15-46, indicating that vertical migration of TBP and associated plutonium appears to have been slowed significantly (i.e., highly attenuated) within the silt layer located above $65 \mathrm{ft}$ bgs. Attenuation of some of the americium also occurred in this layer. The acidic high-salt component of the aqueous waste stream was able to breach this layer and continue its downward migration to the Cold Creek unit, carrying with it americium and a small amount of the plutonium in the waste. Americium and a small amount of plutonium showed attenuation within and at the bottom of the Cold Creek unit. Vertical migration of plutonium and americium appears to have been stopped below the Cold Creek unit where plutonium and americium concentrations are low. This layer appears to have been effective at buffering the acidic waste coming into contact with this layer (see Figure 3.3) and preventing significant further downward migration of the waste below the Cold Creek unit. It is assumed that lateral spreading of the acidic waste occurred above the silt layer and the Cold Creek unit at this location. 


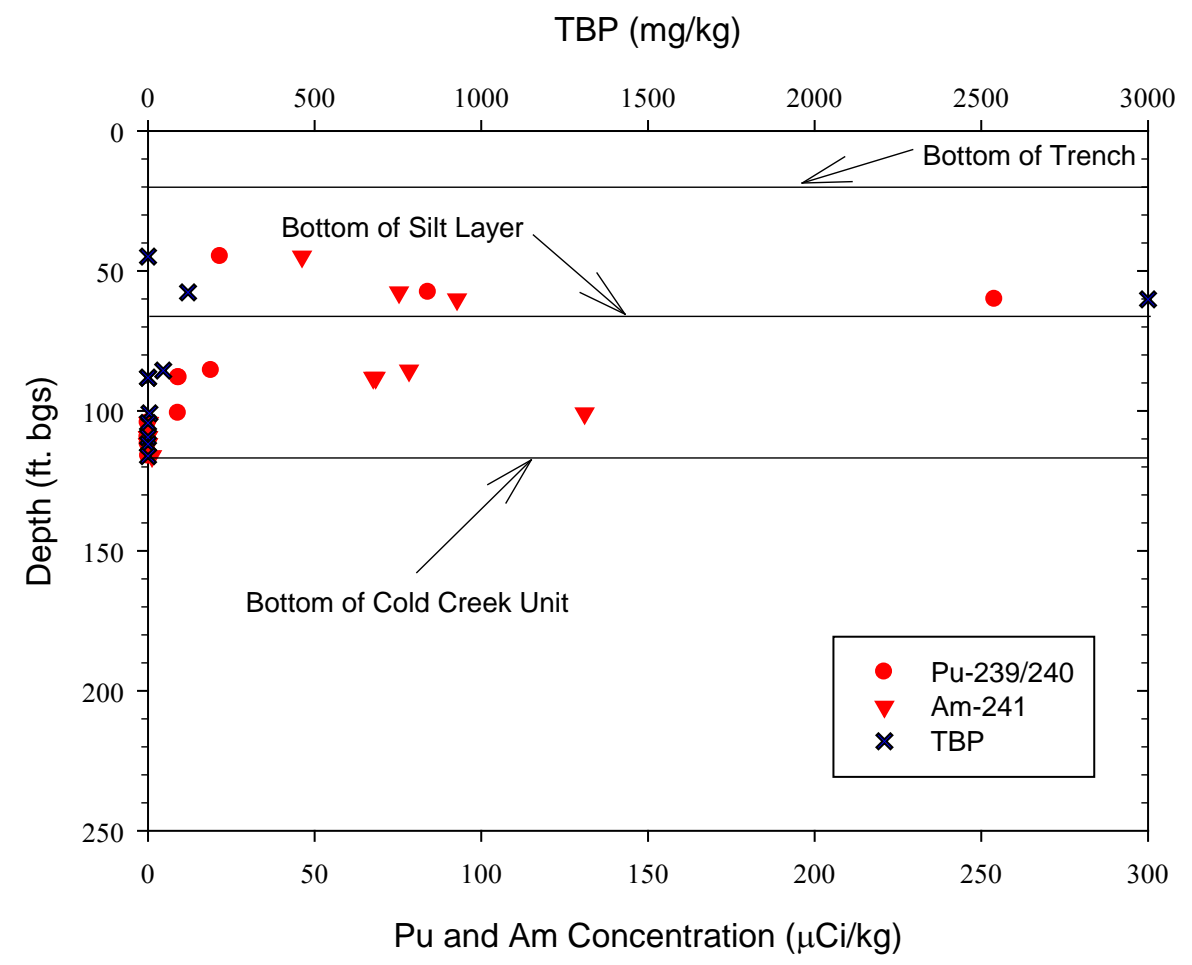

Figure 3.5. Plutonium, Americium, and TBP Concentrations as a Function of Depth Measured in Soil Samples from Well 299-W15-48

\subsubsection{Plutonium Mobility Studies on 216-Z-9 Trench Samples}

As part of a plutonium mobility study (Cantrell et al. 2008), various analyses were conducted on selected sediment samples collected from two wells (299 W15-46 and 299-W15-48) drilled near the 216-Z-9 Trench to elucidate the form and potential for plutonium and americium to become mobilized under present conditions and in future remediation scenarios. Analyses included moisture content, determination of the less than sand size fraction (silt plus clay), carbon analysis, scanning electron microscopy/energy dispersive spectroscopy analysis, microwave-assisted acid digestions for total element analysis, and extraction tests using Hanford Site groundwater as the leachate. Results of the extraction tests were used as input to conduct equilibrium geochemical modeling of the solutions using Geochemist’s Workbench ${ }^{\circledR}$. Geochemical modeling results for plutonium were evaluated in terms of conclusions regarding the solubility and redox reactions of plutonium by Neck et al. (2007a, 2007b).

The highest concentrations of plutonium and americium were associated with sediments of low silt/clay content located above silt/clay rich layers within the sediment profile. It was also found that plutonium and americium were relatively enriched in the silt/clay portion of these samples. Scanning electron microscopy/energy dispersive spectroscopy analysis indicated the plutonium and americium in these sediments does not occur as discrete micron-size particles.

Leaching of these sediment samples with Hanford Site groundwater indicated release of plutonium and americium from the sediments correlates most significantly with the acidity of the water and not the initial concentrations of plutonium and americium in the sediments. Only extracts that were acidic after 
contact with the sediments ( $\mathrm{pH} 4.3$ to 5.4) contained detectable concentrations of extractable plutonium and americium. Water extracts from samples containing high concentrations of TBP indicated that if the TBP degradation products dibutyl phosphate and monobutyl phosphate are available in these sediments, they do not significantly increase the extractability of plutonium or americium.

Geochemical modeling results indicated the americium concentrations in water in contact with these sediments is highly undersaturated with respect to $\mathrm{Am}(\mathrm{OH})_{3}(\mathrm{c})$. It is likely that desorption of americium adsorbed to the sediments during the period of active wastewater disposal is what controls americium concentrations in solutions in contact with these sediments. Sediment extracts that had measureable concentrations of americium occurred only in samples that were fairly acidic ( $\mathrm{pH} 4.3$ to 4.6), indicating that americium will remain effectively sequestered to sediments when $\mathrm{pH}$ conditions approach those of normal Hanford Site groundwater (mildly alkaline, approximately $\mathrm{pH}$ 8).

The geochemical modeling results indicated that plutonium in extracts in contact with acidic sediment is also significantly undersaturated with respect to $\mathrm{PuO}_{2}(\mathrm{am})$ (Cantrell et al. 2008). However, recent reviews of plutonium solubility and redox reactions indicate that considerable uncertainties exist in the data used for these calculations (Neck et al. 2007a, 2007b).

\subsection{PUREX Zone}

Waste sites in the PUREX zone and associated quantities of plutonium, americium, and neptunium nuclides disposed (Ci) (decayed to January 1, 2001) are listed in Table 3.12. Twelve sites in this closure zone received plutonium-239 or americium-241 above $1.0 \mathrm{Ci}$.

\subsubsection{Waste Site 216-A-10}

This site received approximately 3,161 ML of PUREX process condensate/cooling water (Corbin et al. 2005). The estimated inventories of plutonium-239/240 and americium-241 are $69.8 \mathrm{Ci}$ and $75.3 \mathrm{Ci}$, respectively (Table 3.12). The site operated during 1956 and 1961-1988.

Characterization work conducted at this site includes five large-diameter push holes (C4107, C4108, C4110, C4111, C4112) and one borehole (C3247) (DOE/RL 2004). Geophysical logging was performed on the five push holes and the borehole. Sediment samples were collected from the borehole for laboratory analysis. Cesium-137 was detected by geophysical logging in all push holes and the borehole. Europium-154 was also detected by geophysical logging in push holes C4107 and C4111 and borehole C3147.

Analytical results of the sediment samples collected from borehole C3247 indicate maximum concentrations of plutonium-239/240, plutonium-238, americium-241, and neptunium-237 occur within the depth interval of 15.8 to $18.9 \mathrm{~m}$ (52 to $62.5 \mathrm{ft}$ ) bgs at 7,110 pCi/g, $316 \mathrm{pCi} / \mathrm{g}, 1,320 \mathrm{pCi} / \mathrm{g}$, and $0.132 \mathrm{pCi} / \mathrm{g}$, respectively. Below $18.9 \mathrm{~m}$ (62.5 ft), plutonium-239/240 and plutonium-238 concentrations were less than $2.0 \mathrm{pCi} / \mathrm{g}$. Additional americium-241 was detected at $26.5 \mathrm{~m}(87.5 \mathrm{ft})$ at $4.12 \mathrm{pCi} / \mathrm{g}$ but was undetected below this depth. 
Table 3.12. PUREX Zone Waste Sites and Associated Quantities of Plutonium, Americium, and Neptunium Nuclides Disposed (Ci), Decayed to January 1, 2001

\begin{tabular}{|c|c|c|c|c|c|c|}
\hline Waste Site & $\mathrm{Pu}-238$ & $\mathrm{Pu}-239$ & $\mathrm{Pu}-240$ & $\mathrm{Pu}-241$ & Am-241 & Np-237 \\
\hline 216-A-10 & 2.68 & 56.4 & 13.4 & 138 & 75.3 & 2.50 \\
\hline 216-A-11 & $<0.00$ & $<0.00$ & $<0.00$ & $<0.00$ & $<0.00$ & $<0.00$ \\
\hline 216-A-12 & $<0.00$ & $<0.00$ & $<0.00$ & $<0.00$ & $<0.00$ & $<0.00$ \\
\hline 216-A-13 & $<0.00$ & $<0.00$ & $<0.00$ & $<0.00$ & $<0.00$ & $<0.00$ \\
\hline 216-A-14 & $<0.00$ & $<0.00$ & $<0.00$ & $<0.00$ & $<0.00$ & $<0.00$ \\
\hline 216-A-15 & $<0.00$ & $<0.00$ & $<0.00$ & $<0.00$ & $<0.00$ & $<0.00$ \\
\hline 216-A-2 & 0.19 & 7.88 & 1.58 & 6.95 & 0.18 & 0.06 \\
\hline 216-A-21 & 0.22 & 4.61 & 1.13 & 10.1 & 4.61 & 0.02 \\
\hline 216-A-22 & $<0.00$ & $<0.00$ & $<0.00$ & $<0.00$ & $<0.00$ & $<0.00$ \\
\hline 216-A-26 & $<0.00$ & $<0.00$ & $<0.00$ & $<0.00$ & $<0.00$ & $<0.00$ \\
\hline 216-A-26A & $<0.00$ & $<0.00$ & $<0.00$ & $<0.00$ & $<0.00$ & $<0.00$ \\
\hline 216-A-27 & 0.73 & 6.48 & 2.27 & 4.31 & 0.03 & $<0.00$ \\
\hline 216-A-28 & $<0.00$ & $<0.00$ & $<0.00$ & $<0.00$ & $<0.00$ & $<0.00$ \\
\hline 216-A-3 & $<0.00$ & $<0.00$ & $<0.00$ & $<0.00$ & $<0.00$ & $<0.00$ \\
\hline 216-A-30 & 3.44 & 30.7 & 10.7 & 202 & $<0.00$ & $<0.00$ \\
\hline 216-A-31 & $<0.00$ & 0.08 & 0.02 & 0.17 & 0.02 & $<0.00$ \\
\hline 216-A-32 & $<0.00$ & $<0.00$ & $<0.00$ & $<0.00$ & $<0.00$ & $<0.00$ \\
\hline 216-A-35 & $<0.00$ & $<0.00$ & $<0.00$ & $<0.00$ & $<0.00$ & $<0.00$ \\
\hline 216-A-36A & 0.28 & 2.51 & 0.88 & 16.6 & 2.40 & 0.01 \\
\hline 216-A-36B & $<0.00$ & 0.06 & 0.02 & 0.49 & 0.23 & $<0.00$ \\
\hline 216-A-37-1 & 0.01 & 0.12 & 0.04 & 0.94 & 0.12 & $<0.00$ \\
\hline 216-A-37-2 & 0.01 & 0.14 & 0.04 & 1.16 & 0.04 & $<0.00$ \\
\hline 216-A-4 & 0.12 & 1.08 & 0.38 & 7.20 & 0.01 & $<0.00$ \\
\hline $216-A-40$ & $<0.00$ & $<0.00$ & $<0.00$ & $<0.00$ & $<0.00$ & $<0.00$ \\
\hline 216-A-41 & $<0.00$ & $<0.00$ & $<0.00$ & $<0.00$ & $<0.00$ & $<0.00$ \\
\hline 216-A-45 & 0.09 & 0.92 & 0.26 & 7.62 & 1.25 & 0.04 \\
\hline 216-A-5 & 0.81 & 32.6 & 6.55 & 28.8 & 43.0 & 1.31 \\
\hline 216-A-6 & 0.11 & 2.95 & 0.66 & 5.08 & 2.94 & 0.09 \\
\hline 216-A-9 & 20.7 & 183 & 64.3 & 1,210 & 0.10 & $<0.00$ \\
\hline UPR-200-E-117 & $<0.00$ & $<0.00$ & $<0.00$ & $<0.00$ & $<0.00$ & $<0.00$ \\
\hline UPR-200-E-39 & $<0.00$ & $<0.00$ & $<0.00$ & 0.02 & $<0.00$ & $<0.00$ \\
\hline
\end{tabular}

\subsubsection{Waste Site 216-A-2}

This site received 230,000 L (60,766 gal) of PUREX organic waste (Corbin et al. 2005). The estimated inventories of plutonium-239/240 and americium-241 are $9.46 \mathrm{Ci}$ and $0.18 \mathrm{Ci}$, respectively (Table 3.12). The site operated during 1956-1960. 


\subsubsection{Waste Site 216-A-21}

This site received 77.9 ML of PUREX caustic scrubber waste (Corbin et al. 2005). The estimated inventories of plutonium-239/240 and americium-241 are 5.74 Ci and 4.61 Ci, respectively (Table 3.12). The site operated during 1957-1965.

\subsubsection{Waste Site 216-A-27}

This site received approximately 23.2 ML of PUREX stack drainage and laboratory cell waste. The majority of the waste is assumed to be PUREX stack drainage, with a small fraction of laboratory cell waste assumed to resemble PL1, including a solids contribution represented by an asymmetric triangular distribution. The estimated inventories of plutonium-239/240 and americium-241 are $8.75 \mathrm{Ci}$ and $0.03 \mathrm{Ci}$, respectively (Table 3.12). This site operated during 1965-1970.

\subsubsection{Waste Site 216-A-30}

This site received approximately 7,635 ML of PUREX condensate and miscellaneous drainage (Corbin et al. 2005). The waste streams selected to represent the process history of this site are decontamination waste, PUREX chemical sewer, PUREX steam condensate, and PUREX stack drainage. The estimated inventories of plutonium-239/240 and americium-241 are $41.4 \mathrm{Ci}$ and $<0.00 \mathrm{Ci}$, respectively (Table 3.12). The site operated during 1961-1991.

Characterization of the 216-A-30 Crib is limited to geophysical logging (DOE/RL 2007c). Scintillation logging was conducted on Wells 299-E16-2, 299-E25-11, and 299-E25-12 (Fecht et al. 1977). All three of these wells are located along the southern edge of the crib. Low-level radioactive contaminants were detected in Wells 299-E25-11 and 299-E25-12 in 1963. In 1976, the scintillation probe profiles showed minor activity in all three wells. Spectral gamma logging was performed in Wells 299-E25-190, 299-E25-190, and 299-E25-190 in 2006 (Stoller 2006). These three wells are located along the northern edge of the crib. All three wells had minor amounts of cesium-137, mostly above $6 \mathrm{~m}(20 \mathrm{ft})$ bgs. Total gamma anomalies occurred between 4.6 and $13 \mathrm{~m}$ (15 and $43 \mathrm{ft})$ bgs that were not correlated with the cesium-137 concentrations. Analysis of the logging results indicated the possibility that the gamma anomalies were due to strontium-90 at concentrations in excess of $500 \mathrm{pCi} / \mathrm{g}$.

In 2008, an additional borehole was drilled within the 216-A-30 Crib to further characterize the site (Buswell and Sexton 2008). Geophysical logging was performed, and sediment samples were collected for chemical characterization. No results for plutonium or americium were reported as part of the chemical characterization (Lindberg 2008).

\subsubsection{Waste Site 216-A-36A}

This site received approximately 1 ML of PUREX ammonia scrubber waste (Corbin et al. 2005). The estimated inventories of plutonium-239/240 and americium-241 are 3.39 Ci and 2.40 Ci, respectively (Table 3.12). The site operated during 1965 and 1966. 


\subsubsection{Waste Site 216-A-4}

This site received approximately 6.2 ML of uranyl nitrate hexhydrate (UNH) process condensate and PUREX laboratory waste (Corbin et al. 2005). The estimated inventories of plutonium-239/240 and americium-241 are $1.46 \mathrm{Ci}$ and $0.01 \mathrm{Ci}$, respectively (Table 3.12). The site operated during 1955-1958.

\subsubsection{Waste Site 216-A-45}

This site received 103 ML of PUREX process condensates, steam condensate, and dilute UNH condensate (Corbin et al. 2005). The estimated inventories of plutonium-239/240 and americium-241 are $1.18 \mathrm{Ci}$ and $1.25 \mathrm{Ci}$, respectively (Table 3.12). The site operated during 1987-1989.

\subsubsection{Waste Site 216-A-45}

This site received 103 ML of PUREX process condensates, steam condensate, and dilute UNH condensate. The estimated inventories of plutonium-239/240 and americium-241 are $1.18 \mathrm{Ci}$ and $1.25 \mathrm{Ci}$, respectively (Table 3.12). The site operated during 1987-1989.

\subsubsection{Waste Site 216-A-5}

This site received approximately 1,633 ML of PUREX process condensate. The site operated during 1955-1961 and 1966 (Corbin et al. 2005). The estimated inventories of plutonium-239/240 and americium-241 are 39.2 $\mathrm{Ci}$ and $43.0 \mathrm{Ci}$, respectively (Table 3.12).

Plans for characterization of the 216-A-5 Crib are described in Williams (2008). The projected characterization activities include one deep vadose borehole drilled to approximately $99.1 \mathrm{~m}$ (325 ft) bgs using conventional drilling techniques and one direct-push technique borehole. At the time of the writing of this report, the characterization work had been completed but a report documenting the results had not been completed; however, analysis data for the samples collected from borehole C6552 are available in HEIS. These results indicate that maximum concentrations for plutonium-239/240, americium-241, and neptunium-237 are $936 \mathrm{pCi} / \mathrm{g}, 422 \mathrm{pCi} / \mathrm{g}$, and $0.393 \mathrm{pCi} / \mathrm{g}$, respectively, and these maxima occur within the depth interval of 10.6 to $11.4 \mathrm{~m}$ (34.7 to $37.3 \mathrm{ft}$ ) bgs.

\subsubsection{Waste Site 216-A-6}

This site received approximately 3,360 ML of PUREX condensate and miscellaneous drainage (Corbin et al. 2005). The waste streams selected to represent the process history of this site are decontamination waste, PUREX chemical sewer, PUREX steam condensate, spent nitric acid, and PUREX stack drainage. The estimated inventories of plutonium-239/240 and americium-241 are 3.61 Ci and $2.94 \mathrm{Ci}$, respectively (Table 3.12). The site operated during 1955-1961 and 1966-1970. 


\subsubsection{Waste Site 216-A-9}

This site received 980 ML of PUREX chemical sewer, cooling water, tank farm condensate, and N Reactor decontamination waste (Corbin et al. 2005). The estimated inventories of plutonium-239/240 and americium-241 are $247 \mathrm{Ci}$ and $0.10 \mathrm{Ci}$, respectively (Table 3.12). The site operated during 1956-1958 and 1966-1967.

\subsection{REDOX Zone}

Waste sites in the REDOX zone and associated quantities of plutonium, americium, and neptunium nuclides disposed (Ci) (decayed to January 1, 2001) are listed in Table 3.13. Four sites in this closure zone received plutonium-239 or americium-241 above $1.0 \mathrm{Ci}$.

Table 3.13. REDOX Zone Waste Sites and Associated Quantities of Plutonium, Americium, and Neptunium Nuclides Disposed (Ci), Decayed to January 1, 2001

\begin{tabular}{lcccccr}
\hline \multicolumn{1}{c}{ Waste Site } & Pu-238 & Pu-239 & Pu-240 & Pu-241 & Am-241 & Np-237 \\
\hline 200-W-22 & $<0.00$ & $<0.00$ & $<0.00$ & $<0.00$ & $<0.00$ & $<0.00$ \\
$216-S-1 \& 2$ & 1.38 & 72.8 & 14.1 & 49.2 & 25.5 & 0.51 \\
$216-S-12$ & $<0.00$ & 0.11 & 0.02 & 0.07 & 0.04 & $<0.00$ \\
$216-S-13$ & 0.04 & 0.70 & 0.16 & 1.07 & 0.94 & 0.01 \\
$216-S-20$ & 0.73 & 18.4 & 4.17 & 33.6 & 56.2 & 0.12 \\
$216-S-22$ & $<0.00$ & $<0.00$ & $<0.00$ & $<0.00$ & $<0.00$ & $<0.00$ \\
$216-S-23$ & $<0.00$ & $<0.00$ & $<0.00$ & $<0.00$ & $<0.00$ & $<0.00$ \\
216-S-7 & 2.31 & 69.4 & 14.3 & 68.9 & 16.8 & 0.49 \\
$216-S-8$ & $<0.00$ & $<0.00$ & $<0.00$ & $<0.00$ & $<0.00$ & $<0.00$ \\
$216-S-9$ & 0.19 & 2.90 & 0.68 & 5.14 & 0.03 & 0.02 \\
UPR-200-W-32 & $<0.00$ & $<0.00$ & $<0.00$ & $<0.00$ & $<0.00$ & $<0.00$ \\
UPR-200-W-61 & $<0.00$ & $<0.00$ & $<0.00$ & $<0.00$ & $<0.00$ & $<0.00$ \\
UPR-200-W-82 & $<0.00$ & $<0.00$ & $<0.00$ & $<0.00$ & $<0.00$ & $<0.00$ \\
UPR-200-W-87 & $<0.00$ & $<0.00$ & $<0.00$ & $<0.00$ & $<0.00$ & $<0.00$ \\
UPR-200-W-96 & $<0.00$ & $<0.00$ & $<0.00$ & $<0.00$ & $<0.00$ & $<0.00$ \\
\hline
\end{tabular}

\subsubsection{Waste Site 216-S-1\&2}

This site received 160 ML of REDOX D-1 cell drainage and D-2 process condensate. Disposal volumes were presented; however, no contributing volumes are broken out (Corbin et al. 2005). The estimated inventories of plutonium-239/240 and americium-241 are $86.9 \mathrm{Ci}$ and $25.5 \mathrm{Ci}$, respectively (Table 3.13). The site operated during 1952-1956.

The 216-S-1\&2 Cribs are located approximately $430 \mathrm{~m}$ (1,410 ft) northwest of the REDOX building in the 200 West Area. The crib was constructed in 1950 and 1951. The crib consists of two openbottomed, square, wooden crib boxes, $3.7 \mathrm{~m}$ (12 ft) on each side and $2.9 \mathrm{~m}$ (9.5 ft) high, located approximately $6 \mathrm{~m}$ (20 ft) below grade. Additional design and construction details of the facility are provided in Van Luik and Smith (1982). The 216-S-1\&2 Crib received waste from the cell drainage 
collection tank, D-1, and the condensate receiver tank, D-2, located in the REDOX building. Waste was discharged to the crib in batches of about 19,000 L (5,020 gal) at an average rate of 10 batches per day (Haney and Linderoth 1959). The crib received approximately $1.6 \times 10^{8}$ liter of waste containing approximately $5.5 \times 10^{5} \mathrm{Ci}$ of mixed fission products from 1952 to 1956 (Hanson et al. 1973). The average $\mathrm{pH}$ of the D-1 and D-2 wastes was 2.1 (Rhodes 1956). Included in the waste disposed to the crib was $1.2 \mathrm{~kg}$ of plutonium.

A characterization study of the site was conducted by Van Luik and Smith (1982). Borehole scintillation and gamma spectroscopy profiles of monitoring wells in and around the crib were obtained during this study. Results of this study indicated that migration of cesium-137 was confined to a $10-\mathrm{m}$ (33-ft) zone beneath the crib bottom. Because no sediment samples were analyzed for plutonium, no definite conclusions can be drawn with respect to its behavior at the site; however, it is assumed that plutonium migration was limited in a fashion similar to that of cesium-137.

Plans for additional characterization of the 216-S-1\&2 Cribs are described in Williams (2008). The projected characterization activities include one deep vadose borehole drilled to approximately $70.1 \mathrm{~m}$ (230 ft) bgs using conventional drilling techniques and two direct-push technique boreholes.

\subsubsection{Waste Site 216-S-20}

This site received $135 \mathrm{ML}$ of REDOX and 300 Area laboratory waste. Some of the higher-activity 300 Area waste is represented using PL1 waste as a proxy (Corbin et al. 2005). The estimated inventories of plutonium-239/240 and americium-241 are 22.6 Ci and 56.2 Ci, respectively (Table 3.13). The site operated during 1952-1969 and 1972-1973.

Little historical characterization information is available to evaluate the nature and extent of contamination at the 216-S-20 Crib (DOE/RL 2002b). Available data include scintillation and gross gamma log profiles from borehole 299-W22-20 and spectral gamma data from borehole 299-W22-74. Borehole 299-W22-20 is $35 \mathrm{~m}$ (115 ft) downgradient of the 216-S-20 Crib and was logged with a scintillation probe in 1963, 1968, and 1976 (Fecht et al. 1977). Near-background levels of radioactivity were detected over most of the log interval. At a depth of about 48 to $50 \mathrm{~m}$ (157 to $164 \mathrm{ft}$ ) bgs, the radiation intensity was elevated in 1963. This radiation intensity was due to releases of total beta that occurred between 1961 and 1963 (Fecht et al. 1977). A gamma log run in 1994 showed near-background levels of radioactivity in the borehole. Spectral gamma logging of borehole 299-W22-74 detected only very low levels of cobalt-60 (2 pCi/g or less) at a depth interval of about 8 to $12 \mathrm{~m}$ (26 to $40 \mathrm{ft}$ ) bgs.

More recent characterization of the 216-S-20 Crib includes a borehole (C4176) drilled in 2004 (DOE/RL 2006). Laboratory analyses were conducted on the sediment samples collected from the borehole, and the borehole was logged using geophysical methods. Spectral gamma logging detected cesium-137, cobalt-60, and uranium-238 (based on the protactinium-234m gamma line at 1,001 keV). Laboratory analyses for transuranic radionuclides in the sediments indicate a maximum plutonium239/240 concentration of 78 pCi/g detected between 9.9 and $10.7 \mathrm{~m}$ (32.5 and $35 \mathrm{ft}$ ) bgs. The maximum plutonium-238 concentration was detected between 9.9 and $10.7 \mathrm{~m}$ (32.5 and $35 \mathrm{ft}$ ) bgs at $2.6 \mathrm{pCi} / \mathrm{g}$. The maximum americium-241 concentration was detected between 9.0 and $9.8 \mathrm{~m}$ (29.5 and $32 \mathrm{ft}$ ) bgs at $5,800 \mathrm{pCi} / \mathrm{g}$. The maximum neptunium-237 concentration was detected between 9.9 and $10.7 \mathrm{~m}$ ( 29.5 and $35 \mathrm{ft}$ ) at $0.084 \mathrm{pCi} / \mathrm{g}$. For each of the transuranic radionuclides discussed above, concentrations decrease dramatically with depth below the maximum. 


\subsubsection{Waste Site 216-S-7}

This site received $390 \mathrm{ML}$ of REDOX D-1 cell drainage and D-2 process condensate. Yearly disposal volumes are presented; however, no contributing volumes are broken out (Corbin et al. 2005). The estimated inventories of plutonium-239/240 and americium-241 are $83.7 \mathrm{Ci}$ and $16.8 \mathrm{Ci}$, respectively (Table 3.13). The site operated during 1956-1965.

In late 2004 and early 2005, a characterization borehole (C4557) was drilled in the center of the 216-S-7 Crib (Fluor Hanford 2005). Sediment samples were collected for laboratory analysis of chemical constituents and radionuclides. Spectral gamma-ray logging was also conducted on the borehole. Cesium-137 was the only manmade radionuclide found in the borehole between ground surface and $39.0 \mathrm{~m}$ (128 ft) bgs. A maximum concentration of approximately 2,000,000 pCi/g was measured at $7.6 \mathrm{~m}$ ( $25 \mathrm{ft}$ ) bgs. The highest concentration zone occurred between 4.6 and $10.7 \mathrm{~m} \mathrm{(15} \mathrm{and} 35 \mathrm{ft}$ ) bgs. At the time of the writing of this report, the characterization work had been completed but a report documenting the results had not been published; however, analysis data for the samples collected from borehole C4557 are available in HEIS. These results indicate that maximum concentrations for plutonium-239/240 and americium-241 are 11,000 pCi/g and 1,900 pCi/g, both of which were found at a depth of 7.32 to $8.08 \mathrm{~m}$ (24.0 to $26.5 \mathrm{ft}$ ) bgs.

\subsubsection{Waste Site 216-S-9}

This site received 49.5 ML of REDOX D-1 cell drainage and D-2 process condensate (Corbin et al. 2005). The estimated inventories of plutonium-239/240 and americium-241 are $2.58 \mathrm{Ci}$ and $0.03 \mathrm{Ci}$, respectively (Table 3.13). The site operated during 1965-1969.

\subsection{S-U Farm Zone}

Waste sites in the S-U Farm zone and associated quantities of plutonium, americium, and neptunium nuclides disposed (Ci) (decayed to January 1, 2001) are listed in Table 3.14. Only one site in this closure zone received plutonium-239 or americium-241 above 1.0 Ci (241-SX-115).

Characterization efforts conducted within the S-U Farm zone include a borehole (41-09-39) installed adjacent to Tank SX-109 (Serne et al. 2002). Characterization results indicate very minor plutonium and americium contaminated associated with sediments from this borehole. Only one sample contained detectable plutonium and americium. The sample was from a depth of 17.1 to $17.4 \mathrm{~m}$ (56 to $57 \mathrm{ft}$ ) bgs and contained plutonium-239 at a concentration of $3.96 \mathrm{pCi} / \mathrm{g}$ and americium at a concentration of $0.088 \mathrm{pCi} / \mathrm{g}$.

\subsubsection{Waste Site 241-SX-115}

This tank farm leak event occurred in 1965. Principal wastes were CWR2 [REDOX cladding waste, aluminum clad fuel (1961-1966)], R1 [REDOX high-level waste (1952-1958)], and R2 [REDOX highlevel waste (1959-1966)] with zero solids (Corbin et al. 2005). The estimated inventories of plutonium239/240 and americium-241 are 1.17 Ci and 1.26 Ci, respectively (Table 3.14). 
Table 3.14. S-U Farm Zone Waste Sites and Associated Quantities of Plutonium, Americium, and Neptunium Nuclides Disposed (Ci), Decayed to January 1, 2001

\begin{tabular}{lrrrrrr}
\hline \multicolumn{1}{c}{ Waste Site } & Pu-238 & Pu-239 & Pu-240 & Pu-241 & Am-241 & Np-237 \\
\hline $216-S-15$ & $<0.00$ & $<0.00$ & $<0.00$ & $<0.00$ & $<0.00$ & $<0.00$ \\
$216-S-3$ & $<0.00$ & $<0.00$ & $<0.00$ & $<0.00$ & $<0.00$ & $<0.00$ \\
$216-U-13$ & $<0.00$ & $<0.00$ & $<0.00$ & $<0.00$ & $<0.00$ & $<0.00$ \\
$216-U-3$ & $<0.00$ & $<0.00$ & $<0.00$ & $<0.00$ & $<0.00$ & $<0.00$ \\
$241-S-104$ & 0.01 & 0.46 & 0.10 & 0.65 & 0.61 & $<0.00$ \\
241-SX-107 & 0.01 & 0.29 & 0.06 & 0.35 & 0.38 & 0.02 \\
241-SX-108 & 0.03 & 0.67 & 0.14 & 0.81 & 0.89 & 0.06 \\
241-SX-109 & $<0.00$ & 0.04 & 0.01 & 0.05 & 0.05 & $<0.00$ \\
241-SX-111 & $<0.00$ & 0.01 & $<0.00$ & 0.02 & 0.02 & $<0.00$ \\
241-SX-113 & 0.01 & 0.29 & 0.06 & 0.19 & 0.38 & 0.01 \\
241-SX-115 & 0.03 & 0.96 & 0.21 & 1.29 & 1.26 & 0.02 \\
241-U-104 & 0.01 & 0.91 & 0.12 & 0.26 & 0.83 & 0.01 \\
241-U-110 & $<0.00$ & 0.02 & $<0.00$ & 0.03 & 0.03 & $<0.00$ \\
241-U-112 & $<0.00$ & 0.14 & 0.03 & 0.85 & 0.16 & $<0.00$ \\
UPR-200-W-20 & $<0.00$ & $<0.00$ & $<0.00$ & $<0.00$ & $<0.00$ & $<0.00$ \\
241-SX-104 & $<0.00$ & 0.11 & 0.02 & 0.18 & 0.15 & 0.01 \\
241-SX-110 & $<0.00$ & 0.01 & $<0.00$ & 0.03 & 0.03 & $<0.00$ \\
241-U-101 & $<0.00$ & 0.09 & 0.02 & 0.06 & 0.12 & $<0.00$ \\
\hline
\end{tabular}

\subsection{Solid Waste Zone}

Liquid waste sites in the Solid Waste zone and associated quantities of plutonium, americium, and neptunium nuclides disposed (Ci) (decayed to January 1, 2001) are listed in Table 3.15. Only one site in this closure zone received plutonium-239 or americium-241 above 1.0 Ci (216-B-9).

Table 3.15. Liquid Waste Sites within the Solid Waste Zone and Associated Quantities of Plutonium, Americium, and Neptunium Nuclides Disposed (Ci), Decayed to January 1, 2001

\begin{tabular}{lrrrrrl}
\hline \multicolumn{1}{c}{ Waste Site } & Pu-238 & Pu-239 & Pu-240 & Pu-241 & Am-241 & Np-237 \\
\hline 216-B-63 & $<0.00$ & 0.02 & $<0.00$ & 0.02 & 0.04 & $<0.00$ \\
216-B-9 & 0.04 & 8.08 & 0.71 & 1.14 & 0.13 & $<0.00$ \\
UPR-200-E-78 & $<0.00$ & $<0.00$ & $<0.00$ & $<0.00$ & 0.04 & $<0.00$ \\
\hline
\end{tabular}

\subsubsection{Waste Site 216-B-9}

This site received 36 ML of 5-6 liquid waste (Corbin et al. 2005). The estimated inventories of plutonium-239/240 and americium-241 are $8.79 \mathrm{Ci}$ and $0.13 \mathrm{Ci}$, respectively (Table 3.15). This site operated during 1948-1951. 


\subsection{T Farm Zone}

Waste sites in the T Farm zone and associated quantities of plutonium, americium, and neptunium nuclides disposed (Ci) (decayed to January 1, 2001) are listed in Table 3.16. Fifteen sites in this closure zone received plutonium-239 or americium-241 above $1.0 \mathrm{Ci}$.

\subsubsection{Waste Site 216-T-18}

This site received approximately $1 \mathrm{ML}$ of $1 \mathrm{C}$ waste (Corbin et al. 2005). The estimated inventories of plutonium-239/240 and americium-241 are 3.46 Ci and 0.09 Ci, respectively (Table 3.16). This site operated during 1953.

\subsubsection{Waste Site 216-T-19}

This site received $455 \mathrm{ML}$ of 5-6 waste, $2 \mathrm{C}$ waste $\left(\mathrm{BiPO}_{4}\right.$ second cycle decontamination waste), and 242-T Evaporator condensate (Corbin et al. 2005). The estimated inventories of plutonium-239/240 and americium-241 are $9.41 \mathrm{Ci}$ and $0.29 \mathrm{Ci}$, respectively (Table 3.16). This site operated during 1951-1956 and 1965-1976.

\subsubsection{Waste Site 216-T-25}

This site received 2.987 ML of 1C waste (Corbin et al. 2005). The estimated inventories of plutonium-239/240 and americium-241 are $1.38 \mathrm{Ci}$ and $1.55 \mathrm{Ci}$, respectively (Table 3.16). This site operated during 1954.

\subsubsection{Waste Site 216-T-26}

This site received 11 ML of ferrocyanide waste (Corbin et al. 2005). The estimated inventories of plutonium-239/240 and americium-241 are 39.4 Ci and 1.09 Ci, respectively (Table 3.16). This site operated during 1955-1956. Characterization of the nature and vertical extent of contamination beneath the 216-T-26 Crib consists of soil samples and geophysical logging data collected from borehole C3102 (DOE/RL 2002b). The only radionuclides detected were cesium-137, cobalt-60, and europium-154.

\subsubsection{Waste Site 216-T-27}

The WIDS (DOE/RL 2002a) documents that this site received approximately 7 ML of decontamination waste and 300 Area laboratory waste. The 300 Area laboratory waste is represented as 222-S Laboratory waste with a small contribution of PL1. There are discrepancies in the source documents regarding the volume disposed to this site; however, they appear to be typographical errors involving the decimal point (Corbin et al. 2005). The estimated inventories of plutonium-239/240 and americium-241 are $1.97 \mathrm{Ci}$ and $2.30 \mathrm{Ci}$, respectively (Table 3.16). This site operated during 1965. 
Table 3.16. T Farm Zone Waste Sites and Associated Quantities of Plutonium, Americium, and Neptunium Nuclides Disposed (Ci), Decayed to January 1, 2001

\begin{tabular}{|c|c|c|c|c|c|c|}
\hline Waste Site & $\mathrm{Pu}-238$ & $\mathrm{Pu}-239$ & $\mathrm{Pu}-240$ & $\mathrm{Pu}-241$ & Am-241 & Np-237 \\
\hline 216-T-12 & $<0.00$ & $<0.00$ & $<0.00$ & $<0.00$ & $<0.00$ & $<0.00$ \\
\hline 216-T-14 & $<0.00$ & 0.41 & 0.06 & 0.13 & 0.52 & $<0.00$ \\
\hline 216-T-15 & $<0.00$ & 0.42 & 0.06 & 0.14 & 0.54 & $<0.00$ \\
\hline 216-T-16 & $<0.00$ & 0.41 & 0.06 & 0.13 & 0.53 & $<0.00$ \\
\hline 216-T-17 & $<0.00$ & 0.32 & 0.04 & 0.10 & 0.41 & $<0.00$ \\
\hline 216-T-18 & 0.01 & 3.24 & 0.22 & 0.28 & 0.09 & $<0.00$ \\
\hline 216-T-19 & 0.08 & 8.35 & 1.06 & 2.39 & 0.29 & $<0.00$ \\
\hline 216-T-20 & $<0.00$ & $<0.00$ & $<0.00$ & $<0.00$ & $<0.00$ & $<0.00$ \\
\hline 216-T-21 & $<0.00$ & 0.19 & 0.03 & 0.06 & 0.24 & $<0.00$ \\
\hline 216-T-22 & 0.01 & 0.62 & 0.09 & 0.02 & 0.80 & 0.01 \\
\hline 216-T-23 & 0.01 & 0.61 & 0.09 & 0.20 & 0.77 & 0.01 \\
\hline 216-T-24 & 0.01 & 0.62 & 0.09 & 0.20 & 0.80 & 0.01 \\
\hline 216-T-25 & 0.01 & 1.21 & 0.17 & 0.40 & 1.55 & 0.01 \\
\hline 216-T-26 & 0.13 & 36.9 & 2.50 & 3.22 & 1.09 & 0.04 \\
\hline 216-T-27 & 0.13 & 1.51 & 0.46 & 7.18 & 2.30 & $<0.00$ \\
\hline 216-T-28 & 3.90 & 36.8 & 12.4 & 225 & 15.5 & 0.02 \\
\hline 216-T-29 & $<0.00$ & $<0.00$ & $<0.00$ & $<0.00$ & $<0.00$ & $<0.00$ \\
\hline 216-T-3 & 0.06 & 15.6 & 1.12 & 1.08 & 0.07 & $<0.00$ \\
\hline 216-T-32 & 0.04 & 5.42 & 0.55 & 1.01 & 0.84 & 0.02 \\
\hline 216-T-34 & 0.59 & 5.18 & 1.80 & 34.0 & 1.81 & $<0.00$ \\
\hline 216-T-35 & 0.10 & 0.88 & 0.31 & 5.83 & 3.14 & $<0.00$ \\
\hline 216-T-36 & 1.92 & 16.9 & 5.91 & 111 & $<0.00$ & $<0.00$ \\
\hline 216-T-5 & 0.15 & 16.5 & 2.09 & 4.59 & 0.44 & 0.01 \\
\hline 216-T-6 & 0.05 & 15.1 & 1.02 & 0.99 & 0.07 & $<0.00$ \\
\hline 216-T-7 & 1.77 & 236 & 26.4 & 53.1 & 6.57 & 0.10 \\
\hline 241-T-101 & $<0.00$ & 0.16 & 0.03 & 0.16 & 0.20 & $<0.00$ \\
\hline UPR-200-W-131 & $<0.00$ & $<0.00$ & $<0.00$ & $<0.00$ & $<0.00$ & $<0.00$ \\
\hline UPR-200-W-135 & $<0.00$ & 0.02 & $<0.00$ & 0.01 & 0.02 & $<0.00$ \\
\hline 241-T-103 & $<0.00$ & 0.05 & 0.01 & 0.10 & 0.18 & $<0.00$ \\
\hline 241-T-106 & 0.09 & 1.97 & 0.46 & 4.01 & 7.55 & 0.12 \\
\hline 241-TX-107 & 0.01 & 0.15 & 0.03 & 0.27 & 0.20 & 0.01 \\
\hline 241-TY-101 & $<0.00$ & 0.02 & $<0.00$ & 0.03 & 0.02 & $<0.00$ \\
\hline 241-TY-103 & $<0.00$ & 0.06 & 0.01 & 0.10 & 0.08 & 0.01 \\
\hline 241-TY-104 & $<0.00$ & 0.02 & $<0.00$ & $<0.00$ & 0.01 & $<0.00$ \\
\hline 241-TY-105 & $<0.00$ & 0.39 & 0.04 & 0.08 & 0.22 & $<0.00$ \\
\hline 241-TY-106 & $<0.00$ & 0.22 & 0.02 & 0.05 & 0.12 & $<0.00$ \\
\hline UPR-200-W-28 & $<0.00$ & 0.01 & $<0.00$ & $<0.00$ & $<0.00$ & $<0.00$ \\
\hline UPR-200-W-29 & $<0.00$ & $<0.00$ & $<0.00$ & $<0.00$ & $<0.00$ & $<0.00$ \\
\hline UPR-200-W-97 & $<0.00$ & 0.01 & $<0.00$ & $<0.00$ & $<0.00$ & $<0.00$ \\
\hline 241-T-108 & $<0.00$ & 0.02 & $<0.00$ & $<0.00$ & 0.01 & $<0.00$ \\
\hline 241-T-109 & $<0.00$ & 0.02 & $<0.00$ & 0.03 & 0.04 & $<0.00$ \\
\hline 241-T-111 & $<0.00$ & 0.01 & $<0.00$ & $<0.00$ & $<0.00$ & $<0.00$ \\
\hline
\end{tabular}




\subsubsection{Waste Site 216-T-28}

This site received $42 \mathrm{ML}$ of decontamination waste and 300 Area laboratory waste. The 300 Area laboratory waste is represented as 222-S Laboratory waste with a small contribution of PL1 [PUREX non-boiling waste (1968-1972)] (Corbin et al. 2005). The estimated inventories of plutonium-239/240 and americium-241 are $49.2 \mathrm{Ci}$ and $15.5 \mathrm{Ci}$, respectively (Table 3.16). This site operated during 1960-1966.

Early characterization of the nature and extent of contamination in the vicinity of the 216-T-28 Crib was conducted through scintillation probe profiles and spectral gamma logging (DOE/RL 2002b). Scintillation profiles have been collected from four boreholes between 1959 and 1976 (Fecht et al. 1977). Boreholes 299-W14-2 and 299-W14-3 are located within the waste site boundary, while boreholes 299-W14-1 and 299-W14-4 are located adjacent to the site. Analysis of these data indicate that radioactive contamination is present from near the surface to the water table, significant lateral spreading to the southeast (toward borehole 299-W14-1) appears to be likely, and no measureable migration of radionuclides has occurred after cessation of waste disposal to the site. Spectral gamma logging was performed on these same boreholes between 1992 and 1995 (DOE/RL 2002b). The distribution of contamination determined with the scintillation probe was confirmed with the spectral gamma logging, and specific radionuclides were detected. The radionuclides detected were cesium-137, cobalt-60, europium-152, and europium-154.

More recent characterization of the 216-T-28 Crib includes a borehole (C4175) drilled in 2004 (DOE/RL 2006). Laboratory analyses were conducted on the sediment samples collected from the borehole, and the borehole was geophysically logged.

Spectral gamma logging detected cesium-137, cobalt-60, and europium-154. Laboratory analyses for transuranic radionuclides in the sediments indicate a maximum plutonium-239/240 concentration of 1,110 pCi/g between 5.3 and $6 \mathrm{~m}$ (17.5 and $20 \mathrm{ft})$. The maximum plutonium-238 concentration was detected between 5.3 and $6 \mathrm{~m}$ (17.5 and $20 \mathrm{ft})$ at $84.5 \mathrm{pCi} / \mathrm{g}$. The maximum americium-241 concentration was detected between 5.3 and $6 \mathrm{~m}(17.5$ and $20 \mathrm{ft})$ at $802 \mathrm{pCi} / \mathrm{g}$. For each of the three transuranic radionuclides discussed above, concentrations decrease dramatically with depth below the maximum.

\subsubsection{Waste Site 216-T-3}

This site received 11.3 ML of 224 and 5-6 waste disposal from 1945-1946 (Corbin et al. 2005). The estimated inventories of plutonium-239/240 and americium-241 are $16.7 \mathrm{Ci}$ and $0.07 \mathrm{Ci}$, respectively (Table 3.16).

\subsubsection{Waste Site 216-T-32}

This site received 29 ML of 224 waste from 1946-1952 (Corbin et al. 2005). The estimated inventories of plutonium-239/240 and americium-241 are 5.97 Ci and $0.84 \mathrm{Ci}$, respectively (Table 3.16). 


\subsubsection{Waste Site 216-T-34}

This site received 17.3 ML of decontamination waste and 222-S Laboratory waste (Corbin et al. 2005). The estimated inventories of plutonium-239/240 and americium-241 are $6.98 \mathrm{Ci}$ and $1.81 \mathrm{Ci}$, respectively (Table 3.16). This site operated during 1966-1967.

\subsubsection{Waste Site 216-T-35}

This site received 5.7 ML of 222-S Laboratory waste (Corbin et al. 2005). The estimated inventories of plutonium-239/240 and americium-241 are $1.19 \mathrm{Ci}$ and 3.14 Ci, respectively (Table 3.16). This site operated during 1967-1968.

\subsubsection{Waste Site 216-T-36}

This site received 509,000 L (134,742 gal) of decontamination waste (Corbin et al. 2005). The estimated inventories of plutonium-239/240 and americium-241 are 22.8 Ci and $<0.00 \mathrm{Ci}$, respectively (Table 3.16). This site operated during 1967-1969.

\subsubsection{Waste Site 216-T-5}

This site received 3.15 ML of 2C waste (Corbin et al. 2005). The estimated inventories of plutonium239/240 and americium-241 are 18.6 Ci and 0.44 Ci, respectively (Table 3.16). This site operated during 1955.

\subsubsection{Waste Site 216-T-6}

This site received 45 ML of 224 and 5-6 waste from 1946-1947 (Corbin et al. 2005). The estimated inventories of plutonium-239/240 and americium-241 are $16.1 \mathrm{Ci}$ and $0.07 \mathrm{Ci}$, respectively (Table 3.16).

\subsubsection{Waste Site 216-T-7}

This site received approximately 107 ML of 2C, 224, and 5-6 waste from 1947-1955 (Corbin et al. 2005). The estimated inventories of plutonium-239/240 and americium-241 are $262 \mathrm{Ci}$ and $6.57 \mathrm{Ci}$, respectively (Table 3.16).

Characterization of the 216-T-7 Tile Field is limited to geophysical logging of Wells 299-W10-69 and 299-W10-73 (DOE/RL 2007b). According to DOE/RL (2007b), the geophysical logging of these wells indicated a maximum plutonium-239 concentration of 29,000 pCi/g occurred in Well 299-W10-69

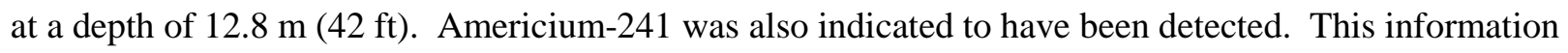
could not be verified from the original reference that was cited (DOE/RL/2000).

\subsubsection{Waste Site 241-T-106}

This tank farm leak event occurred during 1973. The waste designation is Sr-Cs Rec Org Wst (P2')_CSR and Sr-Cs Rec Org Wst aqu (P2)_BL with zero solids (Corbin et al. 2005). The estimated inventories of plutonium-239/240 and americium-241 are 2.43 Ci and 7.55 Ci, respectively (Table 3.16). 


\subsection{T Plant Zone}

Waste sites in the T Plant zone and associated quantities of plutonium, americium, and neptunium nuclides disposed (Ci) (decayed to January 1, 2001) are listed in Table 3.17. Only one site in this closure zone received plutonium-239 or americium-241 above 1.0 Ci (216-T-33).

Table 3.17. T Plant Zone Waste Sites and Associated Quantities of Plutonium, Americium, and Neptunium Nuclides Disposed (Ci), Decayed to January 1, 2001

\begin{tabular}{lrrrrrc}
\hline \multicolumn{1}{c}{ Waste Site } & Pu-238 & Pu-239 & Pu-240 & Pu-241 & Am-241 & Np-237 \\
\hline 200-W-9 & $<0.00$ & $<0.00$ & $<0.00$ & $<0.00$ & $<0.00$ & $<0.00$ \\
216-T-1 & $<0.00$ & 0.01 & $<0.00$ & 0.03 & $<0.00$ & $<0.00$ \\
216-T-2 & $<0.00$ & $<0.00$ & $<0.00$ & $<0.00$ & $<0.00$ & $<0.00$ \\
216-T-33 & 0.18 & 1.66 & 0.58 & 11.3 & $<0.00$ & $<0.00$ \\
216-T-8 & $<0.00$ & $<0.00$ & $<0.00$ & $<0.00$ & $<0.00$ & $<0.00$ \\
216-W-LWC & 0.03 & 0.25 & 0.07 & 1.96 & 0.01 & $<0.00$ \\
UPR-200-W-2 & $<0.00$ & 0.05 & $<0.00$ & $<0.00$ & 0.01 & $<0.00$ \\
UPR-200-W-21 & $<0.00$ & 0.06 & 0.01 & 0.02 & 0.05 & $<0.00$ \\
UPR-200-W-38 & $<0.00$ & 0.04 & $<0.00$ & 0.01 & 0.04 & $<0.00$ \\
UPR-200-W-98 & $<0.00$ & $<0.00$ & $<0.00$ & $<0.00$ & $<0.00$ & $<0.00$ \\
\hline
\end{tabular}

\subsubsection{Waste Site 216-T-33}

This site received 1.9 ML of decontamination waste and process condensate during 1963. This discharge is represented by B Plant decontamination stack drainage, decontamination waste, and UNH process condensate (Corbin et al. 2005). The estimated inventories of plutonium-239/240 and americium-241 are $2.24 \mathrm{Ci}$ and $<0.00 \mathrm{Ci}$, respectively (Table 3.17).

\subsection{Unassigned 200 Area 2}

Waste sites in the Unassigned 200 Area 2 and associated quantities of plutonium, americium, and neptunium nuclides disposed (Ci) (decayed to January 1, 2001) are listed in Table 3.18. Two sites in this area received plutonium-239 or americium-241 above $1.0 \mathrm{Ci}$.

\subsubsection{Waste Site UPR-200-W-102}

This UPR consisted of 28,993 L (7,660 gal) of 224 (BT2) waste and occurred in 1972 (Corbin et al. 2005). The estimated inventories of plutonium-239/240 and americium-241 are $4.01 \mathrm{Ci}$ and $<0.00 \mathrm{Ci}$, respectively (Table 3.18). 
Table 3.18. Unassigned 200 Area 2 Waste Sites and Associated Quantities of Plutonium, Americium, and Neptunium Nuclides Disposed (Ci), Decayed to January 1, 2001

\begin{tabular}{|c|c|c|c|c|c|c|}
\hline Waste Site & $\mathrm{Pu}-238$ & $\mathrm{Pu}-239$ & $\mathrm{Pu}-240$ & $\mathrm{Pu}-241$ & Am-241 & Np-237 \\
\hline 200-E-93 & $<0.00$ & $<0.00$ & $<0.00$ & $<0.00$ & $<0.00$ & $<0.00$ \\
\hline 200-E-94 & $<0.00$ & $<0.00$ & $<0.00$ & $<0.00$ & $<0.00$ & $<0.00$ \\
\hline 200-E-95 & $<0.00$ & $<0.00$ & $<0.00$ & $<0.00$ & $<0.00$ & $<0.00$ \\
\hline 200-E-97 & $<0.00$ & $<0.00$ & $<0.00$ & $<0.00$ & $<0.00$ & $<0.00$ \\
\hline 200-E-98 & $<0.00$ & $<0.00$ & $<0.00$ & $<0.00$ & $<0.00$ & $<0.00$ \\
\hline 200-E-99 & $<0.00$ & $<0.00$ & $<0.00$ & $<0.00$ & $<0.00$ & $<0.00$ \\
\hline 200-W-PP & $<0.00$ & $<0.00$ & $<0.00$ & $<0.00$ & $<0.00$ & $<0.00$ \\
\hline 200-W-72 & $<0.00$ & $<0.00$ & $<0.00$ & $<0.00$ & $<0.00$ & $<0.00$ \\
\hline 2101-M-Pond & $<0.00$ & 0.03 & 0.01 & 0.03 & $<0.00$ & $<0.00$ \\
\hline 216-A-16 & $<0.00$ & $<0.00$ & $<0.00$ & $<0.00$ & $<0.00$ & $<0.00$ \\
\hline 216-A-17 & $<0.00$ & $<0.00$ & $<0.00$ & $<0.00$ & $<0.00$ & $<0.00$ \\
\hline UPR-200-E-105 & $<0.00$ & $<0.00$ & $<0.00$ & $<0.00$ & 0.05 & $<0.00$ \\
\hline UPR-200-E-107 & $<0.00$ & $<0.00$ & $<0.00$ & $<0.00$ & $<0.00$ & $<0.00$ \\
\hline UPR-200-E-108 & $<0.00$ & $<0.00$ & $<0.00$ & $<0.00$ & $<0.00$ & $<0.00$ \\
\hline UPR-200-E-109 & $<0.00$ & $<0.00$ & $<0.00$ & $<0.00$ & $<0.00$ & $<0.00$ \\
\hline UPR-200-E-110 & $<0.00$ & $<0.00$ & $<0.00$ & $<0.00$ & $<0.00$ & $<0.00$ \\
\hline UPR-200-E-119 & $<0.00$ & $<0.00$ & $<0.00$ & $<0.00$ & $<0.00$ & $<0.00$ \\
\hline UPR-200-E-141 & $<0.00$ & $<0.00$ & $<0.00$ & $<0.00$ & $<0.00$ & $<0.00$ \\
\hline UPR-200-E-145 & $<0.00$ & $<0.00$ & $<0.00$ & $<0.00$ & $<0.00$ & $<0.00$ \\
\hline UPR-200-E-38 & $<0.00$ & 0.10 & 0.02 & 0.20 & 0.14 & 0.01 \\
\hline UPR-200-E-40 & $<0.00$ & $<0.00$ & $<0.00$ & $<0.00$ & $<0.00$ & $<0.00$ \\
\hline UPR-200-E-81 & 0.02 & 0.69 & 0.16 & 1.17 & 0.76 & $<0.00$ \\
\hline UPR-200-E-82 & $<0.00$ & 0.05 & 0.01 & 0.10 & 0.07 & $<0.00$ \\
\hline UPR-200-W-100 & $<0.00$ & $<0.00$ & $<0.00$ & $<0.00$ & $<0.00$ & $<0.00$ \\
\hline UPR-200-W-102 & 0.03 & 3.56 & 0.45 & 1.00 & $<0.00$ & $<0.00$ \\
\hline UPR-200-W-103 & 0.09 & 1.00 & 0.30 & 4.50 & 0.24 & $<0.00$ \\
\hline UPR-200-W-12 & $<0.00$ & $<0.00$ & $<0.00$ & $<0.00$ & $<0.00$ & $<0.00$ \\
\hline UPR-200-W-127 & $<0.00$ & $<0.00$ & $<0.00$ & $<0.00$ & $<0.00$ & $<0.00$ \\
\hline UPR-200-W-132 & $<0.00$ & $<0.00$ & $<0.00$ & $<0.00$ & $<0.00$ & $<0.00$ \\
\hline 241-SX-112 & $<0.00$ & $<0.00$ & $<0.00$ & $<0.00$ & $<0.00$ & $<0.00$ \\
\hline UPR-200-W-24 & $<0.00$ & 0.02 & $<0.00$ & 0.02 & 0.03 & $<0.00$ \\
\hline UPR-200-W-95 & $<0.00$ & $<0.00$ & $<0.00$ & $<0.00$ & $<0.00$ & $<0.00$ \\
\hline
\end{tabular}

\subsubsection{Waste Site UPR-200-W-103}

This UPR consisted of 300 L (79.3 gal) of RECUPLEX (Z2) org waste and occurred in 1971 (Corbin et al. 2005). The estimated inventories of plutonium-239/240 and americium-241 are $1.30 \mathrm{Ci}$ and $0.24 \mathrm{Ci}$, respectively (Table 3.18).

\subsection{Unassigned 200 Area}

Waste sites in the Unassigned 200 Area and associated quantities of plutonium, americium, and neptunium nuclides disposed (Ci) (decayed to January 1, 2001) are listed in Table 3.19. Two sites in this area received plutonium-239 or americium-241 above $1.0 \mathrm{Ci}$. 
Table 3.19. Unassigned 200 Area Waste Sites and Associated Quantities of Plutonium, Americium, and Neptunium Nuclides Disposed (Ci), Decayed to January 1, 2001

\begin{tabular}{lrrrrrr}
\hline \multicolumn{1}{c}{ Waste Site } & Pu-238 & Pu-239 & Pu-240 & Pu-241 & Am-241 & Np-237 \\
\hline 200-E-100 & $<0.00$ & $<0.00$ & $<0.00$ & $<0.00$ & $<0.00$ & $<0.00$ \\
200-E-103 & $<0.00$ & $<0.00$ & $<0.00$ & $<0.00$ & $<0.00$ & $<0.00$ \\
200-E-107 & $<0.00$ & $<0.00$ & $<0.00$ & $<0.00$ & $<0.00$ & $<0.00$ \\
200-E-25 & $<0.00$ & $<0.00$ & $<0.00$ & $<0.00$ & $<0.00$ & $<0.00$ \\
200-E-28 & $<0.00$ & $<0.00$ & $<0.00$ & $<0.00$ & $<0.00$ & $<0.00$ \\
200-E-4 & $<0.00$ & $<0.00$ & $<0.00$ & $<0.00$ & $<0.00$ & $<0.00$ \\
200-E-41 & $<0.00$ & $<0.00$ & $<0.00$ & $<0.00$ & $<0.00$ & $<0.00$ \\
200-E-54 & $<0.00$ & $<0.00$ & $<0.00$ & $<0.00$ & $<0.00$ & $<0.00$ \\
200-E-55 & $<0.00$ & $<0.00$ & $<0.00$ & $<0.00$ & $<0.00$ & $<0.00$ \\
200-E-56 & 0.01 & 0.45 & 0.10 & 0.60 & 21.4 & $<0.00$ \\
200-E-57 & 0.02 & 0.68 & 0.15 & 0.89 & 32.2 & $<0.00$ \\
200-E-60 & $<0.00$ & $<0.00$ & $<0.00$ & $<0.00$ & $<0.00$ & $<0.00$ \\
200-E-61 & $<0.00$ & $<0.00$ & $<0.00$ & $<0.00$ & $<0.00$ & $<0.00$ \\
200-E-62 & $<0.00$ & $<0.00$ & $<0.00$ & $<0.00$ & $<0.00$ & $<0.00$ \\
200-E-63 & $<0.00$ & $<0.00$ & $<0.00$ & $<0.00$ & $<0.00$ & $<0.00$ \\
200-E-64 & $<0.00$ & $<0.00$ & $<0.00$ & $<0.00$ & $<0.00$ & $<0.00$ \\
200-E-65 & $<0.00$ & $<0.00$ & $<0.00$ & $<0.00$ & $<0.00$ & $<0.00$ \\
200-E-67 & $<0.00$ & $<0.00$ & $<0.00$ & $<0.00$ & $<0.00$ & $<0.00$ \\
200-E-68 & $<0.00$ & $<0.00$ & $<0.00$ & $<0.00$ & $<0.00$ & $<0.00$ \\
200-E-69 & $<0.00$ & $<0.00$ & $<0.00$ & $<0.00$ & $<0.00$ & $<0.00$ \\
200-E-70 & $<0.00$ & $<0.00$ & $<0.00$ & $<0.00$ & $<0.00$ & $<0.00$ \\
200-E-71 & $<0.00$ & $<0.00$ & $<0.00$ & $<0.00$ & $<0.00$ & $<0.00$ \\
200-E-72 & $<0.00$ & $<0.00$ & $<0.00$ & $<0.00$ & $<0.00$ & $<0.00$ \\
200-E-73 & $<0.00$ & $<0.00$ & $<0.00$ & $<0.00$ & $<0.00$ & $<0.00$ \\
\hline & & & & &
\end{tabular}

\subsubsection{Waste Site 200-E-56}

The waste stream assigned to this site is assumed to be High-level Hot Semiworks waste based on surveillance information ( $>100 \mathrm{rad} / \mathrm{h}$ at $15 \mathrm{ft}$ ) and the timing of the loss presented in the WIDS (DOE/RL 2002a; Corbin et al. 2005). The estimated inventories of plutonium-239/240 and americium-241 are $0.55 \mathrm{Ci}$ and $21.4 \mathrm{Ci}$, respectively (Table 3.19). This waste release occurred in 1957.

\subsubsection{Waste Site 200-E-57}

The waste stream assigned to this site is assumed to be High-level Hot Semiworks waste based on surveillance information (>100 rad/h at $15 \mathrm{ft}$ ) and the timing of the loss presented in the WIDS (DOE/RL 2002a; Corbin et al. 2005). The estimated inventories of plutonium-239/240 and americium-241 are $0.83 \mathrm{Ci}$ and 32.2 Ci, respectively (Table 3.19). This waste release occurred in 1957. 


\subsection{Area}

\subsection{Unassigned 300 Area}

Waste sites in the Unassigned 300 Area and associated quantities of plutonium, americium, and neptunium nuclides disposed (Ci) (decayed to January 1, 2001) are listed in Table 4.1. Three sites in this area received plutonium-239 or americium-241 above 1.0 Ci. Note that each of these sites has been remediated as described in DOE/RL (2005).

Table 4.1. Unassigned 300 Area Waste Sites and Associated Quantities of Plutonium, Americium, and Neptunium Nuclides Disposed (Ci), Decayed to January 1, 2001

\begin{tabular}{lrrrrrr}
\hline \multicolumn{1}{c}{ Waste Site } & Pu-238 & Pu-239 & Pu-240 & Pu-241 & Am-241 & Np-237 \\
\hline $316-1$ & 0.19 & 3.23 & 0.80 & 10.0 & 0.15 & 0.02 \\
$316-2$ & 0.19 & 2.95 & 0.77 & 9.99 & 0.07 & 0.01 \\
$316-4$ & $<0.00$ & $<0.00$ & $<0.00$ & $<0.00$ & $<0.00$ & $<0.00$ \\
$316-5$ & 0.42 & 3.78 & 1.24 & 26.8 & $<0.00$ & 0.01 \\
\hline
\end{tabular}

\subsubsection{Waste Site 316-1}

The South Process Pond (site 316-1) received approximately 50,000 ML of fuel fabrication wastewater. This waste stream is represented as a combination of cladding waste, decontamination waste, and cooling water (Corbin et al. 2005). The estimated inventories of plutonium-239/240 and americium-241 are $4.03 \mathrm{Ci}$ and $0.15 \mathrm{Ci}$, respectively (Table 4.1). The site operated 1944-1975.

\subsubsection{Waste Site 316-2}

The North Process Pond (site 316-2) received approximately 37,000 ML of fuel fabrication wastewater. This waste stream is represented as a combination of cladding waste, decontamination waste, and cooling water (Corbin et al. 2005). The estimated inventories of plutonium-239/240 and americium 241 are $3.72 \mathrm{Ci}$ and $0.07 \mathrm{Ci}$, respectively (Table 4.1). The site operated from 1949-1975.

\subsubsection{Waste Site 316-5}

The 300 Area Process Trenches (site 316-5) received more than 36,000 ML of fuel fabrication process cooling water. This waste stream is represented using PUREX process cooling water, and the total volume disposed to the site was linearized to provide annual discharge volumes (Corbin et al. 2005). The estimated inventories of plutonium-239/240 and americium-241 are 5.02 $\mathrm{Ci}$ and $<0.00 \mathrm{Ci}$, respectively (Table 4.1). The site operated 1975-1985. 


\subsection{Summary and Conclusions}

A review of transuranic radionuclide contamination in sediments and groundwater at the DOE Hanford Site was conducted. The review focused primarily on plutonium-239/240 and americium-241; however, other transuranic nuclides were discussed as well, including neptunium-237, plutonium-238, and plutonium-241. The scope of the review included liquid process wastes intentionally disposed to constructed waste disposal facilities such as trenches and cribs, burial grounds, and unplanned releases to the ground surface. The review did not include liquid wastes disposed to tanks or solid wastes disposed to burial grounds.

It is estimated that over $11,800 \mathrm{Ci}$ of plutonium-239, 28,700 $\mathrm{Ci}$ of americium-241, and $55 \mathrm{Ci}$ of neptunium-237 have been disposed as liquid waste to the near-surface environment at the Hanford Site. Despite the very large quantities of transuranic contaminants disposed to the vadose zone at Hanford, only minuscule amounts have entered the groundwater. Currently, no wells onsite exceed the DOE-derived concentration guide for plutonium-239/240 (30 pCi/L) or any other transuranic contaminant in filtered samples. The DOE-derived concentration guide was exceeded by a small fraction in unfiltered samples from one well (299-E28-23) in recent years (35.4 and 40.4 pCi/L in FY 2006).

The primary reason that disposal of these large quantities of transuranic radionuclides directly to the vadose zone at the Hanford Site has not resulted in widespread groundwater contamination is that under the typical oxidizing and neutral to slightly alkaline $\mathrm{pH}$ conditions of the Hanford vadose zone, transuranic radionuclides (plutonium and americium in particular) have a very low solubility and high affinity for surface adsorption to mineral surfaces common within the Hanford vadose zone. Other important factors are the fact that the vadose zone is typically very thick (hundreds of feet) and the net infiltration rate is very low due to the desert climate.

In some cases where transuranic radionuclides have been co-disposed with acidic liquid waste, transport through the vadose zone for considerable distances has occurred. For example, at the 216-Z-9 Crib, plutonium-239 and americium-241 have moved to depths in excess of $36 \mathrm{~m}$ (118 ft) bgs. Acidic conditions and the presence of possible complexants could increase the solubility of these contaminants and reduce adsorption to mineral surfaces. Subsequent neutralization of the acidity by naturally occurring calcite in the vadose zone (particularly in the Cold Creek unit) appears to have effectively stopped further migration.

The vast majority of transuranic contaminants disposed to the vadose zone on the Hanford Site (10,200 Ci [86\%] of plutonium-239; 27,900 Ci [97\%] of americium-241; and 41.8 Ci [78\%] of neptunium-237) were disposed in sites within the PFP closure zone. This closure zone is located within the 200 West Area (see Figures 1.1 and 3.1). Other closure zones with notably high quantities of transuranic contaminant disposal include the T Farm zone with $408 \mathrm{Ci}$ (3.5\%) plutonium-239, the PUREX zone with $330 \mathrm{Ci}$ (2.8\%) plutonium-239, 200-W Ponds zone with 324 Ci (2.8\%) plutonium-239, B Farm zone with $183 \mathrm{Ci}$ (1.6\%) plutonium-239, and the REDOX zone with $164 \mathrm{Ci}(1.4 \%)$ plutonium-239. 
Characterization studies for most of the sites reviewed in the document are generally limited. The most prevalent characterization methods used were geophysical logging methods. Characterization of a number of sites included laboratory analysis of borehole sediment samples specifically for radionuclides and other contaminants, as well as geologic and hydrologic properties. In some instances, more detailed research level studies were conducted. Results of these studies were summarized in the document. 


\subsection{References}

Adam WJ and CS Cearlock. 1999. Preliminary Hazard Classification for the 200-CW-1 Operable Unit Sampling and Characterization Activities to be Conducted at the 216-B-3-3 Ditch, the 216-B-2-2 Ditch, the 216-B-3 Pond, and the Gable Mountain Pond. BHI-01281, Rev. 0., Bechtel Hanford, Inc., Richland, Washington.

Agnew SF, J Boyer, RA Corbin, TB Duran, JR FitzPatrick, KA Jurgensen, TP Ortiz, and BL Young. 1997. Hanford Tank Chemical and Radionuclide Inventories: HDW Model Rev. 4. LA-UR-96-3860, Los Alamos National Laboratory, Los Alamos, New Mexico.

Ambalam T and DJ Watson. 2004. Effective Environmental Compliance Strategy for the Cleanup of K Basins at Hanford Site, Washington. HNF-22567-FP, Rev. 0, Fluor Hanford, Inc., Richland, Washington.

BHI. 1995. DNAPL Investigation Report. BHI-00431, Rev. 0, Bechtel Hanford, Inc., Richland, Washington.

Brown RE and HG Ruppert. 1948. Underground Waste Disposal at Hanford Works. HW-9671, General Electric, Richland, Washington.

Buesseler KO, M Dai, D Repeta, JF Wacker, and JM Kelly. 2003. Speciation, Mobility and Fate of Actinides in the Groundwater at the Hanford Site. DOE/ER/14733, U.S. Department of Energy, Washington, D.C.

Buswell and Sexton. 2008. Borehole Summary Report for the 216-A-30 Crib Characterization Borehole C5941 in the 200-SC-1 Operable Unit. SGW-38048, Rev. 0, Fluor, Richland, Washington

Cantrell KJ, KN Geiszler, and BW Arey. 2008. Plutonium Mobility Studies: 216-Z-9 Trench Sample Analysis Results. PNNL-17839, Pacific Northwest National Laboratory, Richland, Washington.

Cary A. March 29, 2009. “DOE May Shrink Hanford’s Active Area to 10 Square Miles.” Tri-City Herald, Richland, Washington.

Chronister GB and PM Knollmeyer. 2006. Source Term Remediation and Demolition Strategy for the Hanford K-Area Spent Fuel Basins. KBC-29270-FP, Rev. 0, Fluor, Richland, Washington.

CNN 65632-86-095. 1986. Alpha Contamination in the Z-1/Z-1A Crib Complex. Internal Letter to VW Hall from RC Routson, Rockwell International, Richland, Washington, September 23.

Corbin RA, BC Simpson, MJ Anderson, WF Danielson III, JG Field, TE Jones, and CT Kincaid. 2005. Hanford Soil Inventory Model, Rev. 1. RPP-26744, CH2M HILL Hanford Group, Richland, Washington.

Cowen CE, EA Jenne, DE Robertson, DM Nelson, and KH Abel. 1985. Transuranic Chemical Species in Groundwater: Final Report. PNL-5263, Pacific Northwest Laboratory, Richland, Washington. 
Cushing CE and DG Watson. 1974. Aquatic Studies of Gable Mountain Pond. BNWL-1884, Pacific Northwest Laboratories, Richland, Washington.

Dai M, KO Buesseler, and SM Pike. 2005. "Plutonium in Groundwater at the 100K-Area of the U.S. DOE Hanford Site. Journal of Contaminant Hydrology 76:167-189.

Deford DH, RW Carpenter, and MW Einan. 1994. 300-FF-2 Operable Unit Technical Baseline Report. BHI-00012, Rev. 00, Bechtel Hanford, Inc., Richland, Washington.

Diediker LP. 1999. Radionuclide Inventories of Liquid Waste Disposal Sites on the Hanford Site. HNF-1744, Fluor Daniel Hanford, Inc., Richland, Washington.

DOE/GJO. 2002. 216-B-8 Crib and Adjacent Sites Waste Site Summary Report. GJO-2002-343-TAR, U.S. Department of Energy, Grand Junction Office, Grand Junction, Colorado.

DOE/RL. 2000. 200-TW-1 Scavenged Waste Group Operable Unit and 200-TW-2 Tank Waste Group Operable Unit RI/FS Work Plans. DOE/RL-2000-38, Rev. 0, U.S. Department of Energy, Richland Operations Office, Richland, Washington.

DOE/RL. 2002a. Waste Information Data System (WIDS), General Summary Report, Hanford Site Database, queried variously from September to December, 2002, Hanford Local Area Network server APSQL12, http://www2.rl.gov/WIDS (DOE-RL 2002). U.S. Department of Energy, Richland Operations Office, Richland, Washington.

DOE/RL. 2002b. Chemical Laboratory Waste Group Operable Unit RI/FS Work Plan. DOE/RL-2001-66, U.S. Department of Energy, Richland Operations Office, Richland, Washington.

DOE/RL. 2003. Feasibility Study for the 200-TW-1 Scavenged Waste Group, the 200-TW-2 Tank Waste Group, and the 200-PW-5 Fission-Product Rich Waste Group Operable Units. DOE/RL-2003-64, Draft A, U.S. Department of Energy, Richland Operations Office, Richland, Washington.

DOE/RL. 2004. Remedial Investigation Report for the 200-PW-2 Uranium-Rich Process Waste Group and the 200-PW-4 General Process Condensate Group Operable Units. DOE/RL-2004-25, Draft A, U.S. Department of Energy, Richland Operations Office, Richland, Washington.

DOE/RL. 2005. 300-FF-1 Operable Unit Remedial Action Report. DOE/RL-2004-74, Rev. 0, U.S. Department of Energy, Richland Operations Office, Richland, Washington.

DOE/RL. 2006. Remedial Investigation Report for the 200-LW-1 (300 Area Chemical Laboratory Waste Group), and 200-LW-2 (200 Area Chemical Laboratory Waste Group) Operable Units. DOE/RL-2005-61, Draft A, U.S. Department of Energy, Richland Operations Office, Richland, Washington.

DOE/RL. 2007a. Remedial Investigation Report for the Plutonium/Organic-Rich Process Condensate/ Process Waste Group Operable Unit: Includes the 200-PW-1, 200-PW-3, and 200-PW-6 Operable Units. DOE/RL-2006-51, Rev. 0, U.S. Department of Energy, Richland Operations Office, Richland, Washington. 
DOE/RL. 2007b. Site-Specific Field-Sampling Plans for the 216-B-7A\&B Crib, 216-B-8 Crib and Tile Field, 216-T-3 Injection/Reverse Well, 216-T-5 Trench, 216-T-6 Cribs, 216-T-7 Crib and Tile Field, 216-T-15 Trench, and 216-T-32 Crib in the 200-TW-2 Operable Unit Addendum 4. DOE/RL-2007-02VOL II-ADD 4, Revision 0, U.S. Department of Energy, Richland Operations Office, Richland, Washington.

DOE/RL. 2007c. Supplemental Remedial Investigation/Feasibility Study Work Plan for the 200 Areas Central Plateau Operable Units, Rev. 0, Vol. II, Site-Specific Field-Sampling Plan Addenda. DOE/RL2007-02-VOL II, Revision 0, U.S. Department of Energy, Richland Operations Office, Richland, Washington.

DOE/RL. 2008. Hanford Site Groundwater Monitoring for Fiscal Year 2007. DOE/RL-2008-01, U.S. Department of Energy, Richland Operations Office, Richland, Washington.

Dorian JJ and VR Richards. 1978. Radiological Characterization of the Retired 100 Area. UNI-946, UNC Nuclear Industries, Inc., Richland, Washington

Fecht KR, GV Last, and KR Price. 1977. Evaluation of Scintillation Probe Profiles from 200 Area Crib Monitoring Wells. ARH-ST-156, Atlantic Richfield Hanford Company, Richland, Washington.

Field JG and TE Jones. 2005. Tank Farm Vadose Zone Contamination: Volume Estimates for Risk Assessments. RPP-23405, Rev. 0, CH2M HILL Hanford Group, Richland, Washington.

Fluor Hanford, Inc. 2008. 200-PW-1 Operable Unit Report on Step II Sampling and Analysis of the Dispersed Carbon Tetrachloride Vadose-Zone Plume. SGW-33829, Flour Hanford, Inc., Richland, Washington.

Fluor Hanford. 2005. 200-PW-2 Operable Unit Borehole Summary Report for the 216-S-7 Crib. D\&D-25034, Rev. 0, Fluor Hanford, Richland, Washington.

Gerber MS. 2008. Fluor Hanford Decommissioning Update: Spring 2008. HNF-37499, Rev. 0, Fluor Hanford, Inc., Richland, Washington.

Haney WA and CE Linderoth. 1959. Exploratory Field Study of a Ground Waste Disposal Facility. HW-60115, General Electric Company, Richland, Washington.

Hanson GL, JD Anderson, GR Kiel, BJ McMurray, and NP Nisick. 1973. Input and Decayed Values of Radioactive Liquid Wastes Discharged to the Ground in the 200 Areas Through 1971. ARH-2761, Atlantic Richfield Hanford Company, Richland, Washington.

Higley BA, DE Place, RA Corbin, and BC Simpson. 2004. Hanford Defined Waste Model, Rev. 5. RPP-19822, Rev. 0, CH2M HILL Hanford Group, Inc., Richland, Washington.

Johnson VG, CJ Chou, and JW Lindberg. 1995. Groundwater Monitoring and Assessment Plan for the 100-K Area Fuel Storage Basins. WHC-SD-EN-AP-174, Rev. 0, Westinghouse Hanford Company, Richland, Washington. 
Kasper RB. 1982. 216-Z-12 Transuranic Crib Characterization: Operational History and Distribution of Plutonium and Americium. RHO-ST-44, Rockwell Hanford Operations, Richland, Washington.

Kincaid CT, RW Bryce, and JW Buck. 2004. Technical Scope and Approach for the 2004 Composite Analysis of Low Level Waste Disposal at the Hanford Site. PNNL-14372, Pacific Northwest National Laboratory, Richland, Washington.

Last GV, DW Duncan, MJ Graham, MD Hall, VW Hall, DS Landeen, JG Leitz, and RM Mitchell. 1994. 216-U-10 Pond and 216-Z-19 Ditch Characterization Studies. WHC-EP-0707, Westinghouse Hanford Company, Richland, Washington.

Lindberg M. 2008. Geochemical Study of Grab Samples Collected From the 216-A-30 Crib. PNNL-61191, Pacific Northwest National Laboratory, Richland, Washington.

Lindenmeier CW, RJ Serne, BN Bjornstad, GV Last, DC Lanigan, MJ Lindberg, RE Clayton, VL LeGore, IV Kutnyakov, SR Baum, KN Geiszler, MM Valenta, and TS Vickerman. 2002. Characterization of Vadose Zone Sediment: Borehole C3103 Located in the 216-B-7A Crib Near the B Tank Farm. PNNL-14128, Pacific Northwest National Laboratory, Richland, Washington.

Ludowise JD. 1999. Data Summary Report for 116-N-1 and 116-N-3 Facility Soil Sampling to Support Remedial Design. BHI-01271, Bechtel Hanford Inc., Richland Washington.

Maxfield HL. 1979. Handbook 200 Area Waste Sites. RHO-CD-673, Vols. I-III, Rockwell Hanford Operations, Richland, Washington.

Neck V, M Altmaier, A Seibert, JI Yun, CM Marquardt, and T Fanghänel. 2007a. "Solubility and Redox Reactions of $\mathrm{Pu}(\mathrm{IV})$ Hydrous Oxides: Evidence for the Formation of $\mathrm{PuO}_{2+\mathrm{x}}(\mathrm{s}$,hyd).” Radiochimica Acta 95:193-207.

Neck V, M Altmaier, and T Fanghänel. 2007b. “Solubility of Plutonium Hydroxides/Hydrous Oxides Under Reducing Conditions and in the Presence of Oxygen.” Comptes rendus Chimie 10:959-977.

Price SM, RB Kasper, MK Additon, RM Smith, and GV Last. 1979. Distribution of Plutonium and Americium Beneath the 216-Z-1A Crib: A Status Report. RHO-ST-17, Rockwell Hanford Operations, Richland, Washington.

Rhodes DW. 1956. Investigation of the Effect of Waste Disposal Procedure Modification of Disposal of D-2 Waste to the Ground. HW-48356, General Electric Company, Richland, Washington.

Serne RJ, GV Last, GW Gee, HT Schaef, DC Lanigan, CW Lindenmeier, RE Clayton, VL LeGore, RD Orr, MJ O’Hara, CF Brown, DS Burke, AT Owen, IV Kutnyakov, TC Wilson, KB Wagnon, BA Williams, and DS Burke. 2002. Characterization of Vadose Zone Sediment: Borehole 41-09-39 in the S-SX Waste Management Area. PNNL-13757-3, Pacific Northwest National Laboratory, Richland, Washington.

Smith AE. 1973. Nuclear Reactivity Evaluations of 216-Z-9 Enclosed Trench. ARH-2915, Atlantic Richfield Hanford Company, Richland, Washington. 
Smith RM. 1980. 216-B-5 Reverse Well Characterization Study. RHO-ST-37, Rockwell Hanford Operations, Richland, Washington.

Stoller. 2006. “Contract No. 30475-1, Stoller Geophysical Log Results in the 216-A-30 Trench.” S. M. Stoller Corporation, Broomfield, Colorado.

Todd ME and C Trice. 2002. Borehole Summary Report for Boreholes C3101 and C3104, and Drive Casings C3340, C3341, C3342, C3343, and C3344, in the 216-B-38 Trench and 216-B-7A Crib, 200-TW-2 Tank Waste Group Operable Unit. BHI-01607, Rev. 0, Bechtel Hanford, Inc., Richland, Washington.

Van Luik AE and RM Smith. 1982. 216-S-1 and S-2 Mixed Fission Product Crib Characterization Study. RHO-ST-39, Rockwell Hanford Operations, Richland, Washington.

Weimer WC. 1978. Isolation of Plutonium Physical-Chemical States from Natural Waters. PNL-2672, Pacific Northwest Laboratory, Richland, Washington.

Williams BA. 2008. Description of Work for the Installation of Five Boreholes at the 200-PW-2/4 Operable Unit Waste Sites 216-A-5 Crib and 216-S-1\&2 Cribs, FY 2008. SGW-37437, Rev. 0, Fluor Hanford, Inc., Richland, Washington.

Wolff JH. 1952. Calculation Constants Used by Regional Survey, Part 2, Alpha Sample Counting Rate Conversion Factors. HW-23769, General Electric Company, Richland, Washington. 


\section{Distribution}

No. of

Copies

\section{OFFSITE}

S. D. Conradson

Los Alamos National Laboratory

P.O. Box 1663

Los Alamos, NM 87545

D. I. Kaplan

Savannah River National Laboratory

Savannah River Site

Aiken, SC 29808

\section{ONSITE}

DOE Richland Operations Office
A. C. Tortoso
A6-38

2 CH2M HILL Plateau Remediation

Company

S. M. Joyce

H8-43

V. J. Rohay

H8-15

Fluor Federal Services/CH2M HILL

Plateau Remediation Company

J. L. Jensen

H8-51

Vista/CH2M HILL Plateau Remediation Company

K. Moser

H8-15
No. of

Copies

\section{ONSITE}

12 Pacific Northwest National Laboratory
K. J. Cantrell (3)
K6-81
A. R. Felmy (5)
K8-96
J. K. Fredrickson
P7-54
G. V. Last
K6-81
J. M. Zachara
K8-96
Information Release Office 


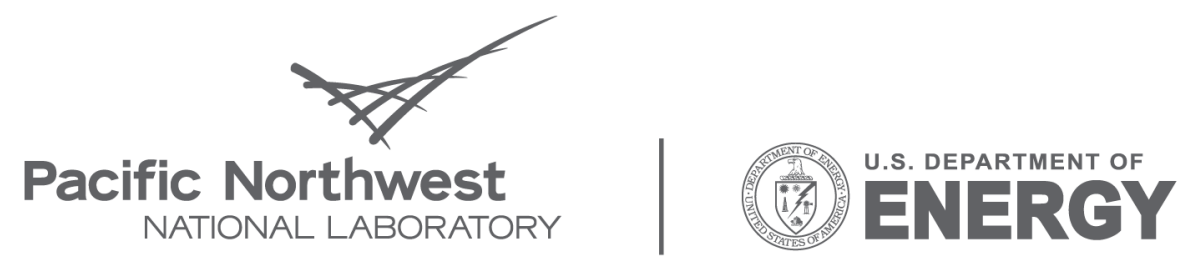

Proudly Operated by Battelle Since 1965

902 Battelle Boulevard

P.O. Box 999

Richland, WA 99352

1-888-375-PNNL (7665)

www.pnl.gov 